University of Nebraska - Lincoln

DigitalCommons@University of Nebraska - Lincoln

Agronomy \& Horticulture -- Faculty Publications

Agronomy and Horticulture Department

10-1936

\title{
Effects of the Great Drought on the Prairies of lowa, Nebraska, and Kansas
}

J. E. Weaver

University of Nebraska-Lincoln

F. W. Albertson

University of Nebraska-Lincoln

Follow this and additional works at: https://digitalcommons.unl.edu/agronomyfacpub

Part of the Plant Sciences Commons

Weaver, J. E. and Albertson, F. W., "Effects of the Great Drought on the Prairies of lowa, Nebraska, and Kansas" (1936). Agronomy \& Horticulture -- Faculty Publications. 456.

https://digitalcommons.unl.edu/agronomyfacpub/456

This Article is brought to you for free and open access by the Agronomy and Horticulture Department at DigitalCommons@University of Nebraska - Lincoln. It has been accepted for inclusion in Agronomy \& Horticulture -Faculty Publications by an authorized administrator of DigitalCommons@University of Nebraska - Lincoln. 


\title{
EFFECTS OF THE GREAT DROUGHT ON THE PRAIRIES OF IOWA, NEBRASKA, AND KANSAS *1
}

\author{
J. E. Weaver and F. W. Albertson \\ The University of Nebraska
}

The response of prairie vegetation of eastern Nebraska during the great drought of 1934 has been described (Weaver, Stoddart, and Noll, '35). The purpose of the present study was to determine the results of the drought during the following year. The work has been extencled to include the mixed prairie of west central Kansas.

\section{Studies in Tall-Grass Prairie}

The most severe drought ever recorded in the prairies of eastern Nebraska, western Iowa, and Kansas occurred during 1934. Studies of water content of soil throughout many growing seasons show clearly that the drought came on gradually during a period of 3 or 4 years. Water content of the upland was slowly depleted and by July 30,1934, no water to a depth of 4 feet was available for growth. During July of this abnormally hot growing season, the average weekly maximum daily temperature varied from $98^{\circ}$ to $111^{\circ} \mathrm{F}$. The average weekly minimum daily humidity varied from 15 to 22 per cent. During certain afternoons the humidity was only 3 to 5 per cent. Drought swept from hilltops down the slopes into mesic and hydric ravines. Wilting, drying, and death of vegetation were not due alone to high temperatures and low humidities but primarily to low water content of soil, since plants in watered areas thrived.

Complete records of environmental factors in the prairie are being published elsewhere (Noll, '35) ; water content of soil available for growth before, during, and at the close of the drought are shown in figure 1. Hygroscopic coefficients of the Carrington silt loam, which ranged between 10.8 and 13.4 per cent at the several depths, were used as the approximate point of nonavailability. Samples from which the data were compiled were taken from a typical upland, little-bluestem prairie on a gentle south slope near Lincoln. The abundant water supply in early spring in the first 2 feet was greatly reduced during May and entirely depleted by midsummer. The moderate to

* Contribution from the Department of Botany, University of Nebraska, no. 100.

1 This research was made possible by a grant-in-aid for studies on drought to the senior author from the National Research Council.

The publication of the excess pages and illustrations in this article has been made possible by funds other than those of the Ecological Society of America. 
small reserves of the deeper soil in spring were likewise greatly reduced in June and entirely depleted in August to a depth of 4 feet, the deeper soil to 6 feet retaining less than 2 per cent available moisture. Drought continued during the winter and was not ameliorated until the following April. By June, subsoil moisture had been replenished to a depth of 6 feet. Below $\sigma$ feet depth moisture was constantly available throughout the drought, but in small amounts only.

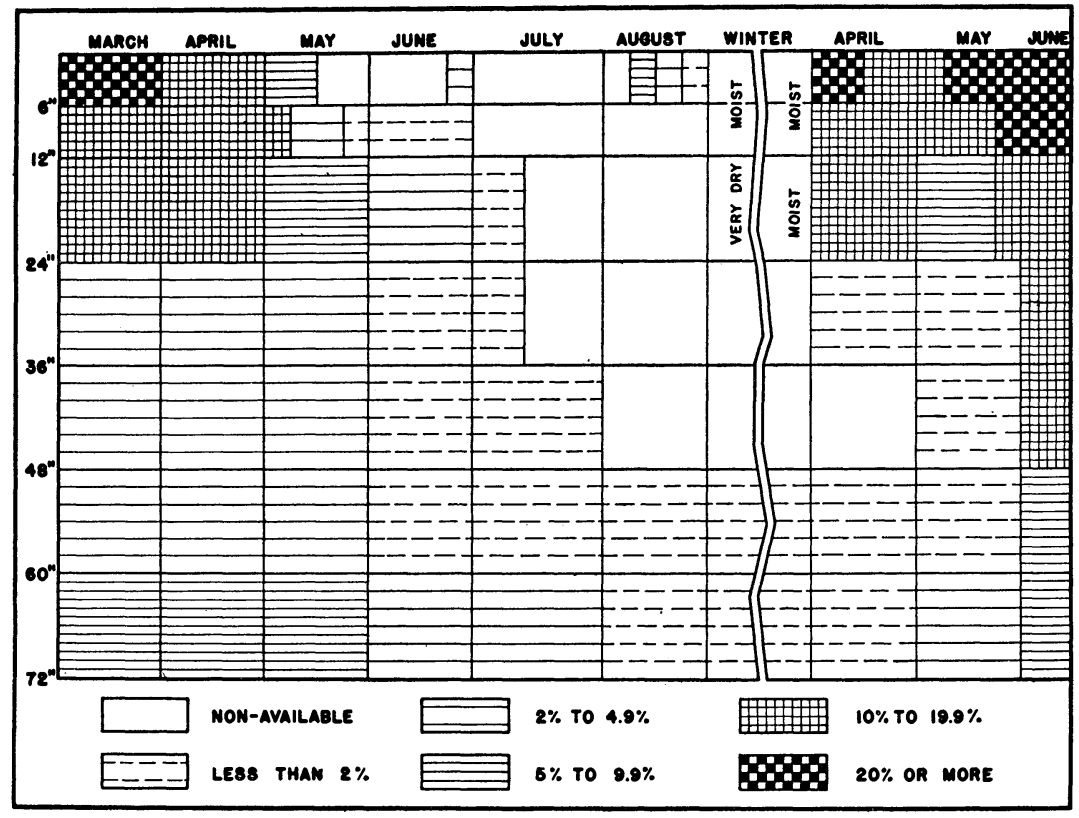

FIG. 1. Available water content of prairie soil near Lincoln, Nebraska, at the several depths to 6 feet, from March, 1934, to June, 1935.

A close relationship was found between root depth of most prairie grasses and resistance to drying. Among the forbs, resistance to drought was closely correlated with root extent. Species with root systems penetrating 8 to 20 feet into the moist subsoil were little affected. Many other species wilted and dried. This is in accord with the investigation of Nedrow ('36) who found a direct relationship between the amount of growth of tops of important prairie grasses and the depth at which water was available for absorption. When water was available only at a depth of 3 or 4 feet, some development of tops still occurred. Certain forbs grew normally when water was available only at depths below 3 to 5 feet. 


\section{Prairies NeAr Lincoln}

Destruction wrought by drought in a group of prairies near Lincoln varied in degree but is well represented by the following descriptive and quantitative studies. $^{2}$

\section{Valparaiso prairie}

A prairie one-half square mile in area covers hilly land 3 miles west of Valparaiso (fig. 2). In 1930, Andropogon scoparius, little bluestem, dom-

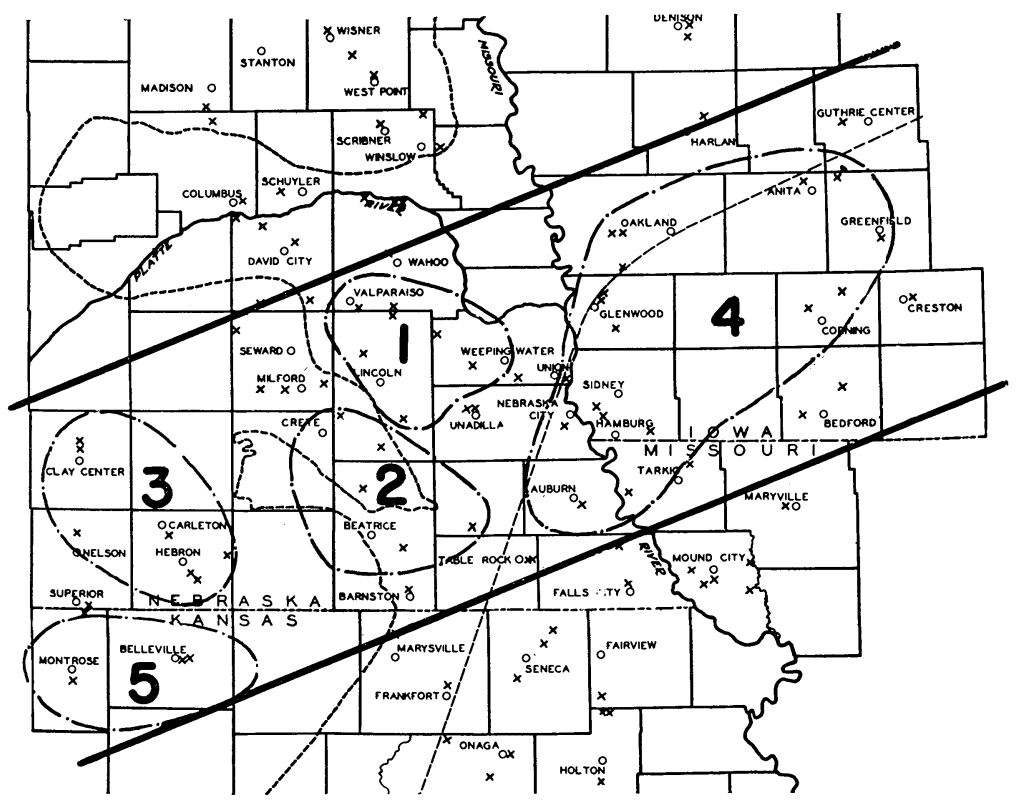

FIG. 2. Outline map showing groups of prairies (marked $x$ ) studied (1) about Lincoln, (2) south of Lincoln, (3) southwest of Lincoln, (4) in western Iowa and southeastern Nebraska, and (5) in north-central Kansas. The subdivisions are counties and the circles indicate towns or cities. The broken line across the southeastern part indicates approximately the isohyet of 32 inches. The tortuous line from north to south separates the Prairyerths on the east from the Blackerths on the west.

inated the hilltops, forming 60 to 90 per cent of the vegetation. A. furcatus, big bluestem, occurring in small tufts or as individual plants, frequently to the extent of 10 to 15 per square meter, was found in every one of a score of quadrats. Poa pratensis, bluegrass, was present to the extent of 1 to 3 per

2 Prairies used for drought studies were the same as those employed in the investigations on "The Prairie" (Weaver and Fitzpatrick, '34). Since each of the prairies was earlier studied and described as a unit, the changes wrought by drought were readily determined. For purposes of comparison, a condensed statement of former conditions is sometimes included in this paper. 
cent; Sorghastrum nutans, Indian grass, occurred in small amounts as did also Bouteloua curtipendula and $B$. gracilis. Carex pennsylvanica was well represented. Alternes of Sporobolus heterolepis with little and big bluestem, Koeleria cristata, and bluegrass were common on the drier ridges. A good understory of minor grasses and forbs was common throughout. The basal cover varied from 11 to 18 per cent. Halfway down the north-facing slopes and still lower on the south and southwest hillsides big bluestem increased to 30 to 40 per cent, blue grama and other xeric species disappeared. On lower slopes and in ravines, big bluestem constituted 80 to 90 per cent of the cover; Panicum virgatum, Indian grass, and bluegrass were the other important species.

This prairie had been visited annually. Few noticeable changes occurred until 1933, but marked ones during 1934. In the early summer of 1935, quadrats on the hilltops, where drought had been most severe, showed a loss of 45 per cent of the basal cover. A large series of random quadrats gave a reduction of 20 per cent over the upper north slope. Careful estimates of losses for the highest lands varied from 10 per cent where damage was least to 25 for the area as a whole. On lower midslopes average losses decreased to 12 per cent, and on still lower areas only traces of destruction by drought were found.

Little bluestem, bluegrass, and the interstitial Panicum scrionervanum and $P$. wilcoxianum had suffered most. Sporobolus heterolepis, dropseed, had also been much damaged, and dead bases and rhizomes of big bluestem, Indian grass, and most other species were also readily found. Seedlings of Koeleria cristata, June grass, were abundant, as were also those of Kuhnia glutinosa and Erigeron ramosus. Blue grama grass and Carex pennsylvanica were spreading and Agropyron smithii was also readily invading the areas bared by the death of the bluestems and other grasses. Wheat grass often grew in the dead bunches of these dominants. Antennaria campestris, young plants of Helianthus rigidus and Solidago glaberrima, and various other sha1lowly rooted plants had nearly all been killed by the drought.

Silene antirrhina was common everywhere as were also small amounts of Lepidium virginicum. ${ }^{3}$ Aster multiflorus, likewise profiting by the thinning of the prairie sod, had spread rapidly by underground parts. Bulbous species and others with fleshy underground parts or very deep root systems had usually sustained the smallest losses. On lower slopes and level ground, losses were similar in character but much smaller in amount.

\section{Belmont prairie}

The 160-acre Belmont prairie at Lincoln is representative of numerous others of eastern Nebraska. The little-bluestem type, alternating with Stipa spartea, needle grass, on the ridges and big bluestem in the ravines, has been

${ }^{3}$ Probably L. densiflorum in part. 
described (Weaver and Thiel, '17). Losses from drought varied greatly with slope and exposure as well as with degree of burning, frequency of mowing, etc. In general, any protection afforded by dead cover was distinctly favorable to both soil and vegetation. Plants on unburned portions of the prairie mowed but once annually, which is the usual practice, suffered least.

A large series of quadrats for determination of basal cover in 1930 to 1932 gave an average of 9.2 per cent but in 1935 the basal cover in the same area was reduced to 5.9 per cent, a loss of 36 per cent (figs. 3 and 4 ).

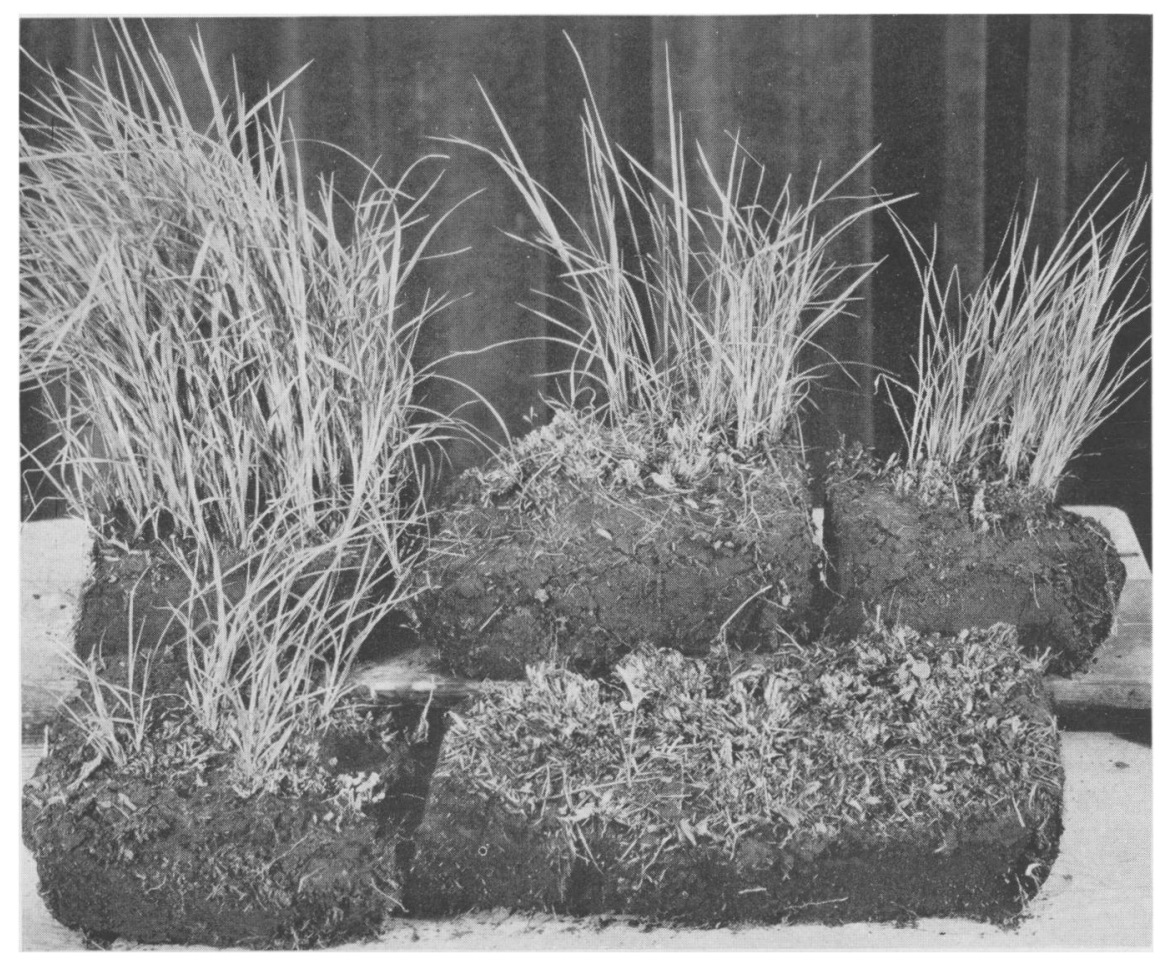

FIG. 3. Selected sods of Andropogon scoparius on June 19, 1935, showing various degrees of loss by drought from 0 (upper left where the grass is 16 inches tall) to 100 per cent (lower right). Note the retarded development where most of the bunch died.

The major losses were of the nature of "holes" or openings in the prairie cover, a condition greatly emphasized because of the unusual development of the foliage early in 1935 (figs. 5 and 6). Superficially the prairie appeared normal-to appreciate the losses one had to penetrate the foliage and study the basal cover. In the moderately affected areas, spaces bare of living plants were more or less isolated. Each, however, bore its toll of dead crowns of little bluestem or dropseed, rhizomes of big bluestem and Indian grass, usually exposed by erosion of wind or water, the paler stem-bases of needle grass and bluegrass, or remnants of other species. 
Often these openings were marked by dense patches of annuals or shortlived perennials. Most.important of these were Lepidium virginicum, Tragopogon pratensis, Silene antirrhina, Specularia perfoliata, Festuca octofiora, and Erigeron ramosus (figs. 7 and 8 ). But many such areas remained bare throughout the entire summer. These openings in the grass cover were conspicuous throughout the growing season. A dry spring retarded early growth, a moist early summer promoted unusual development of established plants which caused so dense a shade as to inhibit development of seedlings. In fact,

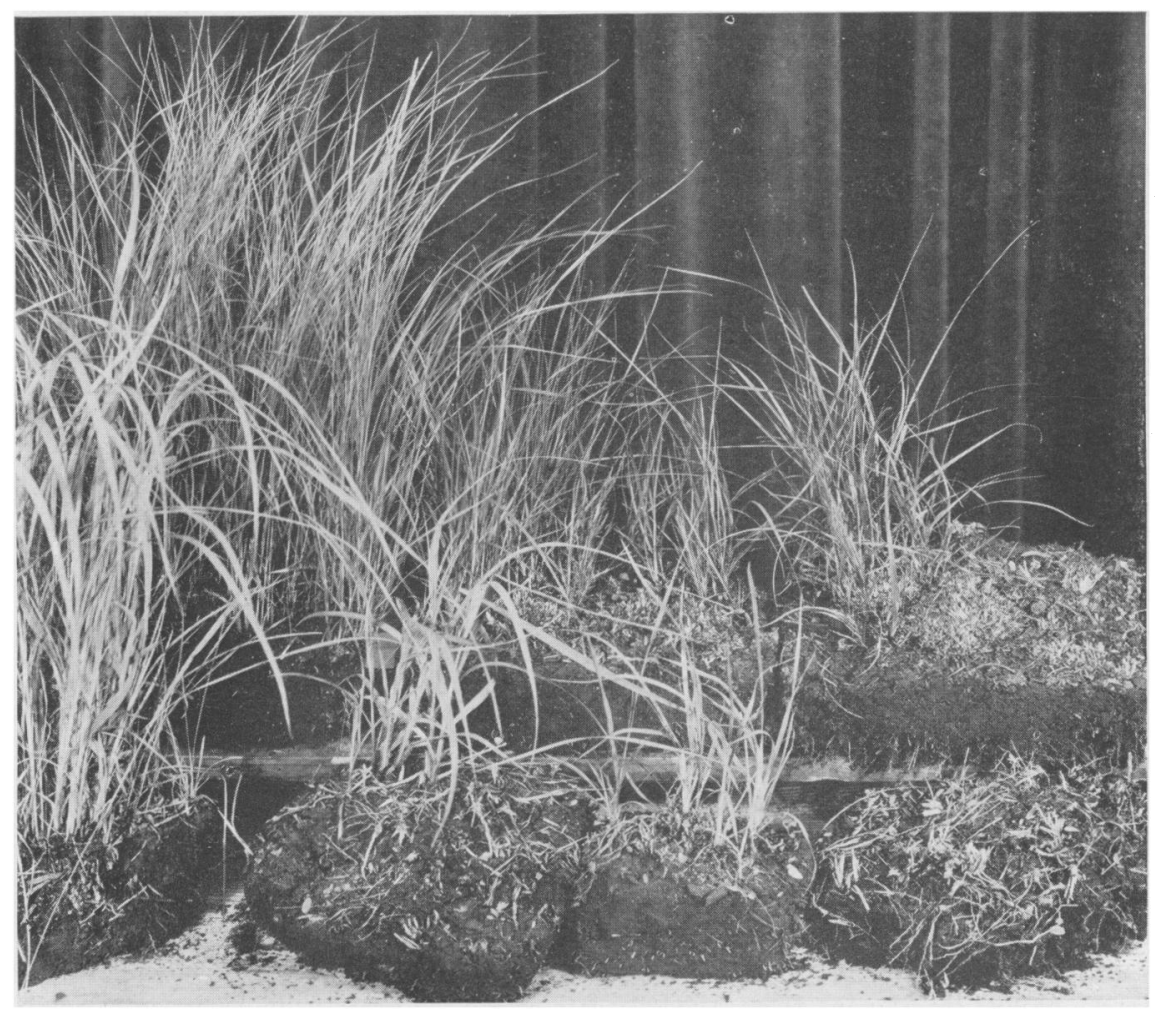

IiIg. 4. Normal development of Sporobolus heterolepis (upper row) and Andropogon furcatus (lower row) on left, and progressive destruction by drought.

with a loss of one-third of the basal cover, the cover of foliage appeared nearly as great as during a normal year for growth. The weedy annuals, where they had invaded, all died in June but remained intact almost throughout the summer.

Where drought was more severe the open spaces were more plentiful and formed a very irregular network of unoccupied soil surface. This was beautifully illustrated in many alternes of Stipa. Often most of the smaller, less deeply rooted bunches succumbed as did the accompanying bluegrass, little 


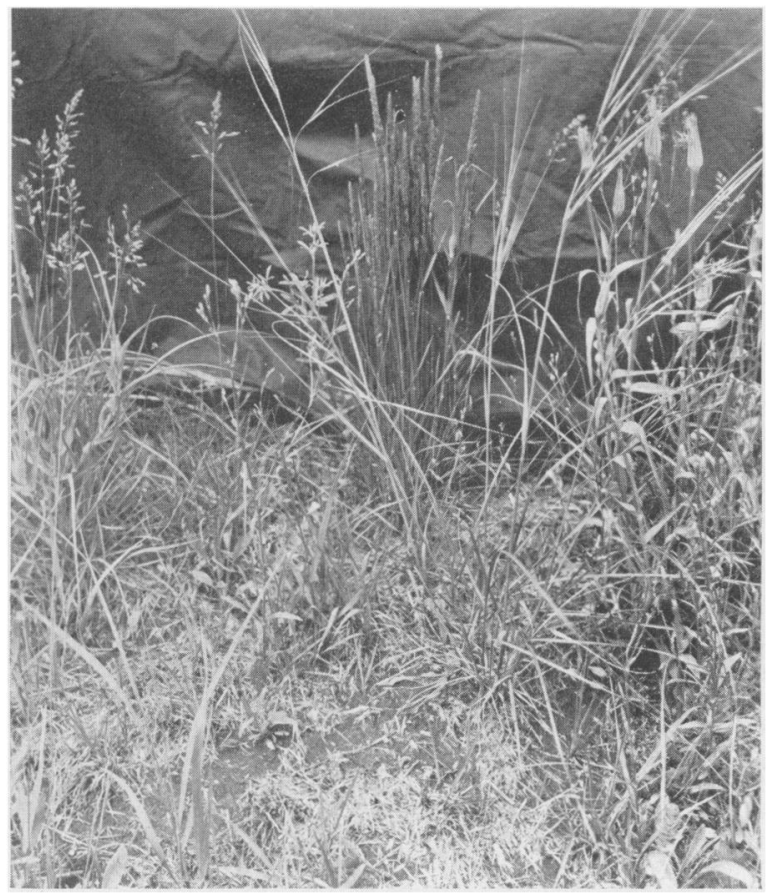

FIG. 5. An opening in the tall-grass cover resulting from drought, showing dead Andropogon scoparius and Poa pratensis, and bare soil. Stipa spartea and Kocleria cristata in background, Poa on the left, and Tragopogon pratensis and Silene antirrhina on the right. Photo at Belmont, June 7, 1935.

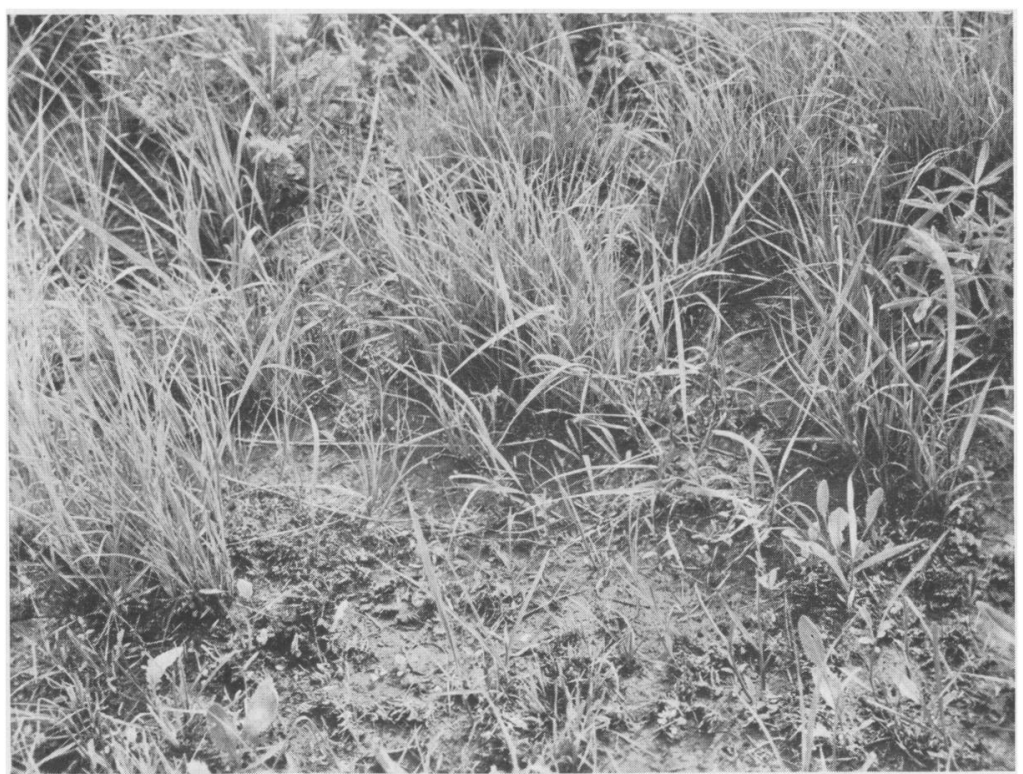

FIG. 6. Opening in the cover of Andropogon scoparius near Lincoln, resulting from drought. June 7, 1935. 


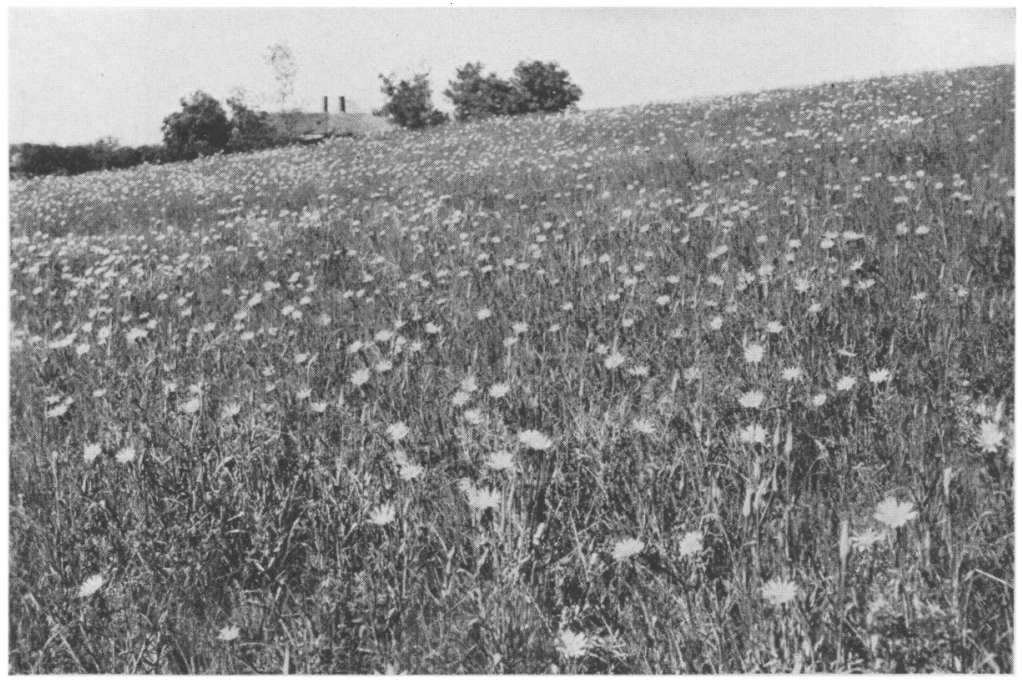

FIG. 7. Invasion of Tragopogon pratensis into upland prairie as a result of the death of much native vegetation by drought. Photo June 8, 1935.

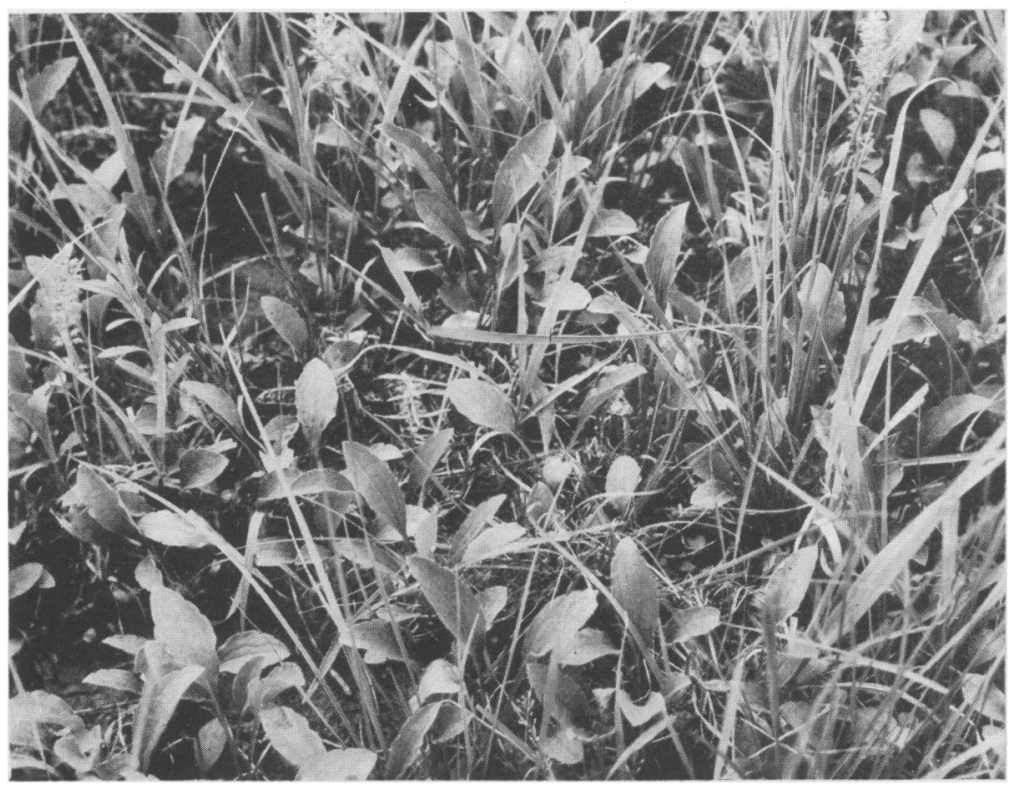

Fig. 8. Normal abundance of seedlings of Erigeron ramosus in areas left open by the death of Andropogon scoparius. Photo June 6, 1935. 
bluestem, etc. The excellent development of the widely spaced, remaining clumps produced a fine foliage cover 2.5 to 3 feet high, often with 40 stems in a single bunch, although beneath large irregular open spaces were continuous. Thus openings of moderate size graded imperceptibly into larger areas a square meter or more in extent, also destitute of living plants. Finally, the cover was so decimated that the terrain appeared almost bare with only the remnants of a former population. Where invasion by prairie forbs, such as Aster multiflorus, Solidago glaberrima, and others, liberated from competition, was pronounced or where annuals were present in abundance, the prairie had the ragged appearance of a weedy pasture. Here the percentage of remaining prairie sod was small.

Losses on many uplands were only 10 to 25 per cent and a good matrix of the native grasses remained. In others over half of the bluestems, etc., had been swept away and forbs, except deeply rooted ones, had suffered similar losses. In a few cases, where the glacial soil was thin and gravelly, the bluestems, Indian grass, bluegrass, and other less xeric species were practically exterminated and only needle grass, blue grama grass, Bouteloua gracilis, and remnants of slender grama grass, $B$. curtipendula, with certain forbs, remained.

Great destruction to species of the understory gave the grassland its distinctly open appearance. Among these species, the following were most conspicuous: Poa pratensis, Panicum scribnerianum and various other species of panic grasses of low stature, Eragrostis pectinacea, and Agrostis hyemalis. Antennaria campestris, Viola pedatifida, $V$. papilionacea, and species of Polygala were forbs which suffered great losses. The same was true of Gentiana puberula, Senecio plattensis, species of Physalis, and rosettes of Hieracium. longipilum.

Koeleria cristata was sometimes extremely abundant in burned prairies. The bunches frequently had 20 to 40 flower stalks and grew in the little-bluestem sod as thickly as 35 to 40 per square meter. Agropyron smithii, wheat grass, which formerly occurred very sparingly, made notable increases. These were most conspicuous along roadsides and in pastures where it became extremely common but it also invaded prairies. At first the stand was thin and the stalks scattered, but soon it consolidated its holdings into dense stands of 1,500 or more stems per square meter. Such potential centers of wheat grass are now common on the uplands and even more abundant on lower ground. Amount of future precipitation will determine its advance or decrease.

\section{Results from quadrats}

Numerous permanent quadrats were established, mostly on the Belmont Prairie near Lincoln, but also at Weeping Water, about thirty miles eastward, and elsewhere. These were charted during September of 1934. For clarity each quadrat usually denotes only the dominant species or two or three domi- 
nants. All of the major grasses (Weaver and Fitzpatrick, '34) were included in enough quadrats so that their recovery or lack of recovery was determined.

Selected quadrats illustrating the chief conditions and changes are shown in figures 9 to 16 . Scores of quadrats were used, however, in making deter-

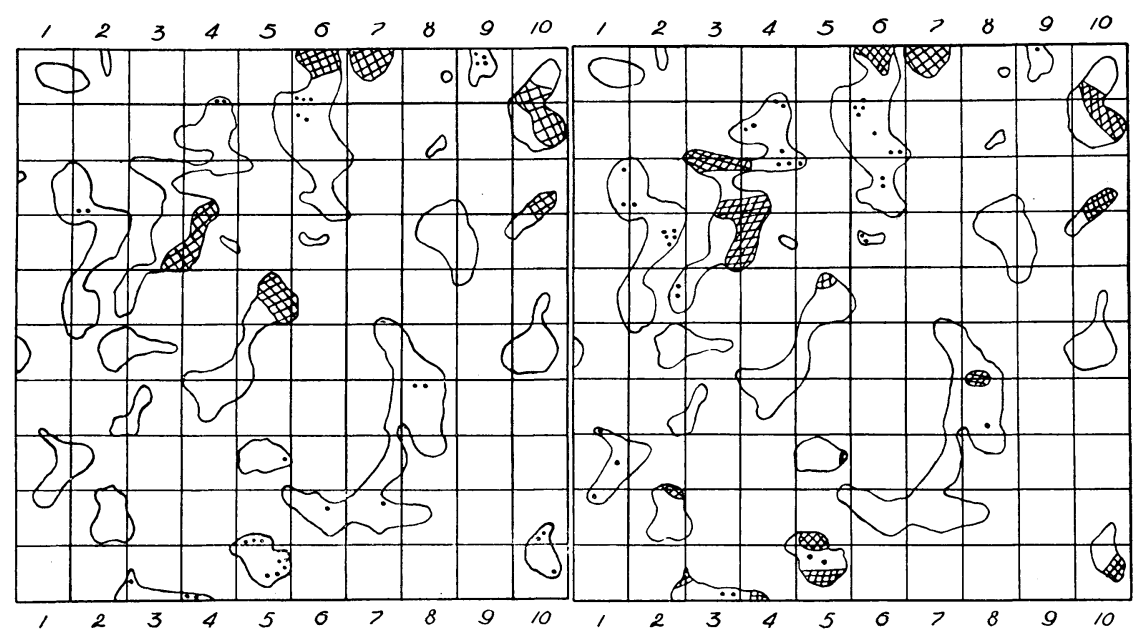

FIG. 9. Quadrat on hilltop in Belmont prairie in Andropogon scoparius consociation showing dead little bluestem (unhatched areas), living mats (cross hatched), and isolated stems (dots) in September, 1934 (left) and late in May, 1935 (right). Only 10 per cent of the grass was alive in fall but this increased to 17 per cent by the following June.

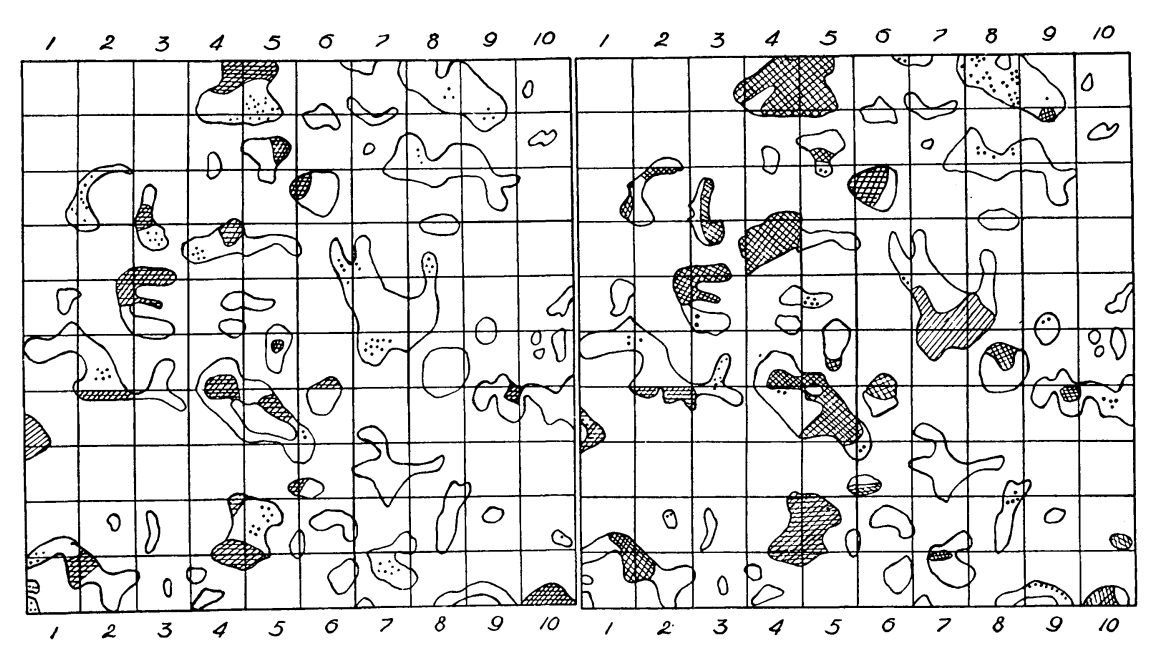

FIG. 10. Quadrat on upper north exposure in Andropogon scoparius consociation. Dead (unhatched), fully sodded (cross hatch), half populated (single hatch), and isolated stems (dots). Living plants occupied 15 per cent of the area of the bunches in fall (left) but 18 per cent in June (right). Thus recovery was somewhat less than on the hilltop. 


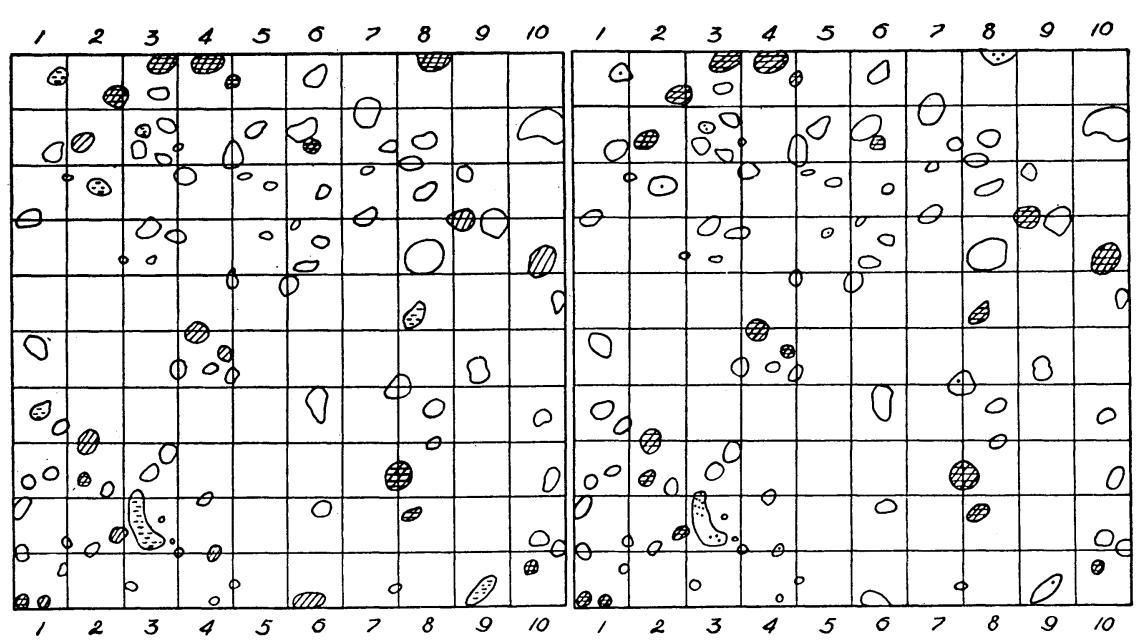

FIG. 11. Quadrat in needle-grass type on hilltop at Belmont showing dead (unhatched), unharmed (cross hatched), half dead (single hatch), and nearly dead (broken hatch) bunches of Stipa spartea. Dots indicate isolated stems. Note the great loss of the smaller (younger) bunches and the slight recovery in spring (right).

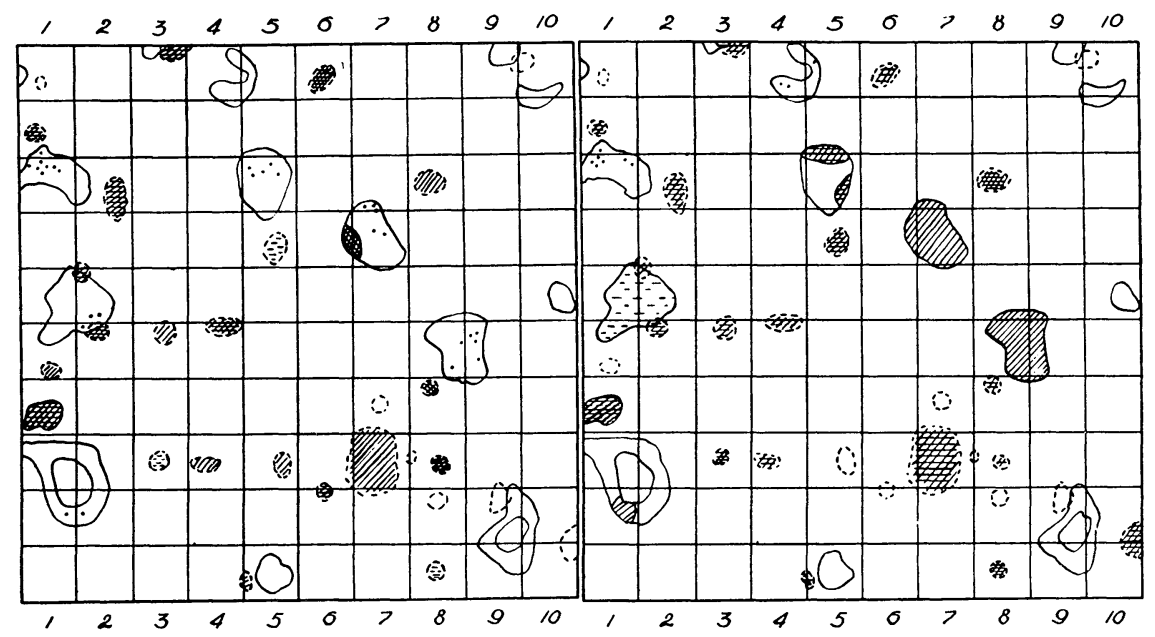

Fig. 12. Mixed bunches of Stipa (broken lines) and Andropogon scoparius (solid lines) in the fall (left) and following spring. Legend as in preceding figure. Needle grass withstood the drought much better than did little bluestem. 


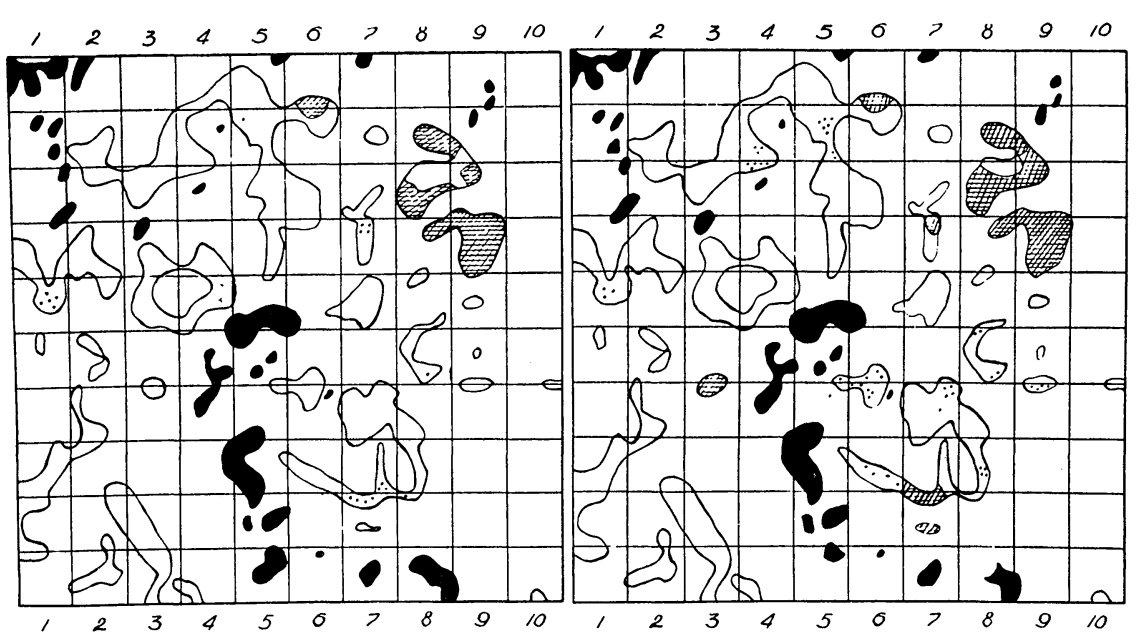

FIg. 13. Sporobolus heterolepis and living Bouteloua gracilis (black) in Belmont uplands in September (left) and in the following June (right). Prairie dropseed had suffered a loss of 85 per cent. Small winter losses of blue grama occurred.

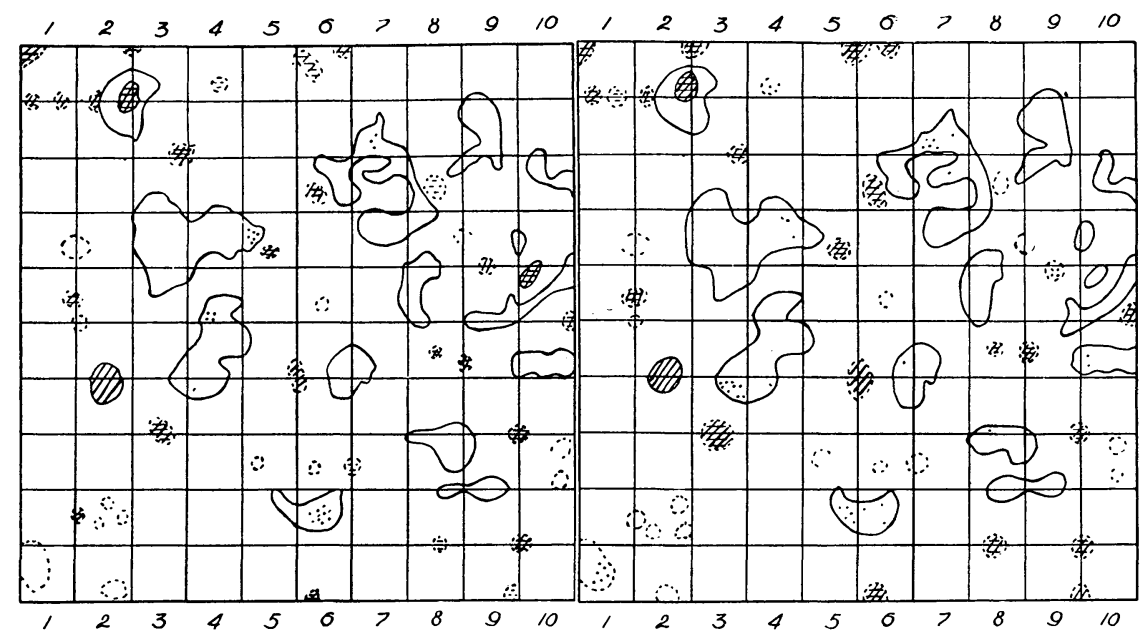

FIG. 14. Quadrat of Stipa spartca (broken lines) and Sporobolus heterolepis (solid lines) on south slope. Note that many bunches of both species are dead (unhatched) or contain only a few isolated stems (dots). Half-dead bunches are indicated by single hatch and unharmed ones by cross hatch. Losses were 35 and 93 per cent for the two species, respectively, and recovery of both was slight. 


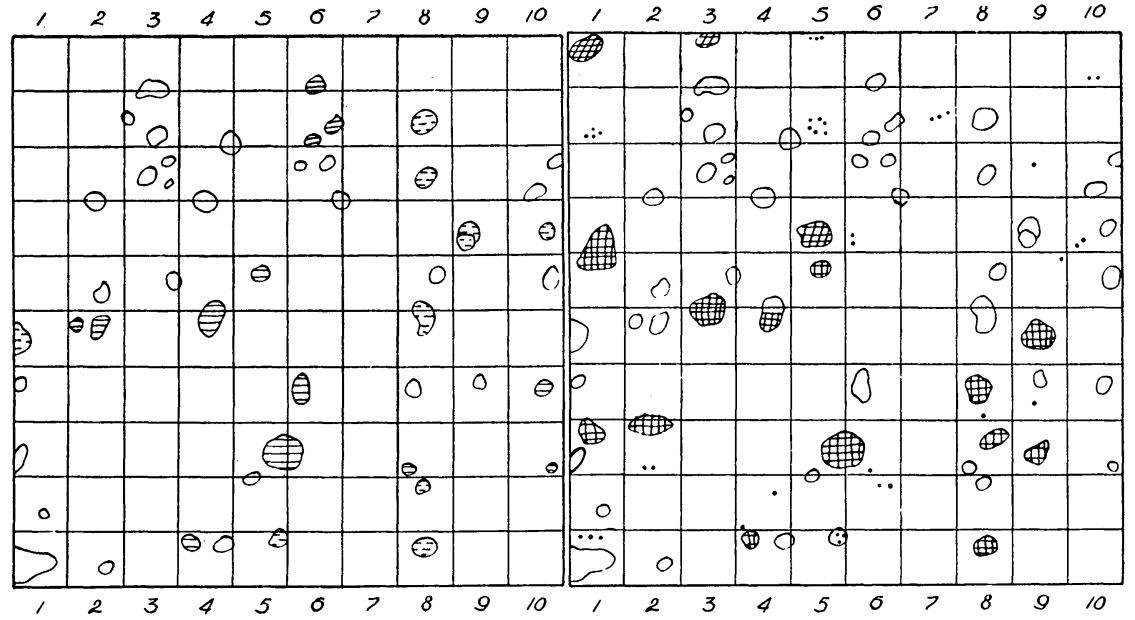

FIG. 15. Quadrat on level upland nine miles west of Lincoln, showing death of Andropogon furcatus in fall of 1934 (left) and new growth from rhizomes in May, 1935. Dead indicated by unhatched, nearly dead by broken hatch, half dead by horizontal hatch, unharmed by cross hatch and isolated stems by dots. Many new tufts were formed during the moist spring.

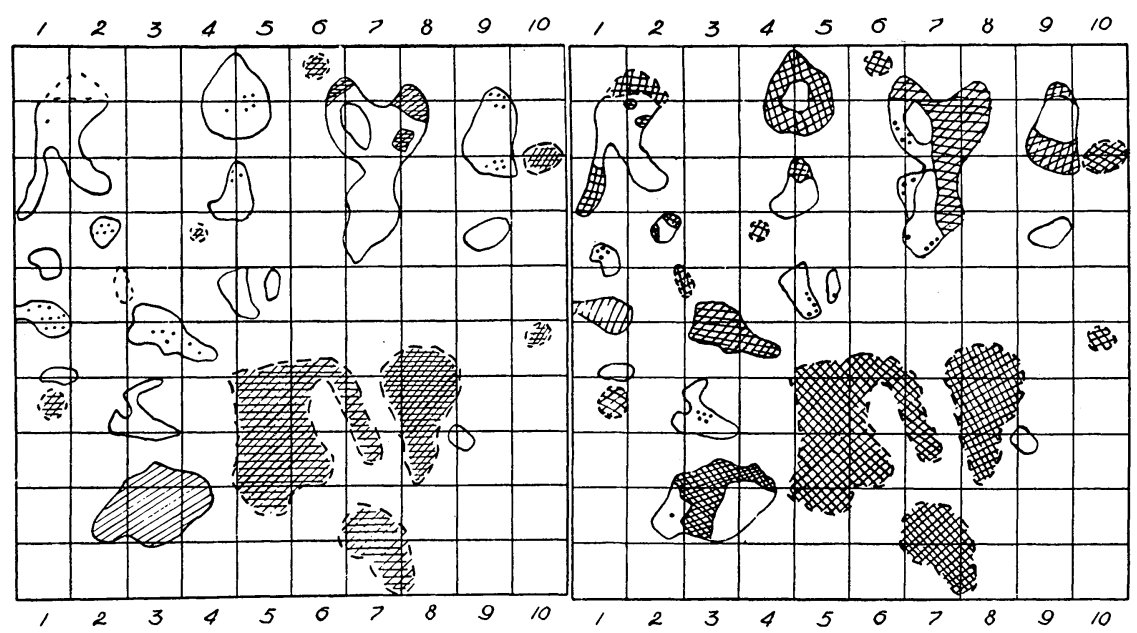

FIG. 16. Bunches of Andropogon scoparius (solid lines), Sporobolus heterolepis (long broken lines), and Stipa spartea (short broken lines) in Belmont prairie. In the fall (left), 82 per cent of Andropogon appeared dead but the following June only 48 per cent was dead (right). Sporobolus and Stipa suffered only slight injury and no loss. 
minations of losses. The moist, late spring and early summer of 1935 promoted an excellent growth of plants that were not dead, hence there was a clear line of demarcation between the living and dead portions of the bunches and sod mats despite the fact that those nearly killed by drought grew slowly.

Little bluestem suffered the greatest losses of all the grasses, not only at Belmont but also throughout the entire area. It succumbed on many xeric ridges where Stipa spartea and Bouteloua gracilis largely survived. The losses of Poa pratensis were heavy except where it was well protected by dominant grasses. Thus in burned areas and bluegrass pastures it was nearly all dried by May 15, 1934, and little revived the next season. But under the shade of other vegetation it remained green much longer and often survived the drought. Its habit of midsummer semidormancy was distinctly beneficial.

Stipa spartea lost most of its younger, less well established bunches, but otherwise resisted the drought remarkably well. It flourished during the moist early summer of 1935 and produced an enormous seed crop.

Koeleria cristata, although greatly harmed by the drought, reproduced readily by seed. During 1935, although nearly absent in the drier western prairies, it was extremely abundant, of unusual stature, and seeded prolifically in many of those eastward.

Losses of Sporobolus heterolepis were somewhat less than those of little bluestem where these species were intermixd, this grass showing distinctly more xeric tendencies.

Andropogon furcatus, although in general much less xeric than $A$. scoparius, survived, in part because of its deeper root system extending into moist subsoil, in areas where little bluestem succumbed. Its losses, however, were great almost everywhere on uplands. It showed strong powers of recovery.

Sorghastrum mutans had taken fully an 80 per cent loss at Belmont and often more elsewhere. Panicum virgatum and Elymus canadensis also suffered great decreases. Bouteloua curtipendula showed marked xeric tendencies and, although suffering greatly, held on well and usually gave good recovery.

Spartina michauxiana showed great injury during the late summer of 1934 and was unable to hold its areas even during the two preceding years. As the soil dried with a lowering of the water table in ravines and lowlands, it slowly gave way to less hydric grasses and accompanying forbs.

\section{Jamaica prairie}

This prairie consists of 65 acres of rather low, level land lying north of a stream bordered by postclimax woodland 12 miles south of Lincoln. A portion of it covers the lower slope of a south-facing hillside. It was an excellent big-bluestem prairie, this species alone furnishing 60 to 90 per cent of the cover. Little bluestem sometimes constituted as much as 25 per cent 
of the cover on the upland. Sporobolus heterolepis occurred in local alternes on lighter soil. Sorghastrum nutans, in addition to a 1 to 5 per cent mixture throughout, increased to 20 per cent or more where high waters sometimes overflowed. Slender grama grass was important on the hillside. Poa pratensis occurred as a 1 to 5 per cent sprinkling everywhere, but in many places increased to 15 per cent. In a few local alkali depressions occurred Agropyron smithii, Bulbilis dactyloides, buffalo grass, and Bouteloua gracilis.

Layering was well developed and over 70 species of forbs were listed. Aster multiflorus, Solidago glaberrima, Rosa arkansana, and Gaura parviflora were among the most important. Artemisia gnaphalodes and Hedeoma hispida were of less abundance, and Specularia perfoliata and Silene antirrhina were either infrequent or rare.

Examination during August, 1935, showed that a large alterne of wheat grass had developed. It was about 5 rods wide and extended across the prairie at the base of the slope after which it spread widely over the level ground. The wheat grass was 2.5 to 4 feet tall, the heads 6 to 8 inches long, and the stand dense (fig. 17). While the former grasses were all dead, some

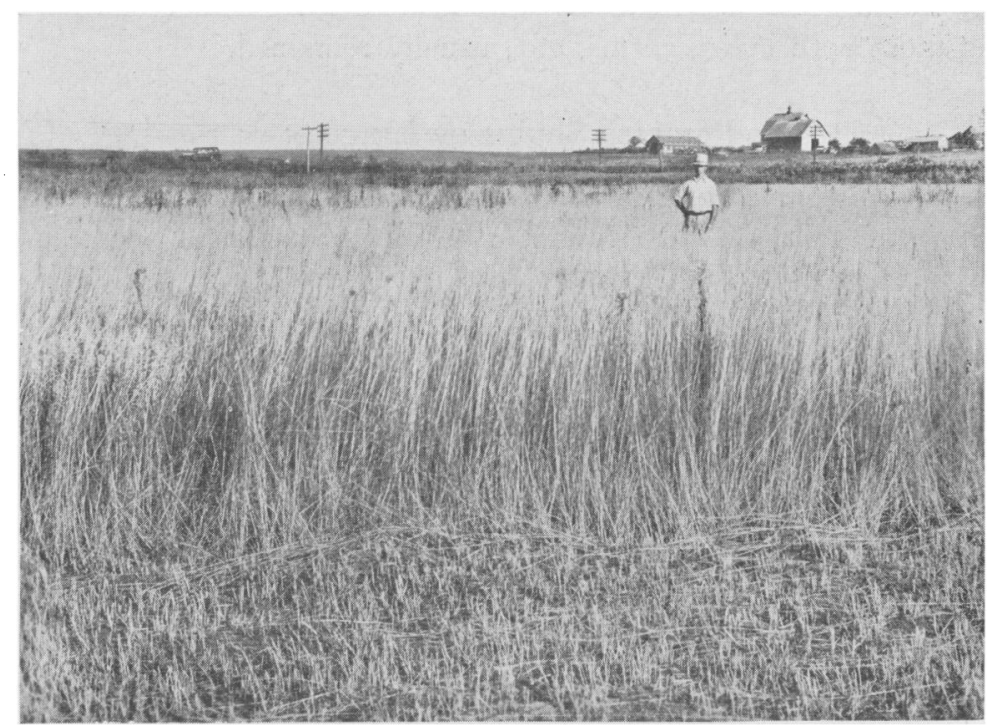

FIG. 17. Lowland near Lincoln, Nebr., formerly dominated by Andropogon furcatus which has been entirely replaced, as a result of drought, by a thick stand of Agropyron smithii.

of the forbs especially Rosa arkansana, Artemisia gnaphalodes, and Allium mutabile still persisted. Rosa and Solidago glaberrima sometimes formed an open understory and Silphium integrifolium an overstory in this dry wheatgrass alterne. Hedeoma hispida nearly always accompanied the wheat grass. 
Above the belt of wheat grass the bluestems and other grasses had been completely or almost completely replaced not only by dense growths of prairie forbs, especially Artemisia gnaphalodes and Aster multiflorus, but also by mixtures of many others. Silene antirrhina, Specularia perfoliata, Gaura parviflora, and Hedeoma hispida formed tangled growths. Accompanying or intermingled with these were dense patches of Tragopogon pratensis, Lactuca scariola, and Lepidium virginicum.

The prairie below the wheat-grass area, sheltered by the fringing woodland from the southwest winds, was in nearly normal condition. Most of the bluegrass and understory plants, however, had perished. Transition areas occurred, sometimes quite detached from the main ones but always on low ground where the wheat grass formed only half a stand and the bluestems were still abundant.

The remaining three-fourths of the prairie had suffered a great catastrophe. Wheat grass had claimed one-third, and the rest, except for a few relict patches, had been overwhelmed by weedy native or introduced forbs. Rarely only did the native grasses occur in this waste in excess of 1 to 25 per cent of the cover, and over most of the area there were none; many of the more mesic forbs were entirely absent although the more deeply rooted ones and those with bulbs, corms, etc., usually remained.

\section{Prairies South of Lincoln}

A group of four large prairies south of Lincoln and representative of that portion of the area, were found to be greatly damaged by the drought.

\section{Crete prairie}

A brief description of 160 acres of prairie near Crete, Nebraska, will represent fairly well the destruction that had occurred in the whole group.

The Crete prairie consists of level upland and lowland, gently sloping hills, and ravines. On upland the chief dominants were little bluestem with only slightly smaller amounts of big bluestem and a considerable intermixture of prairie dropseed. The bluestems alone frequently constituted 80 to 90 per cent of the plant cover. In other places the dropseed formed 10 to 35 per cent. On lowlands big bluestem alone became the sole important dominant. Other grasses common but not abundant throughout were Koeleria cristata, Stipa spartea, and Sorghastrum nutans. Extensive quadrating also showed that Poa pratensis constituted 1 to 10 per cent of the basal cover and five species of interstitial panic grasses about 1 per cent. Only an isolated plant of Agropyron smithii was found here and there. Several ravines bore excellent stands of Spartina michauxiana. Forbs were common everywhere but none occurred in unusual abundance.

The dry year of 1933 initiated some changes in the plant cover and these were pronounced by August 1, 1935. After extensive study and measure- 
ments it was ascertained that about one-half of the prairie-some lowlands, uplands with little run-off, and other favored places-had been affected by the loss of only 5 to 15 per cent of the vegetation. About one-fourth had lost 20 to 50 per cent, while over the remaining one-fourth the losses amounted to 80 to 98 per cent.

Little bluestem had taken the greatest losses among the dominants, prairie dropseed ranked second, and big bluestem had been much injured almost everywhere. Bluegrass had disappeared from one-third of the prairie, otherwise it was common. Interstitial panic grasses, formerly abundant, were not found. Indian grass and slender grama grass were represented by mere remnants. June grass, however, was about twice as abundant as normally, and needle grass had increased considerably.

Great gains had been made by wheat grass. Small alternes were common throughout the prairie, some were several square rods in extent; only the best remaining bluestem was not invaded. Aided by accumulated dust-blown soil in ravines, the former slough-grass area was now completely occupied by stands of wheat grass, so dense that no other grasses or forbs remained. Small patches of wheat grass often completely covered local areas of a few square yards with abundant flower stalks and then shaded out into surrounding areas of half dead bluestems. Here the growth was entirely vegetative, the invasion recent, and on the distant periphery of the area the stems were few. Only the tall, deepest rooted forbs remained alive in areas where wheat grass prevailed.

Aster multiflorus had spread widely until it constituted a dense, tangled, weedy growth over many acres. The plants were only 18 to 24 inches tall but very thickly distributed from the ever increasing rhizomes. Everywhere beneath them were the dead bluestems or living relicts of these and other prairie grasses. When the aster was removed the soil was almost bare.

The bare ground, and not the usual debris of accumulated stems, leaves, and bases of last year's grasses, was the prominent feature over at least half the prairie. In these bared places, resulting from extreme drought, the cracking of the soil was pronounced and rather general. The cracks were often one-fourth to three-fourths inch wide and several feet in length. Sometimes they were branched and crisscrossed in such a manner as to form large soil columns. Similar cracking of the soil was usual in the bared areas of most prairies, especially westward.

With the loss of the protecting cover of grasses, the understory vegetation practically disappeared. Such species as Viola pedatifida, Fragaria virginiana, Physalis spp., and others, although formerly common, were not found. The tall forbs, except young plants, were less affected.

Silene antirrhina, Specularia perfoliata, Erigeron ramosus, Leptilon canadense, Lepidium virginicum, and certain other weedy species were abundant. 


\section{Other prairies}

In a prairie north of Beatrice, Solidago glaberrima had become a weed quite as widely spread as was Aster multiflorus in the Crete prairie. Blossoming at a height of 30 inches, it appeared as a continuous compact society with isolated, smaller ones over nearly 20 acres. On the ground were found the dead remains of the bluestem grasses.

Wheat grass was far more advanced in a prairie west of Beatrice. It had nearly complete possession of about 20 acres and outposts were well entrenched in every square rod of the remaining half. Death toll of the former

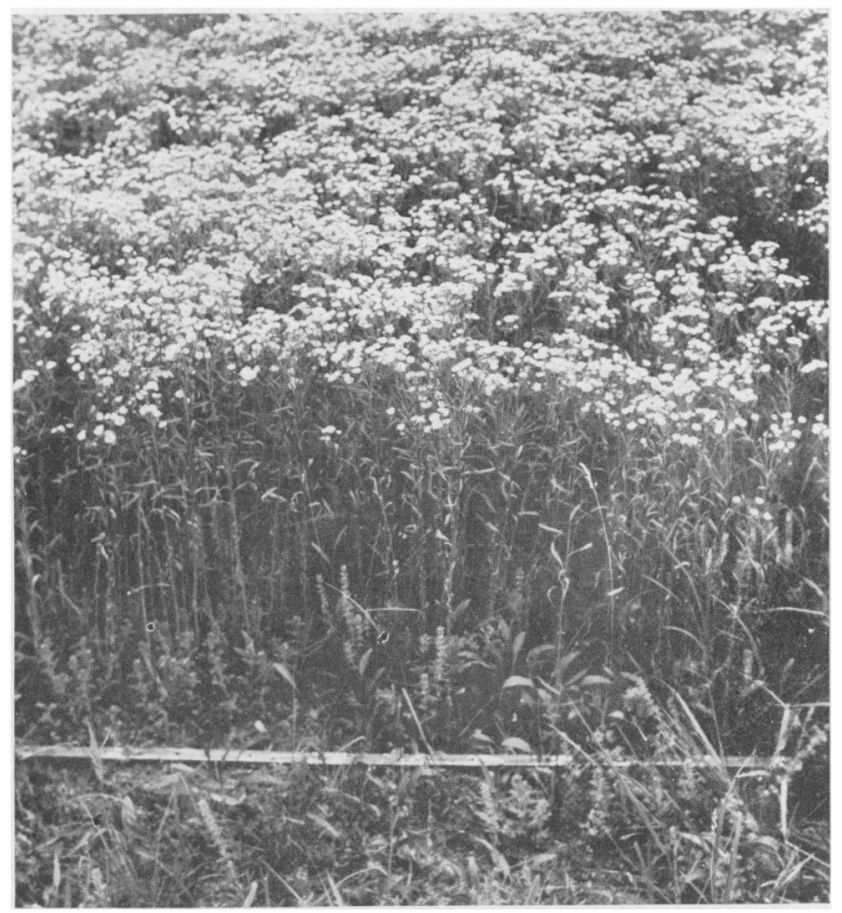

FIG. I8. Typical dense stand of Erigeron ramosus in drought-ravaged prairies of Nebraska. Photo July 6, Tecumseh, Nebr.

grasses had been heavy indeed, and many of the common forbs had been killed. Others, freed from competition, spread widely. These prairies, like those described, had not been pastured but mowed in autumn during the last 20 to 40 years.

In a prairie of 160 acres near Tecumseh, 33 miles northeast of Beatrice, the worst drought-striken areas had been invaded most extensively by Erigeron ramosus and E. annuus (fig. 18). Great societies of these weedy forbs occupied nearly a third of the prairie. Wheat grass had invaded and was rapidly increasing as was also Bromus secalinus, but to a smaller extent. General destruction was similar to that described at Crete. 


\section{Prairies Southwest of Lincoln}

A representative group of prairies about 75 miles southwest of Lincoln and including large tracts near Clay Center, Nelson, Carleton, and Hebron were also studied.

\section{Clay Center prairie}

A slightly rolling upland prairie, 20 acres in extent, near Clay Center, was described as follows after continued study in midsummer of 1931. "A typical little-bluestem prairie with a tufted sod and sometimes bunchy growth of Andropogon scoparius. In many places this species affords 90 to 95 per cent of the cover. Elsewhere $A$. furcatus contributes 5 to 20 per cent, rarely more, of the stand. Poa pratensis and Sorghastrum nutans usually add 1 to 5 per cent to the basal cover but are often absent from the quadrats. There are only traces of Stipa spartea and Sporobolus cryptandrus. Small amounts of Festuca octoflora are found and Agropyron smithii is represented occasionally by single stalks. In limited areas in the ravines, big and little bluestem share the soil almost equally. On the drier slopes Bulbilis dactyloides and Bouteloua gracilis cover considerable tracts either as an understory to little bluestem or as alternes. Here Koeleria cristata is fairly abundant.

"The number of species of forbs is not large, nor, except for Amorpha canescens, are they very important. Of first rank are Aster multiflorus, Erigeron ramosus, Artemisia gnaphalodes, Psoralea argophylla, and Solidago rigida."

This prairie was visited again on June 27, 1935. Good crops of hay had been harvested during 1932 and 1933 but the prairie was greatly damaged by the drought of 1934 . In the spring of 1935 great quantities of dust from the nearly level adjacent fields had blown in, especially from the south and west, and covered much of the area. In the ravine the new layer of soil was several inches deep; over much of the prairie it was two or more inches thick.

Not a single living plant of little bluestem could be found although the dead rhizomes were abundant under the new layer of soil. Big bluestem had persisted, however, on a part of the upland and especially in a long-abandoned prairie trail. The short grasses, where not thickly covered with soil, were thriving. Koeleria was blooming in isolated bunches.

Agropyron smithii formed a thin open stand over the areas covered to a moderate depth with dust and occurred in great alternes throughout in the shallower soil. It was densely aggregated in places. Festuca octoflora was very abundant in the bared area only shallowly covered with dust.

Deeply rooted forbs had sustained small injury; many were thriving in the absence of the competing bluestems. Artemisia gnaphalodes formed large societies as did also Solidago glaberrima. Aster multiflorus was rapidly increasing; Meriolix serrulata was abundant; and Amorpha cancescens was thriving. Half buried Liatris punctata and Solidago mollis were observed. 
Senecio plattensis, Sisyrinchium angustifolium, and other plants of small size or shallow root habit were not found. Hedeoma hispida was widely spread and abundant.

Much of the area had the appearance of an abandoned field, the remainder that of a weedy pasture. The following ruderals were abundant in the deeper new soil areas and common almost throughout: Salsola pestifer, Amaranthus retroflexus, Chenopodium album, Lepidium virginicum, Leptilon canadense, Bromus tectorum, Setaria spp., and Echinochloa crus-galli.

Thus in a 12-month period a thriving climax prairie had by drought and wind erosion been all but destroyed.

\section{Carleton prairie}

This is a nearly level upland prairie of 80 acres with a broad ravine running its entire length. The present owner homesteaded the land fifty-nine years ago. It has not been grazed but is mowed annually for hay. As was usual in the early days of settlement, a fire guard was plowed across the south end. This consisted of a strip of cultivated land about two rods wide which was annually planted to sorghum, maize, or some other tilled crop. The area was originally studied in 1931 and 1932.

Andropogon scoparius exhibited the sod-mat rather than the drier bunch type. It was the chief dominant, often forming 85 per cent of the cover, and always exceeding 60 per cent except. on the lower land where its dominance was shared about equally with $A$. furcatus. Big bluestem constituted 20 per cent of the cover as a whole, increasing to 50 per cent or more on low ground, but sometimes decreased to 5 per cent on higher lands. Everywhere it exhibited the open-sod type, intermingling freely with the other grasses. Agropyron smithii was common in the ravine where it formed 25 to 33 per cent of the vegetation. Several small areas, each a few feet square, in the driest places were clothed with Bouteloua gracilis or, less frequently, with Bulbilis dactyloides. Koeleria cristata was generally distributed but only in 3 to 5 per cent abundance. Many areas were free or nearly free from $P o a$ pratensis but in places it occurred in 5 to 15 per cent abundance. Festuca octoflora was not abundant anywhere.

The most important forbs were Erigeron ramosus, Amorpha canescens, Artemisia gnaphalodes, Callirrhoe alceoides, and Aster multiflorus. Rosa arkansana, Solidago glaberrima, and Kuhnia glutinosa were of less importance. Hedeoma hispida was found only accompanying the wheat grasses or short grasses.

During the dry years of 1933 to 1935 , great changes occurred. The little bluestems suffered a loss of 95 per cent (fig. 19). In fact, it had met death almost everywhere except in the lowest places where it was protected by big bluestem. Losses of big bluestem were 10 to 15 per cent. Bluegrass remained only in the most moist places, but here it often occurred thickly. 
No Indian grass was found. Certain other grasses, however, had made great gains, especially western wheat grass. Half of the entire prairie was now dominated by this species and one-fourth or more of the remainder was shared to the extent of 50 per cent. Less than one-fourth of the prairie was still held by the bluestems.

Wheat-grass alternes.-Over extensive areas wheat grass was three feet tall. In much of the territory where it was best developed all of the more mesic grasses (bluestems, bluegrass, and others) had been entirely swept away although their dead remains were still eloquent of former possession. Often the basal cover of wheat grass did not exceed 1 to 3 per cent. The

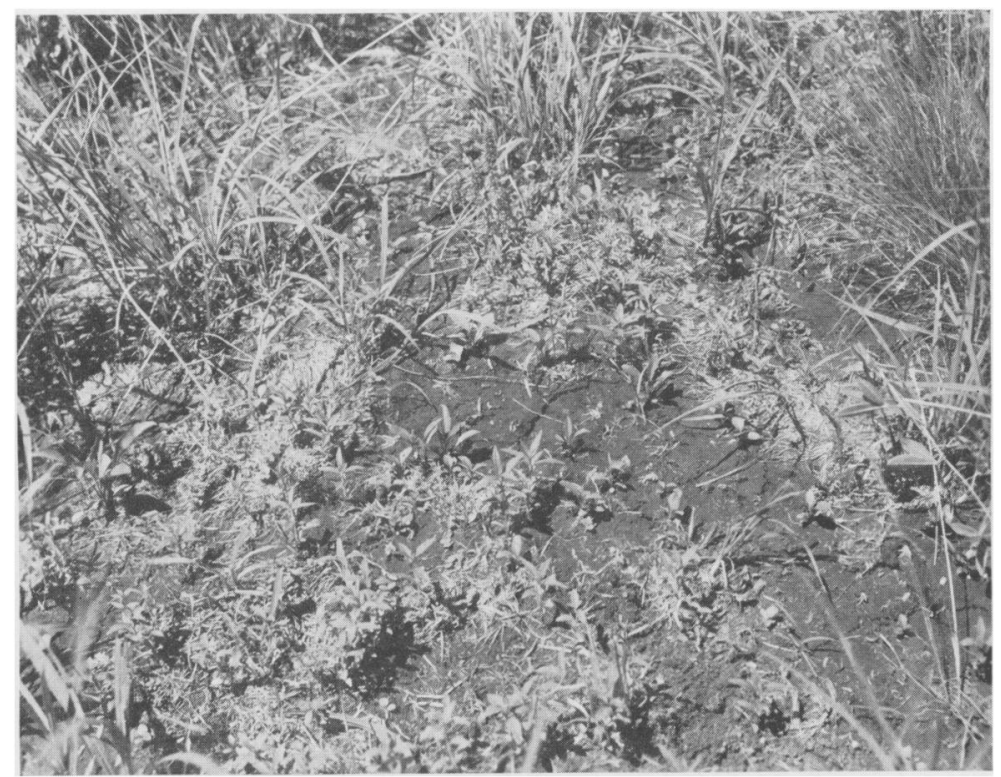

FIG. 19. Typical bare area in Carleton prairie due to death of little and big bluestem. Photo June 28, 1935.

lack of consolidation of the tufts into a dense sod showed that it had not been on the ground many years. Not infrequently extensive growths of blue grama grass or patches of buffalo grass formed an understory to the wheat grass. The seed crop of all three species was remarkably heavy. In other areas the short grasses formed alternes free of wheat grass as is typical of mixed prairie. This change in plant population had occurred within two or three years as a result of drought. The dead roots and rhizomes of the former bluestem dominants were everywhere, and in some places a few scattered living stems of big bluestem outlined or at least indicated the position of the former clumps. Drought had been so destructive that most of the wheat-grass area was no longer mixed but almost pure wheat grass. 
Remaining bluestems.-In areas adjacent to wheat grass but on lower ground, the bluestems had not been routed and, indeed, little or no wheat grass was found. Locally, where drought had been least severe, big bluestem was frequently mixed on equal terms with little bluestem. Practically no bluegrass remained, but Kocleria cristata was common. Where great patches of ripened Festuca octoflora were found, much damage had been done. Here little bluestem was mostly dead and greatly injured big bluestem with halfdead bunches of Bouteloua curtipendula were found. Bunches of 20 to 50 stems of the fescue 18 to 20 inches tall were growing in the dead bunches of the bluestems. Extent of drought injury was often directly indicated by the density of stand of the fescue. Losses varied from 5 to 95 per cent on this nearly level, low ground. Frequently the little bluestem was entirely killed and the big bluestem, which made up 5 to 10 per cent of the cover, had not increased (fig. 20). Conversely, where big bluestem had been the most

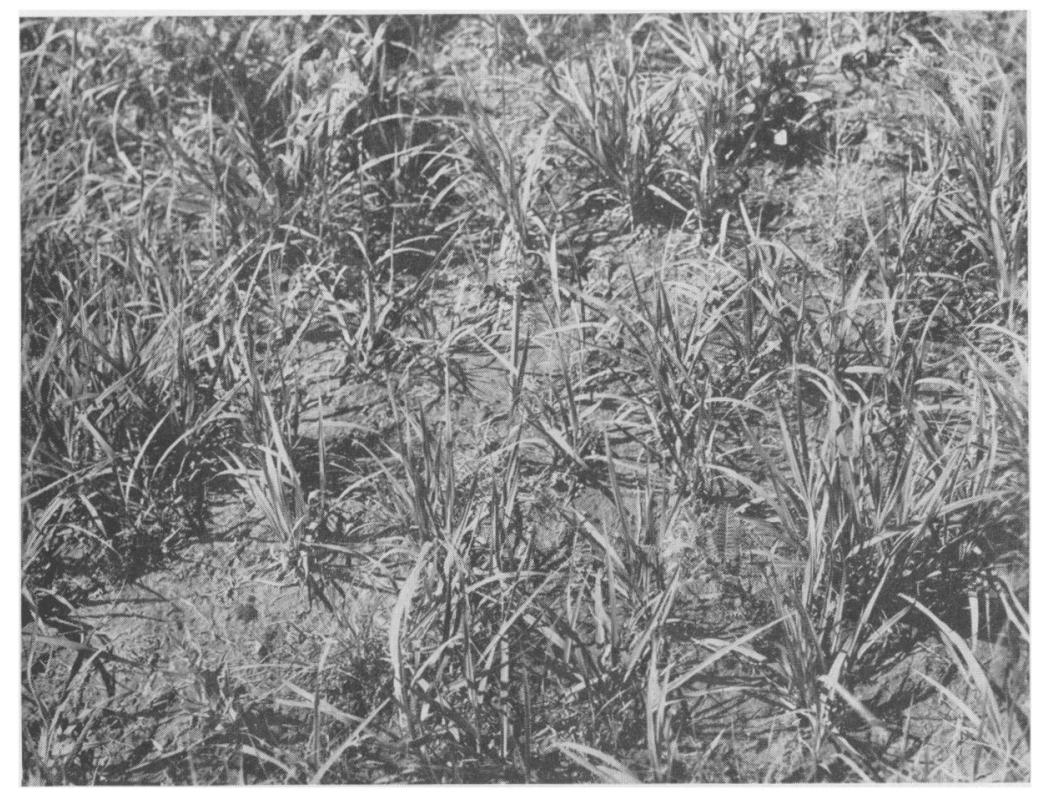

FIG. 20. An open cover of Andropogon furcatus resulting from the death by drought of the more shallowly rooted $A$. scoparius at Carleton, Nebraska.

important grass, the drought losses did not exceed 10 per cent. But commonly areas of 2 to 4 square feet, but of irregular shape, were bare of all vegetation. These may be reclaimed by big bluestem, but where both the former dominants had been killed, wheat grass had regularly invaded.

Mixed bluestems and wheat grass.-Over other large areas wheat grass had only partly claimed the prairie. Here it was mixed with 5 to 50 per cent or more of big bluestem, with the fragments of little bluestem that re- 
mained, and with other prairie grasses and forbs. The alternes of grama grass were more numerous and much larger than before. Except for the short grasses, the lower layer of grasses and forbs was scarcely represented. Several species of only moderately deeply rooted forbs had nearly or entirely disappeared, while others with deeper root penetration had greatly increased.

Aster multiflorus had increased enormously, except in the least disturbed part of the prairie. Over considerable areas where drought had struck, but wheat grass had not invaded, it was practically the only species. The plants no longer formed bunches but a more or less uniform stand with rhizomes interwoven and hundreds of stems per square meter. It had claimed other areas in competition with the wheat grass.

Kuhnia glutinosa was prominent throughout except in the least disturbed parts. Its seedlings were abundant in many bare places as were also those of Erigeron ramosus and Aster multiflorus. Rosa arkansana was locally very prominent. Amorpha canescens remained green and was thriving although almost overwhelmed by the tall wheat grass. Silene antirrhina was common everywhere in bare areas but less so in the wheat grass. Hedeoma hispida, usually confined to short-grass alternes, was common to abundant everywhere. The lack of an abundance of Russian thistle, rough pigweed, etc., indicated an absence of accumulated drifts of dust.

The once uniform cover of vegetation presented an extremely disturbed, varied, and dynamic appearance. In the sea of drying wheat grass were revealed the islands of native bluestems, appearing at a distance little disturbed. Thinner stands of wheat grass indicated less drastic effects of drought, particularly on the big bluestem. The brown alternes of Festuca were strewn over the dead bodies of the former dominants while tangled patches of Aster multiflorus defaced similar scars of drought, but the land was made worthless. Which way the balance will swing in future years is dependent upon the amount of precipitation.

\section{Nelson and Hebron prairies}

A fine little bluestem prairie with one-third of the area shared equally with big bluestem lies near Nelson, Nebraska. It was in a thriving condition and free from invaders when studied in 1931.

By midsummer of 1935 half of the area had become covered with a layer of soil to a depth of about 0.5 inch. The native grasses had vanished. In their place Bromus secalinus (or a closely related species) and Festuca octoflora held complete possession except for a few deeply rooted native forbs, chiefly Amorpha canescens. Isolated alternes of wheat grass marked places where the wind-blown soil was about an inch deep.

Over the remaining half, Festuca octoflora and Andropogon furcatus were the chief grasses. A. scoparius was represented only by the merest remnants. Bare soil was everywhere, being clearly visible even at a distance. Although 
big bluestem was sprinkled throughout, it was never consolidated except in the ravines where the stand was about one-half normal. Seedlings of Koeleria and Poa were common but there were no old plants. Dead rhizomes and bare soil declared the ravages of drought. Few or no interstitial species were found and few weeds had invaded. But for Festuca, the foliage cover, except on steep north banks, nowhere exceeded 30 per cent and frequently fell to 5 to 10 per cent. Amorpha and about eight other deeply rooted species composed the sparse societies.

At Hebron losses varied from 95 per cent on upper and middle slopes of south facing hills to 10 per cent near their foot. Elsewhere whole hillsides were covered with the dried, brown bunches of Festuca octoflora, or patches of Erigeron ramosus, alternes of wheat grass, and various weeds. The native perennial grass had been completely killed over many square rods and only relict patches remained in ravines and other favored places.

\section{Prairies of Southwestern Iowa}

Study of a group of four prairies in southwestern Iowa, and two in southeastern Nebraska, none of which had been seriously if at all damaged, was made in 1935.

\section{Glenwood and Corning prairies}

Examination of prairies on the deep moist soils of the loess hills at Glenwood revealed that they had not been harmed by the drought. They were even better developed as regards height and density of foliage cover than at the previous examinations in 1931 and 1932.

Some drought effects were found in western Iowa on the glacial soils. An example is illustrated by the prairie at Corning, Iowa. This prairie covered hilltops, various slopes and valleys, as well as level uplands, and is typical of the rolling topography. The upland cover is of the well developed, littlebluestem sod-mat type except on the steepest slopes where the grass sometimes resorts to the bunch habit. Big bluestem occurs everywhere, shares equally the lower mesic slopes with little bluestem and forms fully 85 per cent of the cover on lower ground. Some alternes of Sporobolus heterolepis occur on the hill crests, while those of Spartina michauxiana with fringing Elymus canadensis and Panicum occupy the larger ravines.

The dry years had affected lowland vegetation by greatly decreasing the slough grass. In fact, with the lowering of the water table it had all but disappeared from the ravines and was replaced by Agrostis palustris and Poa pratensis. The stronghold of big bluestem in the lowlands had been somewhat weakened, the species being much more intermixed with little bluestem and other grasses.

The little-bluestem sod was scarcely disturbed on east and northerly slopes, but the loss on the uplands varied from 20 to 50 per cent. Other grasses such 
as Sorghastrum nutans, Sporobolus heterolepis, Poa pratensis, Andropogon furcatus, and Bouteloua curtipendula were also considerably harmed. Many interstitials still remained, notably Antennaria campestris, rosettes of Hieracium longipilum, Polygala alba, young Zizia aurea, Pedicularis canadensis, and others. Koeleria was unusually abundant in these drought areas and Aster multiflorus had greatly increased along the driest ridge.

\section{Anita and Oakland prairies}

At Anita, Iowa, no traces of drought were in evidence. The tall, dense cover of vegetation with a wonderfully developed understory and an abundance of forbs overtopping the grasses was in striking contrast to the drought ravaged grasslands to the westward. Little bluestem was 18 inches tall on the driest slopes. Such species as Fragaria virginiana, Antennaria campestris, Physalis lanceolata, and Zizia aurea, as well as others which had not been able to endure the drought westward even on lowland, were here flourishing on the hilltops.

Similar conditions were found in a fine 40-acre prairie at Oakland, Iowa. The rank growth of grasses and forbs assured an unusually heavy yield of hay. At both stations sufficient rainfall had occurred to promote the usual excellent growth.

\section{Prairies at Auburn and Nebraska City}

At Auburn, in southeastern Nebraska, no harm had befallen the prairie probably because of timely local showers, although 20 miles northward at Nebraska City, considerable change had occurred. This prairie, fully described by Thornber ('01), has been intimately known by the writer since 1921 (Clements and Weaver, '24).

It is an area of 160 acres, much diversified in type. In ravines where Elymus canadensis formerly dominated, this species was much less abundant. Spartina michauxiana, which formerly covered a large tract of lowland, was in poor condition and much of its territory had been successfully invaded by Panicum virgatum and other less hydric species. This resulted from a general lowering of the water table.

In the extensive alternes of Stipa spartea the dead rhizomes of both of the bluestems, Sorghastrum nutans, and Poa pratensis were found everywhere. In fact little bluestem and bluegrass had practically disappeared as components of the Stipa vegetation. Many of the more shallowly rooted, younger bunches of Stipa had also died, but the excellent growth and widely spreading foliage of the current year obscured these losses. When the foliage was brushed aside, however, bare areas 1 to 3 or more square feet in extent were found in nearly every square meter. These bare areas, very irregular in outline, were practically continuous. Stipa had made such an excellent growth 
that it appeared to dominate in much of the little-bluestem territory where its abundance in the basal cover was actually only 15 per cent. Outside the Stipa alternes losses of the bluestems and other grasses were far less. On midslopes they rarely exceeded 5 to 10 per cent but increased to 50 per cent locally. Careful measurements revealed that of this loss nearly four-fifths was that of little bluestem and bluegrass. The usual, widely spread weeds viz., Lepidium, Leptilon, and Silene occurred, but not abundantly. Erigeron was unusually abundant but wheat grass was represented very locally in a few greatly disturbed places.

\section{Prairies in North Central Kansas}

A study of three tall-grass prairies was made just east of Mankato, Kansas, at Montrose, Belleville, and Haddam.

\section{Montrose prairie}

This prairie of 60 acres of moderately rolling land with some nearly level areas and shallow ravines, was examined in July, 1931, and again in June, 1932. "A large part is clothed with the Andropogon scoparius type with little bluestem furnishing 65 to 80 per cent or more of the plant cover. $A$. furcatus is present everywhere varying in importance from 5 to 20 per cent except on banks of ravines and in shallow draws where it usually takes complete possession. Hence there are considerable areas where big and little bluestem form a nearly equal mixture. Sorghastrum nutans ranks third in importance. It forms 3 to 5 per cent of the cover except on the long north slope which has been repeatedly burned. Here it replaces little bluestem in part and increases to 10 to 15 per cent. Bluegrass is often absent but usually ranges from 1 to 5 per cent in abundance. A. furcatus decreases to less than 10 per cent on south slopes, Koeleria cristata increases in abundance to 3 to 5 per cent, and Bouteloua curtipendula has holdings of 10 to 15 per cent between the bluestem bunches. Even spears of Agropyron smithii are seen and an occasional clump of Bouteloua gracilis and Bulbilis dactyloides. Forbs are abundant as regards species but the societies are not well developed."

Even casual examination late in June of 1935 showed that much damage had been done, and detailed examination revealed the nature of the destruction. Little bluestem had been injured most, in fact only mere remnants (about 1\%) were left. Often big bluestem and slender grama remained where little bluestem had all died. Great mats of dead bunches and small clumps of grasses occurred everywhere. The basal cover was very open even on low ground, and the foliage cover did not exceed 50 per cent. In many places fully 75 per cent of the former vegetation had died, and of ten on flat hilltops big bluestem alone was left. The dead tases of the bluestems and other grasses were conspicuous everywhere. In several areas where 
the scattered ruderal invaders were removed, only 1 per cent of the native grasses was alive. The rest was bare ground. Over the area as a whole the foliage cover (including invaders) was typically 25 to 30 per cent and the former basal cover of about 15 per cent had been reduced to 3 to 5 per cent. Even in the most favored situations losses of the bluestems were 10 to 20 per cent. Losses of the big bluestem were very severe; Indian grass suffered even more. A few good areas of big bluestem were found but these were local in or near the ravines. Bouteloua curtipendula had lost much ground. There was no Stipa spartea, and Kocleria cristata was represented only by seedlings. Bluegrass had been swept away, and the smaller interstitial panic grasses and forbs (except Oxalis violacea) were rare. Pro-

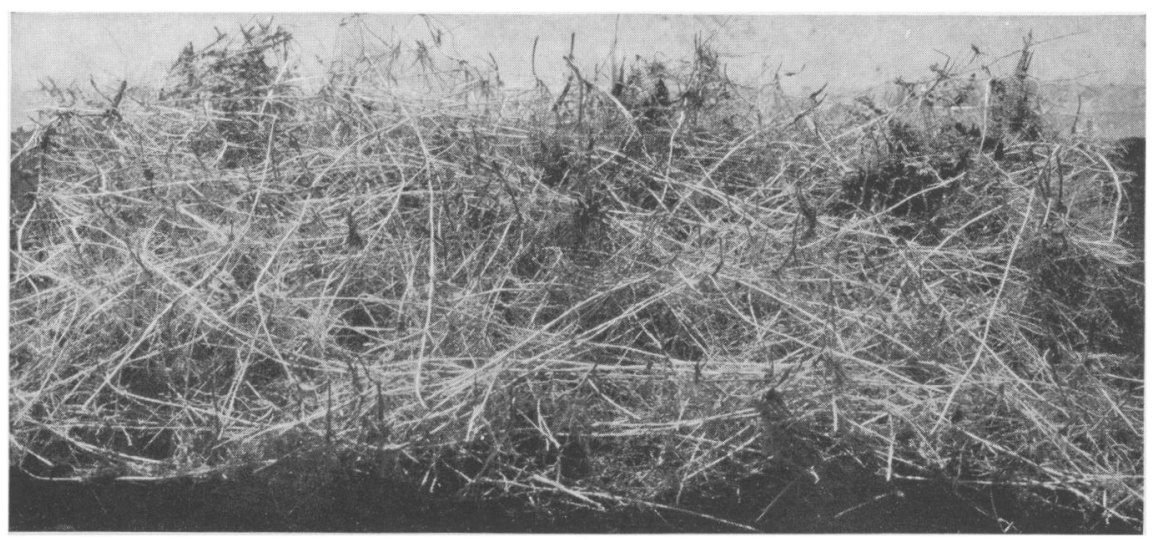

FIG. 21. Invasion of Agropyron into big-bluestem sod. The soil was washed away from this one-half square meter of sod revealing the dead underground parts of the former dominant (black) and the shining white rhizomes of wheat grass.

tection by the taller plants had failed and they had succumbed. Everywhere the soil was open to invaders.

Buffalo grass and blue grama grass had endured the drought well. The first especially was invading areas occupied by the bluestems and other less xeric grasses. They were thriving in the barest areas, growing in the old bunches of grasses as well as between them. Wheat grass had appeared in many places. Wherever soil had drifted in it occurred abundantly but it was also thriving in the barest areas (fig. 21). It was frequently intermixed with the short grasses. Many native forbs had almost or entirely disappeared and none had yet spread to such an extent as to constitute bad weeds. While the area was not weedy, there was an abundant potential weed population.

Salsola pestifer was common, Helianthus annuus was scattered throughout, and Chenopodium album, Lepidium virginicum, Amaranthus retroflexus, Hordeum pusillum, and Solanum rostratum occurred frequently. 


\section{Belleville prairie}

This prairie, studied in midsummer of 1931, consists of about 30 acres with long east, west, and north slopes and a well developed broad ravine along the entire north side. The lowest part of the ravine bore a pure stand of Spartina michauxiana. About 5 acres supported an excellent stand of Andropogon furcatus with a little Sorghastrum nutans, and with intermixed $P a-$ nicum virgatum and Elymus canadensis on the wetter margins. There was a good understory of Poa pratensis. A very localized zone of Agropyron smithii occurred in one portion. The higher land on all slopes was dominated by Andropogon scoparius with about 15 per cent of Koeleria cristata and a good admixture of $A$. furcatus. The steep portions of the hills showed locally almost pure alternes of Bulbilis dactyloides and Bouteloua gracilis with bunches of Sporobolus asper, Opuntia spp., Plantago purshii, and Hedeoma hispida. About these, as well as throughout the bluestem sod, Bouteloua curtipendula was well distributed.

By 1935 the small wheat-grass alterne had developed into a large one 2 to 3 rods wide and 10 rods long. Dust had covered most of the lowland 0.5 to 1 inch deep and nine-tenths of the bluestem area was occupied by a nearly pure stand of wheat grass. The slough-grass area was much less extensive and had been replaced in part by Panicum virgatum and Elymus canadensis. Some bluegrass still persisted. A dust cover of even an inch was very detrimental to the bluestem. Where dust blew from the hillside and did not lodge immediately next to the bank, the uncovered area was still occupied by big bluestem. Otherwise the banks too were sodded over with wheat grass. Nearly all low-growing forbs were absent.

Where much dust was deposited on the uplands, an open stand of wheat grass prevailed with only relicts of former grasses. Here the basal cover usually did not exceed 2 per cent. Little bluestem was all dead on the westfacing slope, and only traces remained on the east one. Big bluestem was represented by the merest relicts. In fact, fully 95 per cent of the original tall grass had died; where most sheltered, scarcely 25 per cent remained. There was no Sorghastrum, only a little Bouteloua curtipendula, and small amounts of Koeleria. Many plants of Opuntia humifusa had died and decayed.

Although both blue grama grass and buffalo grass had suffered considerable losses, as shown by marked thinning of the stand, both were rapidly recovering. They still held their former areas and buffalo grass especially was spreading rapidly. New centers were being established over the slopes. Aster multiflorus, only 8 to 12 inches tall, formed great patches and was rapidly reclaiming the bared land. Spermolepis divaricata had spread widely.

Great bare areas were everywhere and erosion by wind and water was imminent. Plants of the understory had disappeared. Weeds populated the soil thinly in places, elsewhere they grew thickly. The chief invaders were 
Bromus secalinus and Festuca octoflora, both in extensive alternes (figs. 22 and 23). Other weeds of much importance were Silene antirrhina, Lepidium virginicum, Hordeum pusillum, B. tectorum, Plantago purshii, and Chenopodium album.

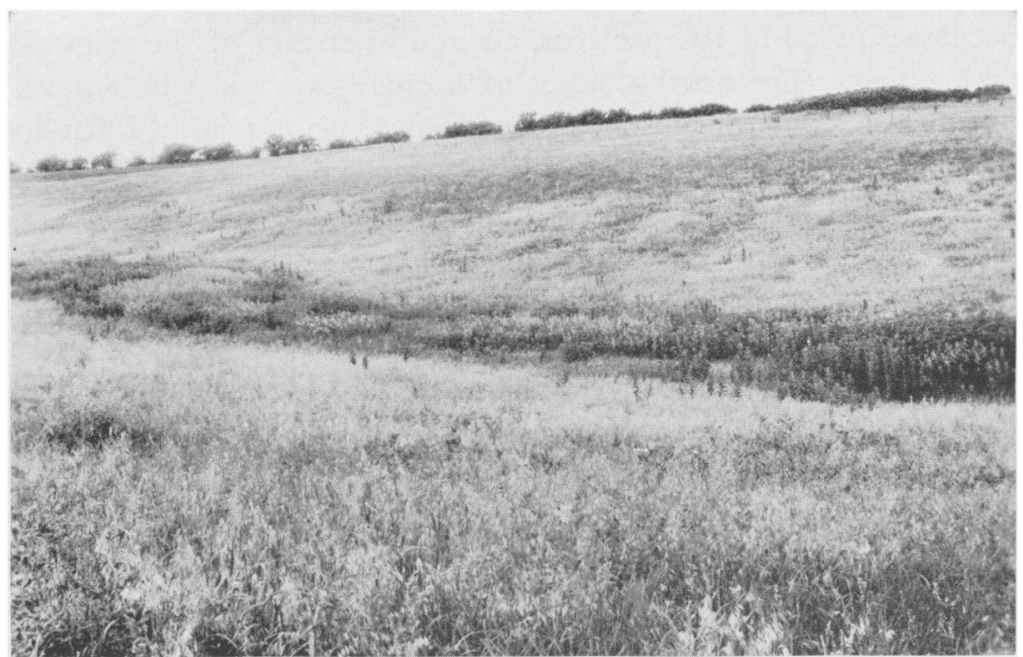

Fig. 22. Alternes of Bromus secalinus (light colored) in prairie badly depleted by drought near Haddam, Kansas. July 1, 1935.

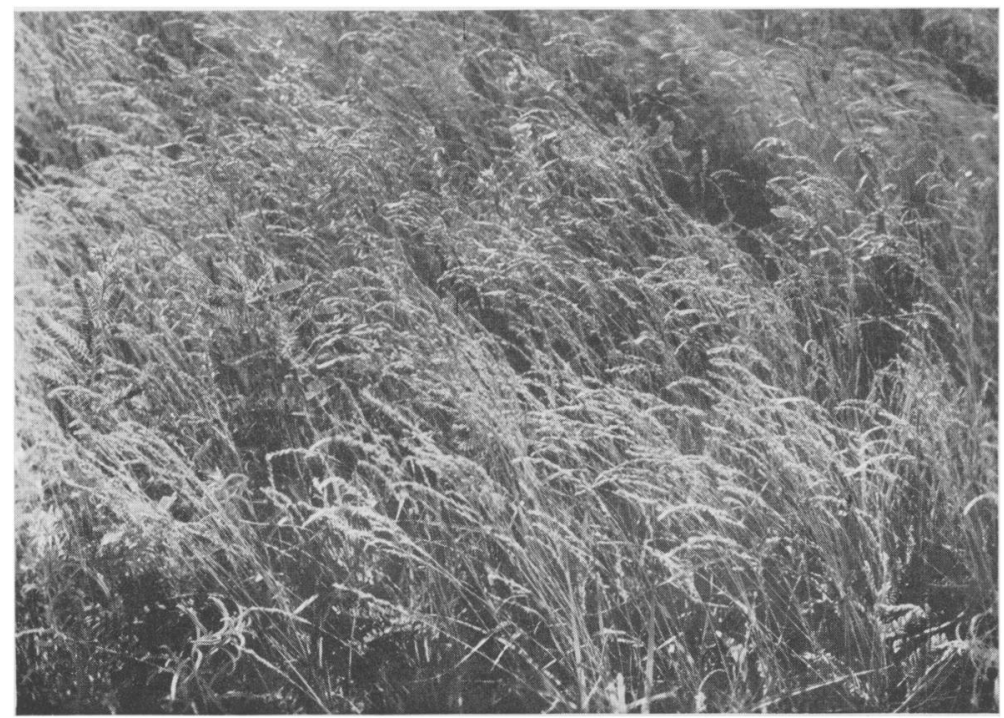

FIG. 23. Dense stand of Festuca octoflora in prairie near Belleville, Kansas, in ground formerly occupied by little bluestem. 


\section{Haddam prairie}

Only about 8 acres of a 40-acre prairie near Haddam, Kansas, remained largely intact. It had the double advantage of the protection of a dense hedge of untrimmed Maclura pomifera and a north slope exposure. Even here there was 20 to 50 per cent loss. Over the remainder, the bluestems had met losses of 60 to 100 per cent, about 15 per cent of the original grass cover remaining. The usual alternes of brome grass and wheat grass were extensive. Aster multiflorus and Spermolepis divaricata formed dense weedy patches, and practically all of the ruderals of other prairies were also found here.

\section{Loss of Interstitials}

With the wilting of the layer of grasses on uplands and their death over great areas, plants of the ground layer were not afforded the usual protection from insolation at this most critical time of great drought. Consequently most of the understory species suffered great losses and in the drier, western prairies practically all succumbed. This change was impressive.

Antennaria campestris, one of the seven most important prairie forbs, was all but swept away from the more western prairies and suffered enormous losses elsewhere. The fibrous roots apparently do not penetrate very deeply. The plants made some gains in 1935 , but by midsummer new shoots, like those of shallow-rooted seedlings, began to wilt as water in the surface layers of soil again became exhausted.

Poa pratensis was almost completely killed except in a very few usually wet spots in the westernmost prairies. Eastward it died on hilltops and exposed slopes and even on lower ones where the old debris had been removed by fire. In many nearly level prairies it remained only in the bottom of ravines.

Panicum scribnerianum, $P$. wilcoxianum, and other low-growing panic grasses were affected to an extent similar to that of bluegrass. During 1935 they were rarely found. Other interstitial grasses somewhat similarly affected were Agrostis hyemalis and Eragrostis pectinacea.

In general the basal cover was reduced somewhat in proportion to the death of the tall grasses. Anemone cylindrica and rosettes of Hieracium longipilum practically disappeared. Fragaria virginiana, Viola pedatifida, $V$. papilionacea, Antennaria plantaginifolia, Senecio plattensis, species of Polygala, Sisyrinchium, and Physalis are further examples of plants that suffered especially from the drought. Galium tinctorium and Anemone canadensis as well as many others were greatly depleted or failed to grow on low ground.

Among taller plants, Equisetum laevigatum and Toxicodendron rydbergii were greatly injured or killed. 


\section{InCRease in Native Grasses}

Agropyron smithii made the greatest increase of any native grass. Formerly it occurred only sparingly in the eastern prairies and was confined mostly to the thinner soils and especially to roadsicles, alkali spots, or greatly disturbed places. It is now widely established along roadsides, especially where disturbance such as dust accumulation has occurred. Entrenched at least in small areas in practically all of the disturbed prairies and taking possession of extensive areas in others, especially westward, it has caused profound change. It thrives in places where the bluestems have died, promptly reclaims areas overwhelmed by dust, and from these vantage points has rapidly extended its territory during the years of drought. Only deeply rooted forbs remain in the dense sod of this tall grass. Its vigorous growth in early spring and its migration by long, slender rhizomes are distinct assets.

Bulbilis dactyloides, profiting by the death of its tall competitors, is increasing its holdings, often very vigorously, in grasslands bordering the mixed prairie. Bouteloua gracilis is behaving similarly although its invasion is much slower. It is also locally common on the steepest upper slopes in the center of the area. It was almost unharmed in the same square meters where all of the little bluestem died.

Festuca octoflora has become abundant in the bare areas of the eastern Nebraska prairies. Westward its abundance has increased until it is locally in complete possession of hilltops and slopes where the dominant grasses have died. Bunches of 20 to 30 stems of this annual growing out of the dead crown of little bluestem were found regularly. In a single square meter, 200 bunches were not uncommon. The abundant and very light seed ripens in July and is broadcast by the wind.

\section{InVASION BY NATIVE FORBS}

Aster multiflorus has become a bad weed in many of the prairies throughout the area, but not in all, being almost absent in some that were greatly disturbed. It ranged from great local abundance to complete temporary control over one-fifth to one-half of certain large prairies. The thick stand of somewhat woody, tangled stems, 18 to 26 inches tall, formed almost thicket-like growths.

Erigeron ramosus has become a bad weed in about half of the droughtdamaged prairies. This annual seeded so thickly that frequently 20 to 30 plants per square decimeter clothed the bare soil where the grasses had died. Height varied from 12 to 30 inches. Extensive societies, distinguishable at long distances, were common.

The catchfly, Silene antirrhina, usually not at all abundant in prairie, was one of the five most important, weedy native forbs. It was found in all but a few of the most westerly prairies. In the bared areas the plants occurred in large numbers and often reached more than twice their usual stature. Like 
the following, this annual dried in June. The slightly roughened, nearly spherical seeds, are one-half millimeter or less in cliameter and appear as specks of dust.

Specularia perfoliata became extremely abundant in the eastern half of the area. Plants were often grouped in large numbers and grew and branched in an unusually vigorous manner. The seeds are very minute, flat, disk-shaped bodies, appearing like small specks of dust. They are produced in great abundance and easily carried by wind.

Many bulbous plants such as Allium mutabile, Erythronium mesochoreum, and Anemone caroliniana occurred in unusual abundance and flourished during 1935. Of greatest abundance among these was Oxalis violacea. It was found commonly to very abundantly in most of the drought-injured prairies, often occurring in great abundance in areas where the dead grass left the soil bare. Hedeoma hispida and I'lantago purshii were scattered more or less abundantly over the bared and semibared areas in nearly all of the prairies. Formerly they were found nearly always in association with the short grasses only. The seeds of Hedeoma are small, light and readily distributed by the wind.

Other forbs that were of unusual local abundance in a few of the prairies were Artemisia gnaphalodes, Solidago glaberrima, Gaura parviflora, and Achillea occidentalis. They were sometimes practically the only species surviving over considerable tracts.

\section{SeEdLings}

Careful note of the chief seedlings of prairie plants was made during 1935. Seedlings of Erigeron ramosus were by far the most abundant, easily exceeding those of all other species combined. By the beginning of the summer drought they were 6 to 7 inches tall. Seedlings of Koeleria cristata ranked second, with an abundance of those of Aster muitiflorus, Kuhnia glutinosa, and various goldenrods, in order. Those of legumes such as Amorpha canescens, Astragalus crassicarpus, and Psoralea floribunda were much less common. The dry spring had been unfavorable to early seed germination, but after May 15 moisture was plentiful.

\section{INVASION BY RUDERALS}

Certain ruderals, normally not found in prairies, were widely distributed. Lepidium virginicum was common to abundant throughout nearly all of the prairies where death by drought resulted in enough light for ecesis. This weed was often a fairly good indicator of the amount of bared space. Seeds were borne in such abundance that they literally covered the soil beneath densely aggregated plants. They are flat, about a millimeter long, slightly less in width, and easily carried by the wind. Peppergrass was found widely distributed in 1935 from the Missouri River to the Rocky Mountains of Colorado and far into Wyoming. 
Leptilon canadense was common to abundant in the prairies of the eastern half of the area and in some more westerly ones. The plants were frequently 2.5 to 3.5 feet tall. In pastures they formed veritable thickets which greatly delayed one's progress.

Bromus secalinus occurred in very great abundance in the western part of the area where it frequently covered hillsides in the drought-stricken prairies. Bromus tectorum also occurred in moderate amounts but mostly eastward.

Tragopogon pratensis varied from great abundance (fig. 7 ) to widely scattered plants, occurring most abundantly eastward. Salsola pestifer, conversely, was confined largely to the western part. Helianthus annuus, Solanum rostratum, and Hordeum pusillum were also common to abundant weeds in prairies westward. Amaranthus retroflexus and Lactuca scariola were usually more abundant in the eastern Nebraska prairies.

\section{Studies in the Mixed Prairie}

Studies of the environmental factors and the structure of the mixed prairie of west-central Kansas were begun before the advent of the great drought. They were continued until the end of 1935 . Intensive investigations have been pursued in a tract of 750 acres of unbroken prairie belonging to the Fort Hays Kansas State College. The exclosures, instrument stations, etc., were located about 2.5 miles west of Hays. These prairies cover a rolling topography adjacent to the valley of Big Creek, a branch of the Smoky Hill River. The elevation is about 2,100 feet, the level hilltops rising about 200 feet above the valley floor.

\section{Types of Vegetation}

Three general types of vegetation are common, with varying degrees of intermixtures. The most extensive is the little-bluestem type which occupies the hillsides and extends across shallow ravines. It extends over the brows of the hills and far beyond where the slopes continue, but gives way more or less abruptly to short grasses on the level uplands (fig. 24). The big-bluestem type is much more limited in extent. It occupies the deeper ravines, lower portions of gentle slopes, and well watered lowlands. The short-grass type is found widely distributed over the nearly level uplands. Smaller areas and strips also occur at the bases of hills, especially on south-facing slopes, where the soil is underlaid with an impervious clay.

Numerous grasses beside the dominant are found regularly in the littlebluestem areas. Andropogon furcatus, Panicum virgatum, and Bouteloua curtipendula extend far up the hillsicles. They are more or less replaced in drier situations near the brows of the hills by Sporobolus pilosus, Bouteloua hirsuta, and $B$. gracilis. Distribution of the little-bluestem type is largely controlled by the shallow soil above the underlying imestone. On the nearly 
level uplands, where a mature soil profile has developed, it is replaced by the short-grass type. On the lowlands, where deep alluvial soil is moistened by run-in water, little bluestem is replaced by the taller grasses.

Chief associates of the big bluestem are Bouteloua curtipendula, Agropyron smithii, and Sporobolus asper hookeri with smaller amounts of Panicum virgatum, Elymus virginicus, E. canadensis, Sorghastrum nutans, and Carex gravida.

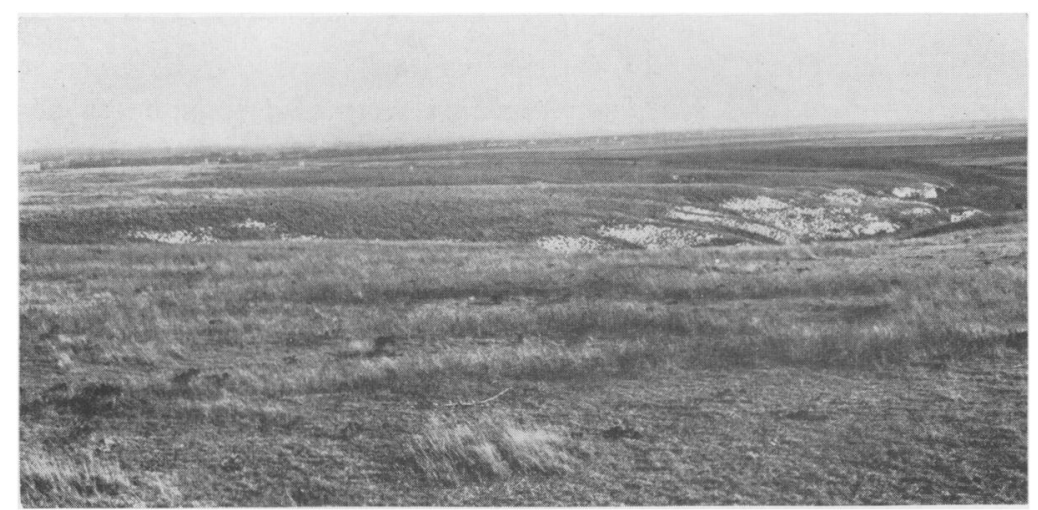

FIG. 24. General view of the mixed prairie near Hays, Kansas. The Andropogon scoparius type, which covers the slopes and occurs on the limestone outcrops, gives way on the level uplands (foreground and upper left) to the Bulbilis-Bouteloua type of vegetation.

The Bulbilis dactyloides-Bouteloua gracilis type is characterized by a predominance of buffalo grass, by blue grama grass in probably about one-third as great abundance, and by bunches of wire grass, Aristida purpurea, and little bluestem. The bunch grasses may occur as widely scattered plants, but increase in numbers with a more favorable water supply. Sitanion elymoides is a common species of much less importance.

\section{Precipitation}

The mean annual precipitation at Hays over a period of 68 years is 22.84 inches. The highest mean monthly rainfall of 3 to 3.5 inches occurs during May, June, July, and August. The dry years of 1933 to 1935 inclusive, with an average of only 15.46 inches precipitation, were preceded by 6 years (1927-32) when the mean annual precipitation of 27.76 inches was 4.92 inches above the 68 -year average. Average precipitation by months during the 68 year period, the wet period, and the drought are shown in figure 25. Data for the first two periods were supplied by Mr. A. L. Hallsted from the Fort Hays Kansas Experiment Station; that for the dry period was obtained at the prairie station 2.5 miles west of Fort Hays and 200 feet above the valley 


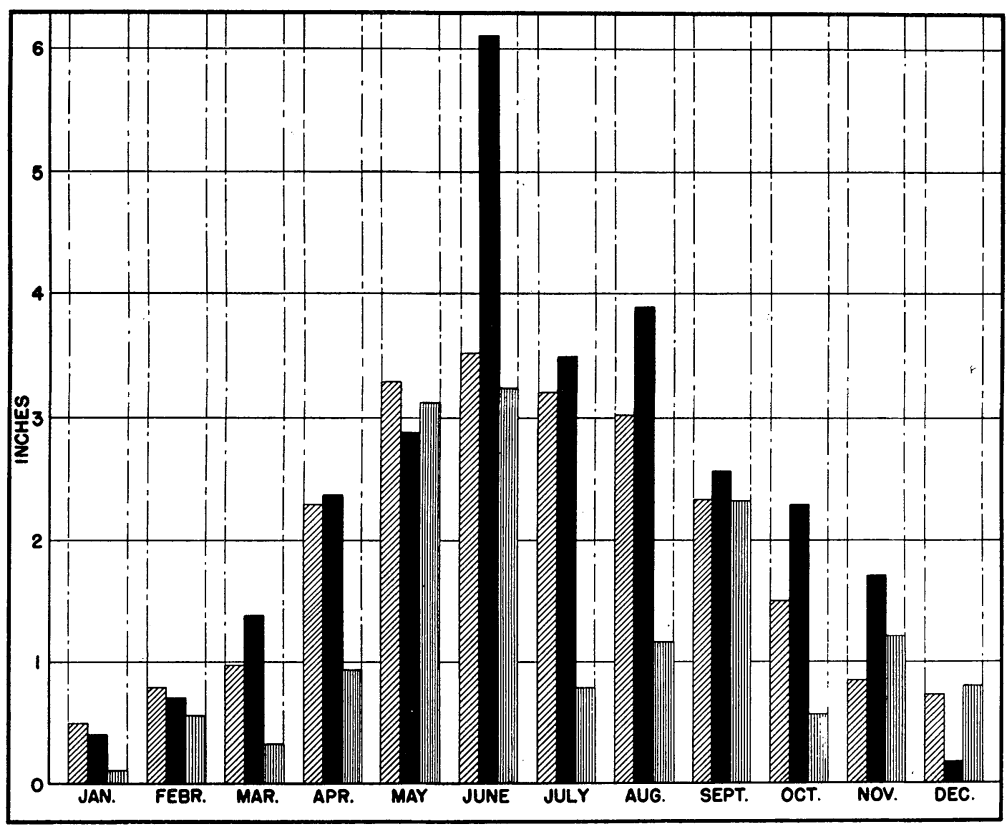

FIg. 25. Average precipitation by months at Hays, Kansas, over a period of 68 years (left hatch), from 1927 to 1932 inclusive (black), and from 1933 to 1935 inclusive (vertical hatch).

of Big Creek where the government rain gauge is located. A standard rain gauge was maintained at a height of 3 feet, and readings were taken after each shower. Precipitation by months during the three critical years is shown in table I.

TABLE I. Precipitation by months during the drought

\begin{tabular}{rrrrrrrrrrrrrr}
\hline \hline Yr. & J. & F. & M. & \multicolumn{1}{c}{ A. } & M. & J. & Jl. & A. & S. & O. & N. & D. & T. \\
\hline 1933 & .07 & .21 & .33 & 2.14 & 2.53 & .56 & 1.70 & 1.17 & 2.03 & .03 & .54 & 2.17 & 13.48 \\
1934 & .29 & 1.16 & .45 & .37 & 1.55 & 3.95 & .67 & 2.21 & 1.59 & .70 & .75 & .02 & 13.71 \\
1935 & T & .30 & .15 & .21 & 5.26 & 5.12 & .01 & 1.30 & 3.35 & .95 & 2.35 & .20 & 19.20 \\
\hline
\end{tabular}

Precipitation for 1933 totaled only 13.48 inches which was 9.36 inches below normal and 14.28 inches less than that of the favorable period just preceding. A moist spring was followed by drought in June and low rainfall during the hot summer. Conditions resulting from a very dry autumn were somewhat ameliorated by 2 inches of precipitation in December.

The spring of 1934 was extremely dry. The 1.55 inches rainfall in May was dissipated in 8 showers, only one of which exceeded .31 inch. The 3.95 inches in June included 4 rains of .42 to 1.49 inches. The 6 remaining showers were so small and widely scattered as to have practically no effect upon soil 
moisture. July had only 2 showers, .15 and .52 inch. August with 2.21 inches had only one rainy period when any but the surface inch or two of soil was moist. This was at the end of the month when 1.35 inches of water fell during a period of two days. Six widely scattered showers, none exceeding .38 inch, fell in September and netted 1.59 inches of moisture. Scattered showers in October and November totaled .70 and .75 inch, respectively. The winter was extremely dry. No precipitation fell in December. The total for the year. was only 13.71 inches.

January of 1935 had no precipitation. The highest precipitation, .30 inch, of the following three months occurred in February. It had no effect upon replenishing soil moisture. Thus from October 18, 1934, to May 11, 1935, there was no efficient precipatition. The drought was broken by good, well distributed showers beginning on May 11 and extending to June 28. The total precipitation for May was 5.26 inches, and June had 5.12 inches. No rain fell during July. Of the 5 showers in August (total 1.3 inches) only one, .52 on August 20, moistened the surface inches of parched soil. Thus seven weeks of excellent conditions for growth were followed by seven weeks of

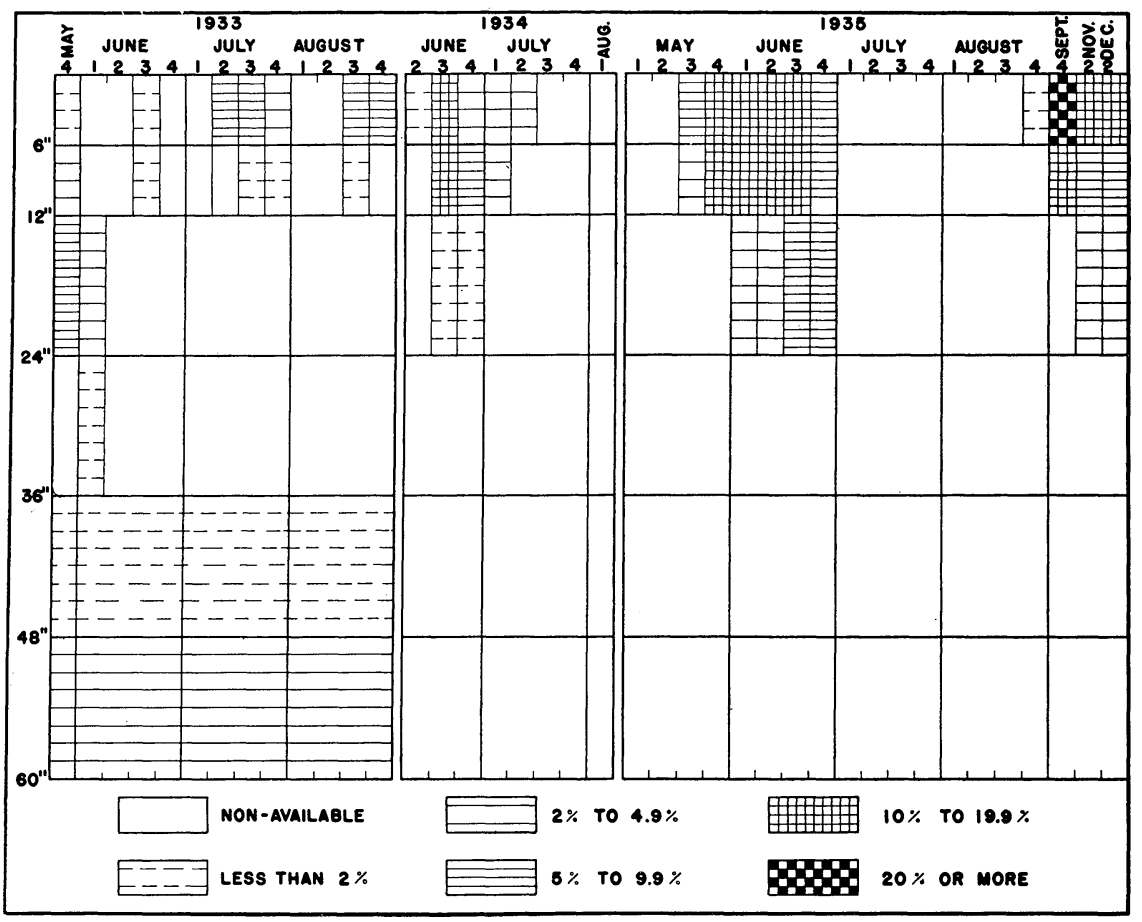

Fig. 26. Available water content of soil in the short-grass type at Hays, Kansas, at the several depths to 5 feet, during 1933 to 1935 . The hygroscopic coefficient of the soil was considered as the approximate percentage of nonavailable water for the depth at which the sample was taken. 
drought. On September 8, .95 inch of rain fell, and 2.4 inches on September 26 , furnishing a total rainfall of 3.35 inches for the month. The fall and early winter months were moderately moist and some moisture accumulated in the surface soil. Precipitation for the year was 19.2 inches.

\section{Water Content of Soll}

The soil moisture relations have been determined during 2 to 3 years in each of the three types of vegetation. Duplicate samples in the short-grass and big-bluestem types were taken regularly to a depth of 5 feet. Owing to the presence of underlying limestone, sampling with the geotome in the littlebluestem type was confined to 2 feet in depth. Samples in the soil pockets between the rocks were also taken, but irregularly.

Water relations in the short-grass soils are shown in figure 26 . Here it may be seen that following a moist spring the June drought resulted in complete exhaustion of water available for growth from 1 to 3 feet. Although

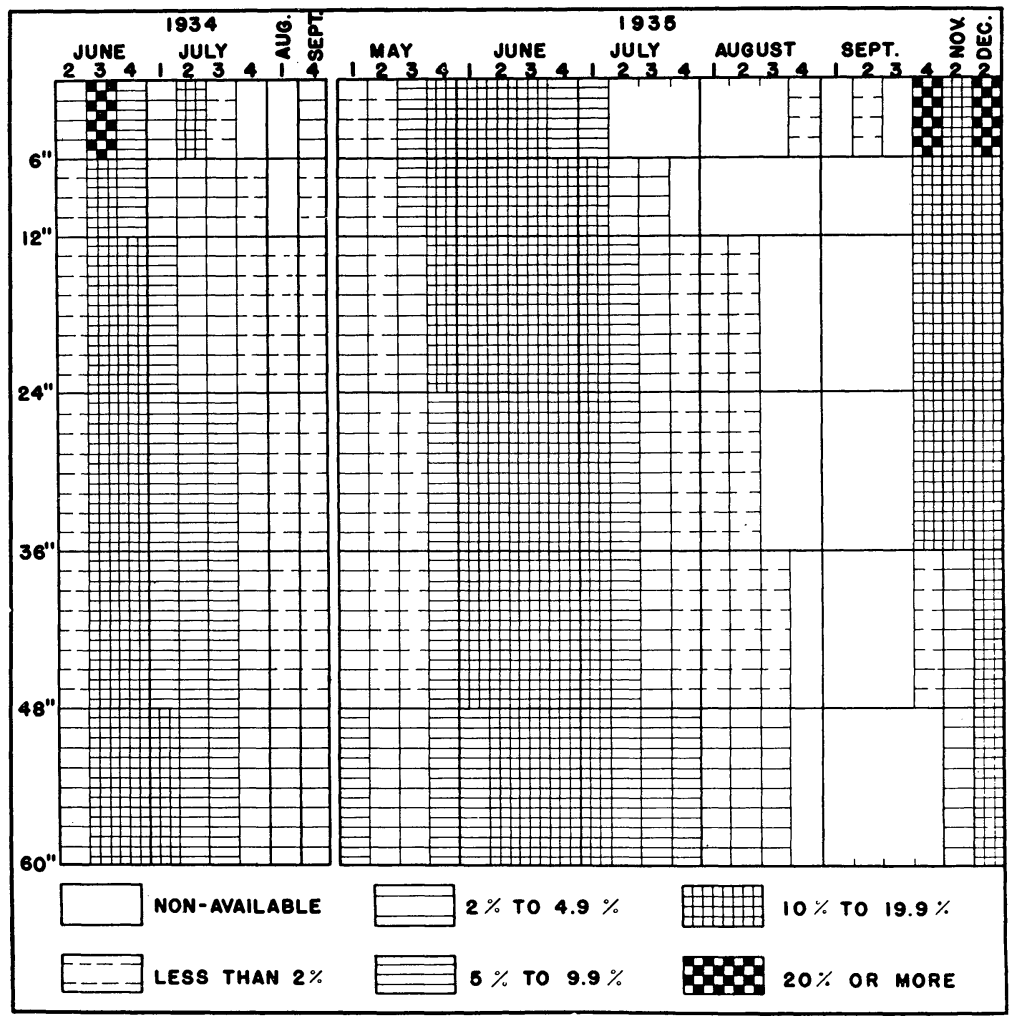

FIG. 27. Available water content of soil in the big-bluestem type at Hays, Kansas a the several depths to 5 feet, during 1934 and 1935. 
the deeper subsoil remained moist ( 1 to 5 per cent), only intermittently was water available in the surface foot. By the second week of the following June water was nonavailable at any depth except in the surface 6 inches. Then the surface foot of soil was supplied with a low water-content during 3 to 4 weeks and the second foot for only 2 weeks. The subsoil remained dry. During 1935 the soil was moist from the third week in May until the first of

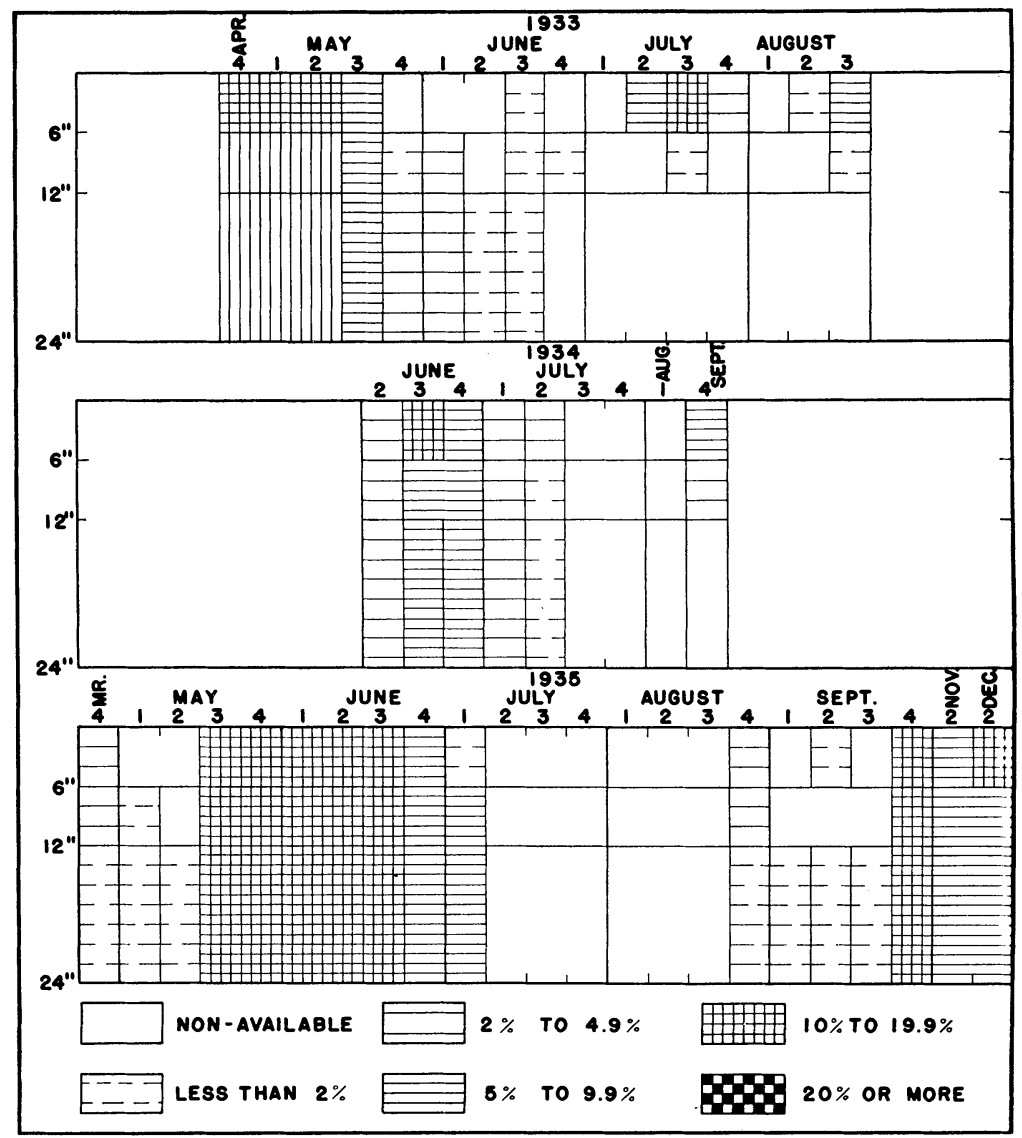

FIG. 28. Available water content of soil in the little-bluestem type at Hays, Kansas, to the underlying rock at a depth of two feet.

July. No soil moisture was available during July and practically none in August. Rains in September and later moistened the surface two feet.

In the lowland, big-bluestem habitat, soil moisture was available, although at some periods in small amounts, during the entire growing season of 1934 and until late in July of 1935 (fig. 27). An exception was nonavailable water in the first foot during late July and early August of 1934. Beginning with the second week of July, 1935, water became deficient in the surface 6 inches, 
and two weeks later this condition extended to a depth of one foot. After two more weeks no water was available to 3 feet in depth. A week later water became nonavailable at all depths, except that intermittently local showers moistened the surface. This condition continued until the last week of September, after which rains replenished both surface and subsoil moisture to a depth of 5 feet.

A fairly close relation was found between rainfall and available soil moisture of the first 2 feet in the little-bluestem type (fig. 28). Extensive studies of root distribution revealed that little bluestem drew upon soil moisture stored in the pockets and crevices of the rocks to a depth of 3 feet but big bluestem to a depth of 4 to 5 feet.

\section{Temperature and Humidity}

Thermograph records of air temperature at a height of 4 inches above the soil surface and soil temperature at a depth of 3 inches, both in the short-grass area, were obtained. These data are averaged by weeks in figure 29. During the most severe period of the 1934 drought (June 25 to August 20), the average daily maximum temperature ranged between $96^{\circ}$ arid $111^{\circ} \mathrm{F}$. The aver-

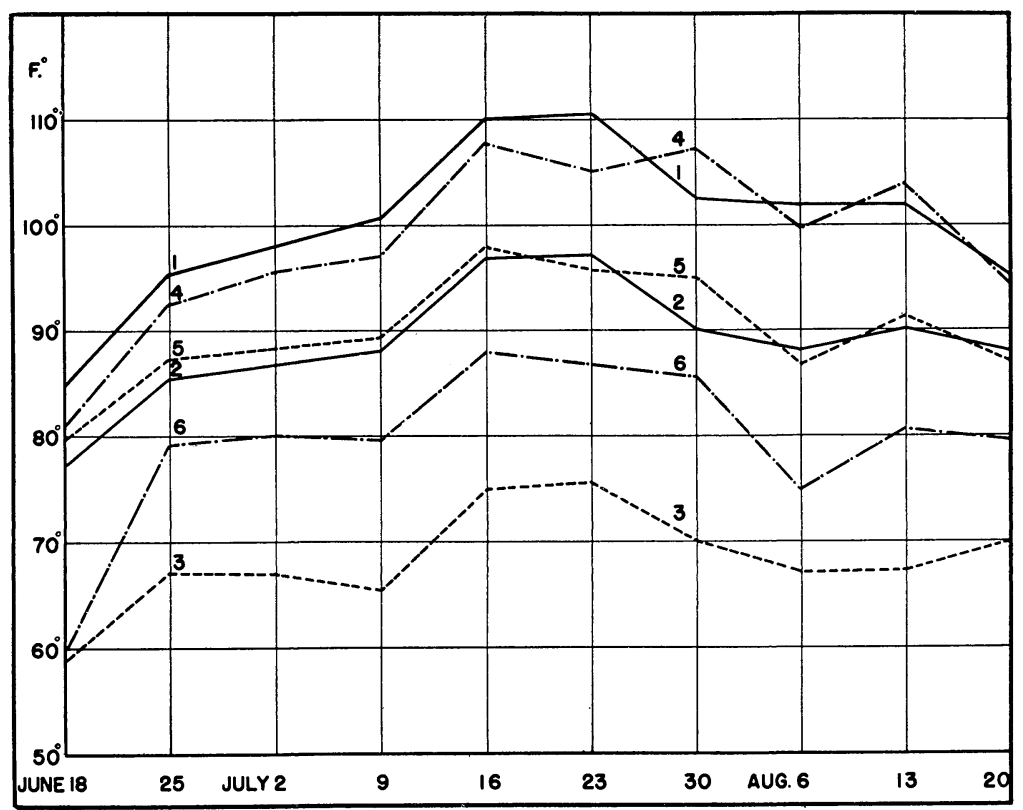

FIG. 29. Temperatures of air and soil by weeks at Hays, Kansas, during 1934. 1, Average daily maximum temperature; 2 , average day temperature (6 A.M. to 8 P.м.) ; 3 , average daily minimum temperature; 4 , average daily maximum soil temperature at 3 -inches depth; 5, average daily soil temperature; and 6, average daily minimum soil temperature. 
age day temperature varied from $86^{\circ}$ to $97^{\circ} \mathrm{F}$., and even average daily minimum temperatures were $66^{\circ}$ to $76^{\circ} \mathrm{F}$. Although these temperatures were no higher than those experienced in the tall-grass prairie at Lincoln (Weaver, et al., '35), the period of intensive heat was about two weeks longer.

Average daily maximum soil temperatures were at first slightly less than those of the air, but finally exceeded those of air temperature. Likewise, average day temperatures of soil and air did not depart widely, and average daily minimum soil temperatures were regularly $8^{\circ}$ to $14^{\circ} \mathrm{F}$. higher than those of the air.

The humidity regularly fell to 25 to 15 per cent during the afternoons, and often to 11 per cent or less. Since grasses in phytometer cans that were watered, as well as watered plants in experimental plots did not die, it is believed that the great loss of vegetation was due to drought and not directly to high temperatures. Increased temperature decreases the relative humidity which results in increasing water losses by transpiration as well as by evaporation from the surface soil. It is usual for high temperatures and drought to work together in the destruction of vegetation, but drought is usually the direct cause of death.

\section{Evaporation and Water Loss from Vegetation}

Average daily water losses by weeks from pairs of standardized, white, spherical atmometers ranged during this period of stress from 76 to $138 \mathrm{cc}$. These losses were 1.5 to 1.7 times as great as those recorded during this period in the tall-grass prairie at Lincoln.

Losses of water through transpiration and surface soil evaporation from large sod phytometers sunk 1.5 feet in the soil, each lot in its own habitat, were very high. The short grasses lost 12.2 and 8.3 pounds per square foot per week, the little bluestem 13.9 and 10.4 pounds, and the big bluestem 11.8 to 11.3 pounds per week during the third and fourth weeks in July, respectively. Losses from the little bluestem were 11 per cent greater than from similar unit areas at Lincoln.

\section{The 1935 Drought}

Brief note of environmental conditions during 1935 is necessary in order that the excellent early growth, followed by severe wilting and frequently by death of the vegetation, may be understood. A series of the worst dust storms in the history of Kansas occurred during the late winter and spring of 1935 (fig. 30). Hot, desiccating winds of high velocity occurred commonly during the summer. The moderate temperatures of spring and early summer were followed by average daily maximum air temperatures of $98^{\circ}$ to $104^{\circ} \mathrm{F}$. during the almost rainless months of July and August. Soil temperatures likewise reached nearly $100^{\circ} \mathrm{F}$. Average day humidity decreased rapidly from 74 to 78 per cent in June to 44 to 57 per cent. From the middle 
of July to August 20, average daily minimum humidity ranged between 21 and 29 per cent. Average daily evaporation losses by weeks increased from the 12 to $30 \mathrm{cc}$. losses of June, to 65 to $83 \mathrm{cc}$. during this period of heat and drought. Losses of water from phytometers were very high.

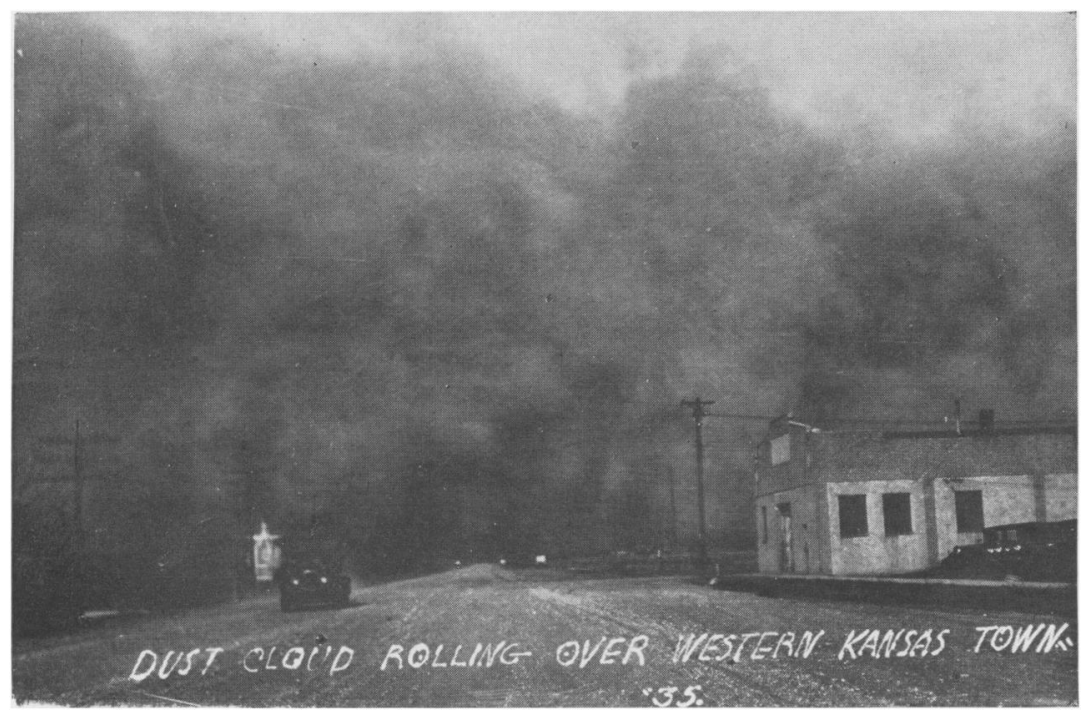

FIG. 30. Dust cloud rolling over a west-central Kansas town. Photo by Potter, Ness City, Kansas.

\section{EFfect UPon the Vegetation}

The changes in the cover of vegetation have been studied intensively by means of over 160 permanently established quadrats as well as by continued observation and estimates over the whole area. A very few of these quadrats, selected to show some of the various general trends in the several communities, are presented, each with a brief description of the change (figs. 31-43).

In making the quadrats, the pantograph-chart method has been employed. The short grasses and open sod of the little-bluestem type lend themselves readily to this method of study (cf. Savage, '34). The ground or basal cover represents that portion of the soil occupied by the basal cross section of the crowns, prostrate stems, and by stolons of living plants. Where such plant parts were less than one centimeter distant, the area was considered as being fully occupied. Each chart had an area of $2.25 \mathrm{sq}$. $\mathrm{dm}$., or a ratio to the length of the quadrat of 1 to 6.66. The percentage of basal cover, percentage of the cover constituted by the various species, etc., were determined from the charts by means of planimeters. 

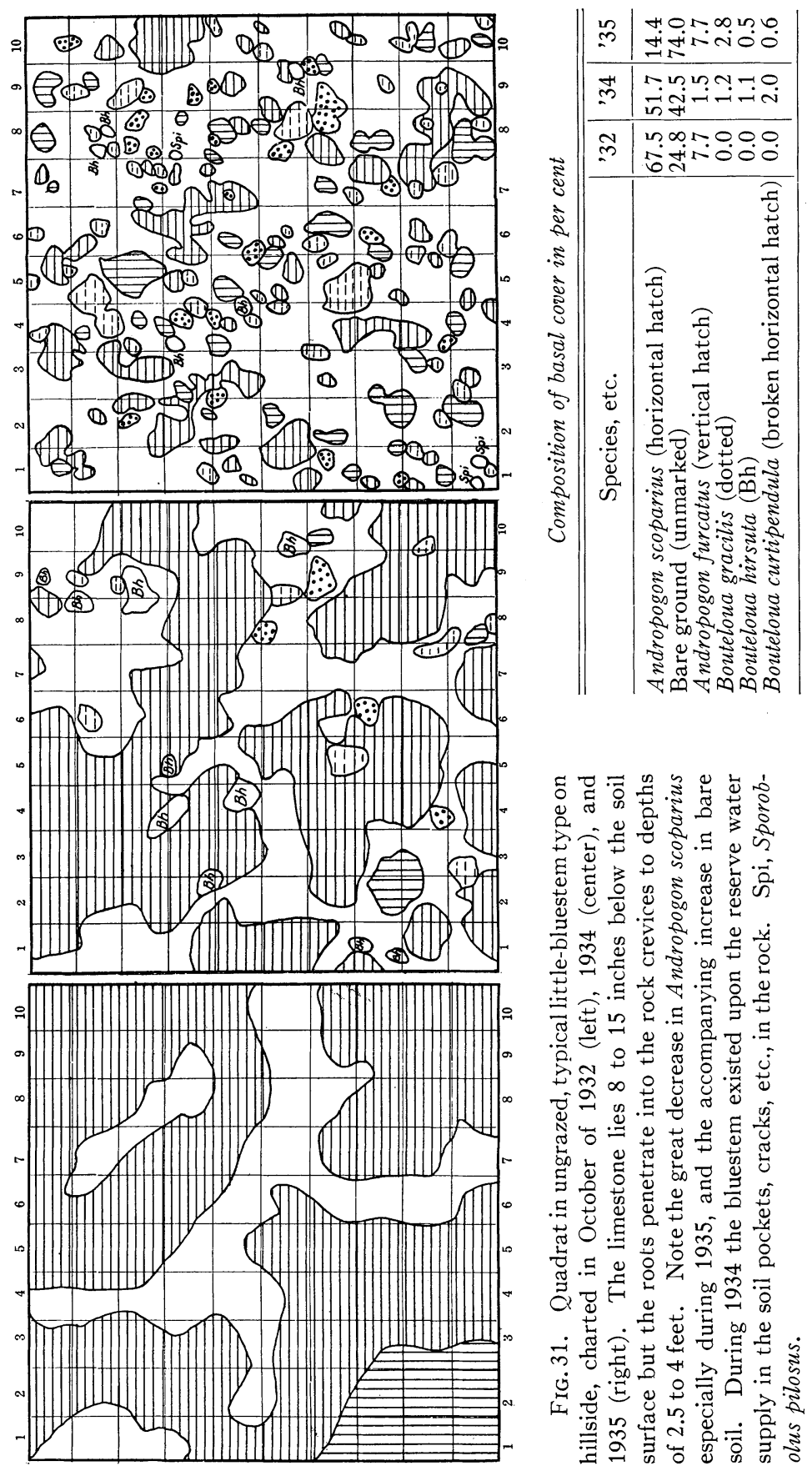


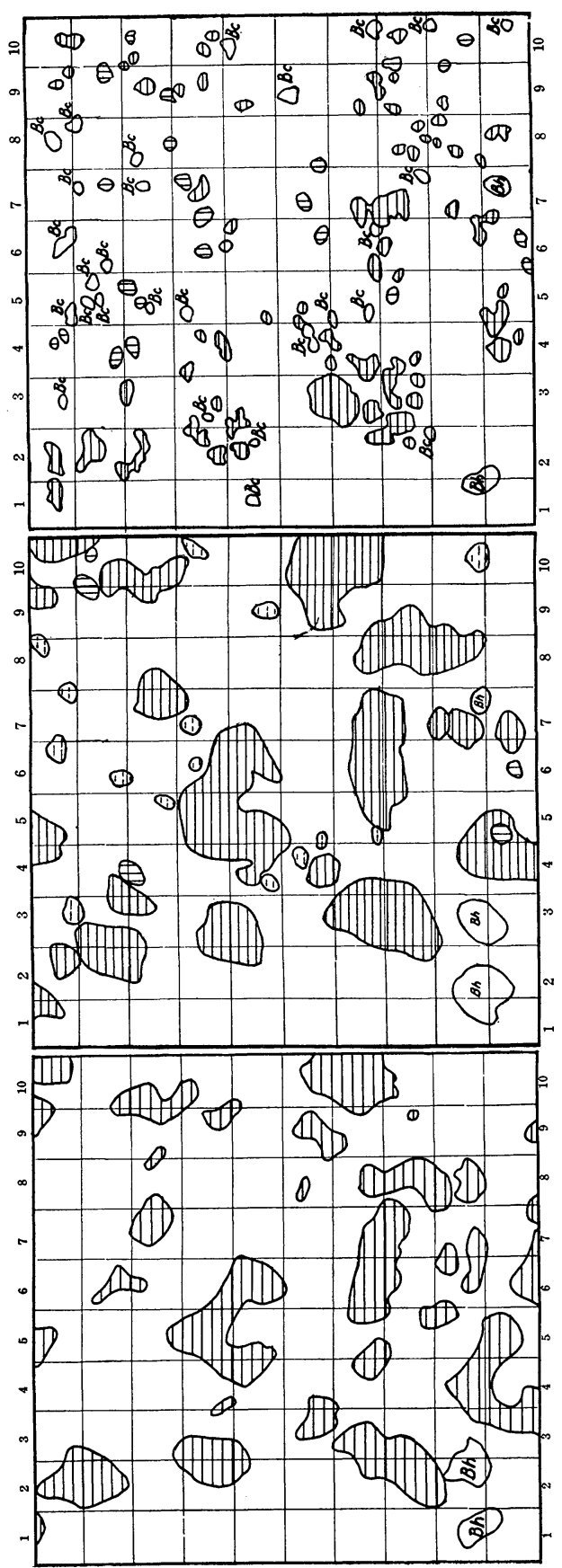

总过 导岕 芯 芯

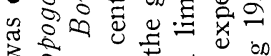

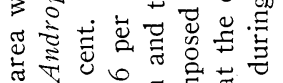

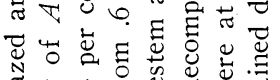

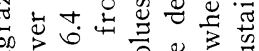

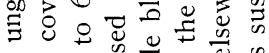

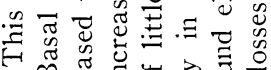

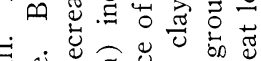
至

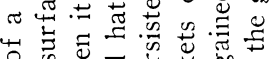

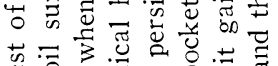

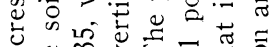

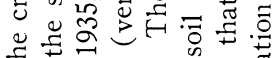

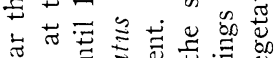

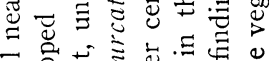

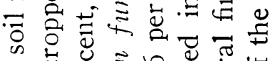

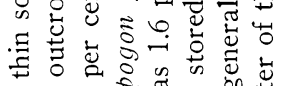
Б

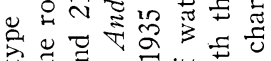

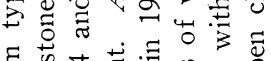

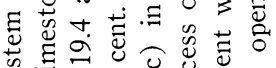
品:

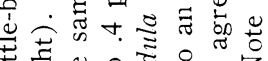

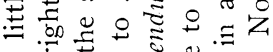

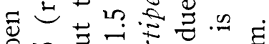

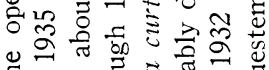

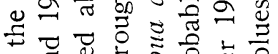

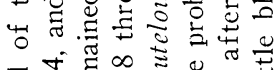

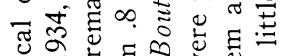
임의

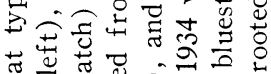

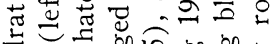

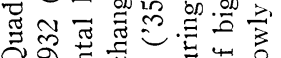

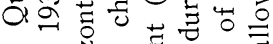

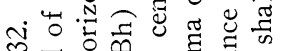

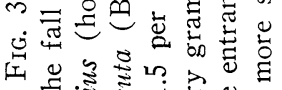
. 


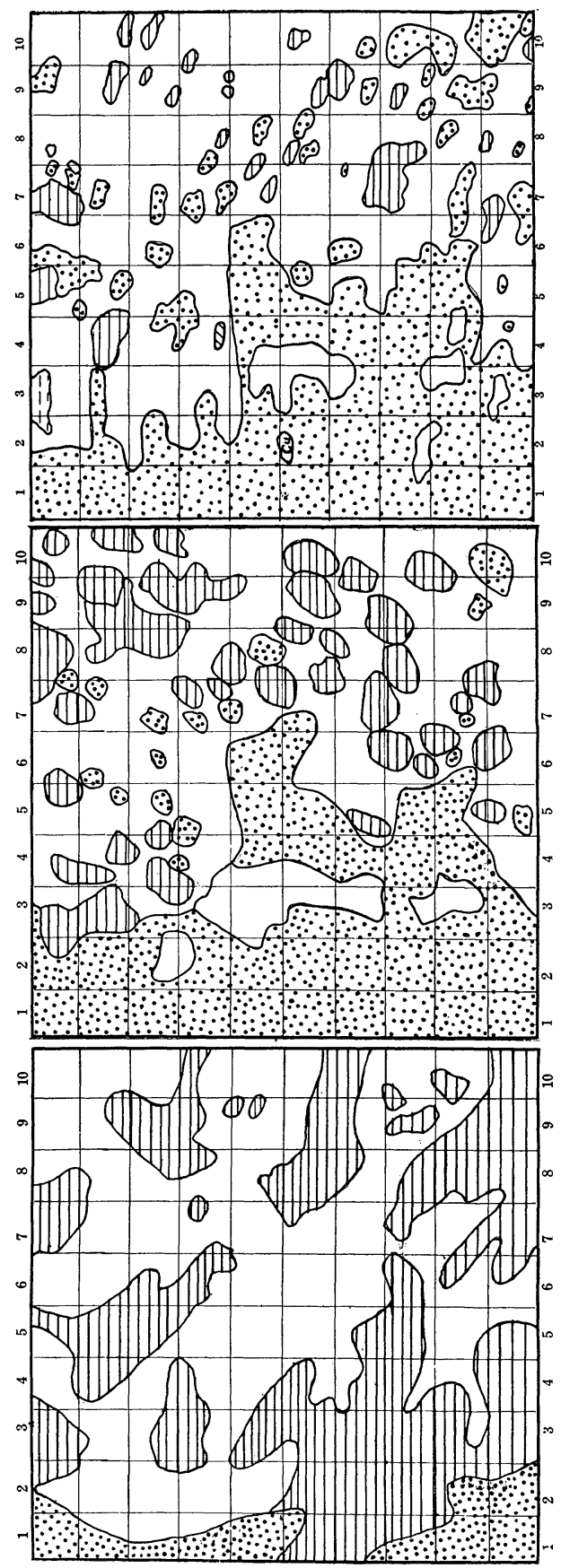

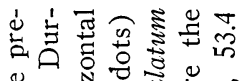

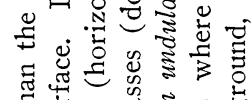
焉密

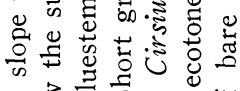

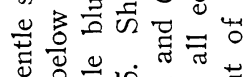

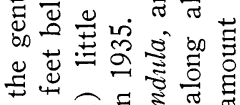

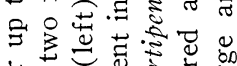

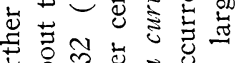

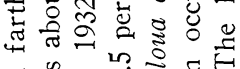

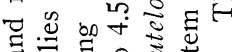

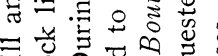

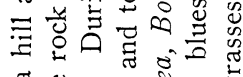

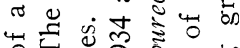
岁

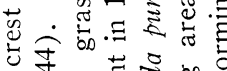

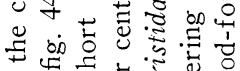

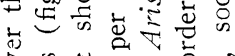

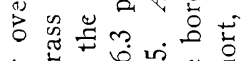

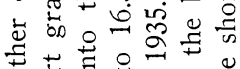
密苛.

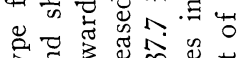

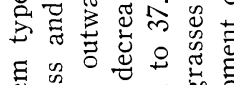
छ

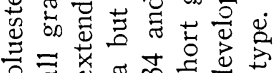

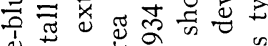

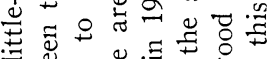

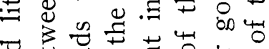

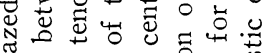

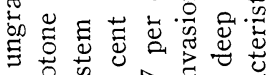

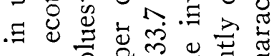

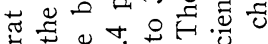
䒕

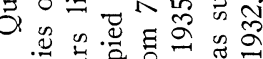

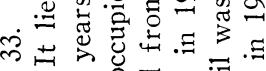

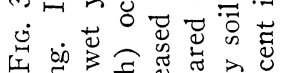

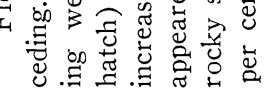




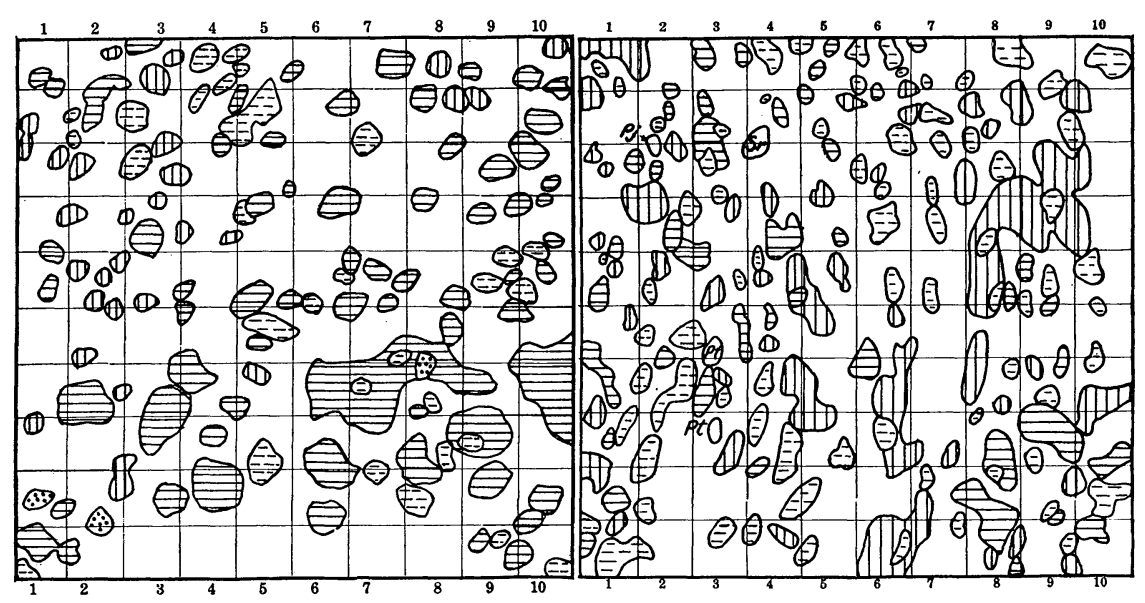

FIG. 34. Shift in grass populations in typical little-bluestem type, with a good mixture of big bluestem, as a result of drought. The local area was protected from grazing. There was some run-in water and rapid percolation among the rocks. First charting (left) in October, 1934, and second in October, 1935. Little bluestem (horizontal hatch) decreased from 17.8 to 7.6 per cent. Big bluestem (vertical hatch) increased from 3.7 to 14 per cent. Slender grama (broken horizontal hatch) increased from 5.1 to 11 per cent, but the traces of blue grama (dots) entirely disappeared. Forbs were not charted. Throughout the whole little-bluestem type, big bluestem showed smaller losses from drought than did little bluestem, and often increased at the expense of the latter as a result of its deeper root system. 

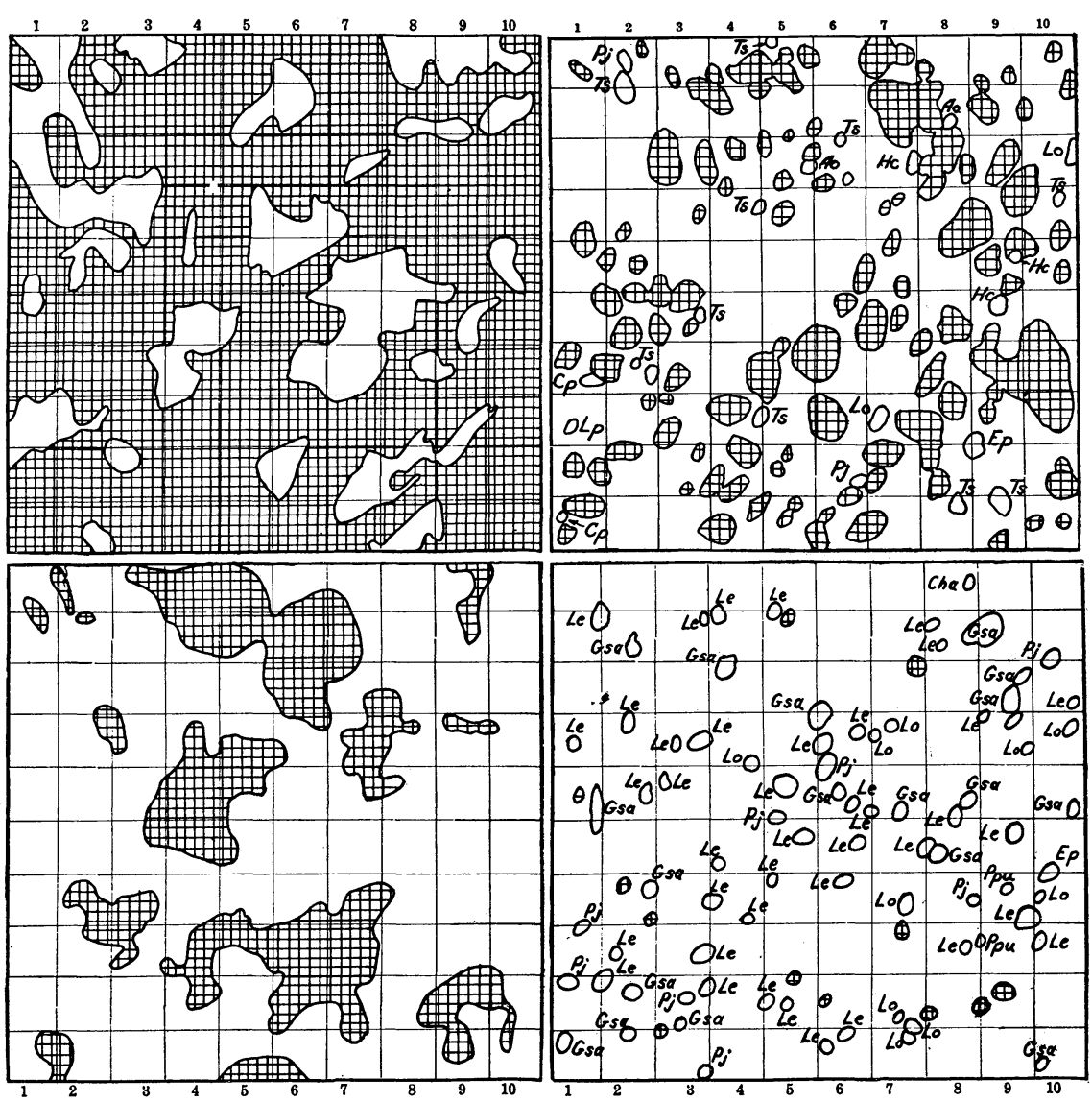

FIG. 35. Quadrat (above) in little-bluestem type on a north-facing slope in overgrazed pasture 16 miles north of Hays, Kansas. Total ground cover was 74.6 per cent (left) and total living cover was 27.1 per cent (right) in the fall of 1935. The forbs constituted only 2.1 per cent of the latter. Chief among these were Tetrancuris stenophylla (Ts) and Hymenopappus corymbosus $(\mathrm{Hc})$. The ground cover was reduced 47.5 per cent during 1935. Quadrat (below), the same, except it is on a south-facing slope. The total ground cover of tall grasses (left) was 22 per cent of which only traces (.8 per cent) remained alive in late fall. The forbs Leucelene ericoides (Le), Guticrrezia sarothrae (Gsa), Lesquerella ovalifolia (Lo), and others formed a cover of 8.3 per cent. Total loss of ground cover was 12.9 per cent during 1935. 


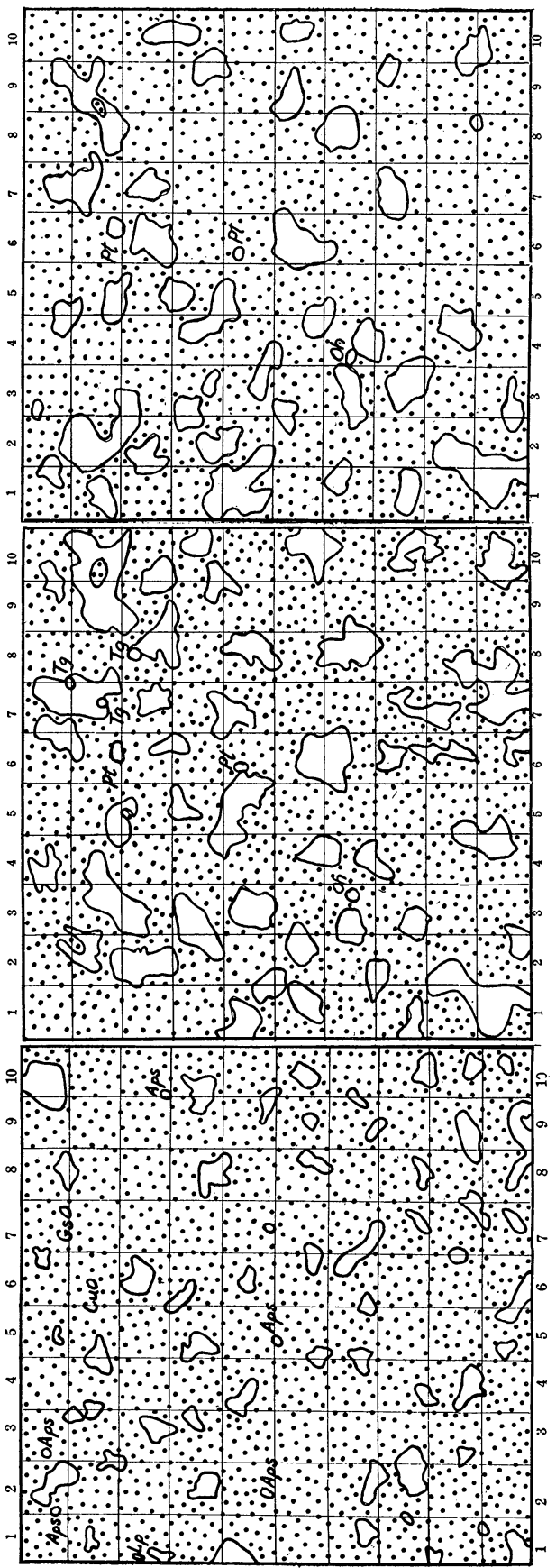

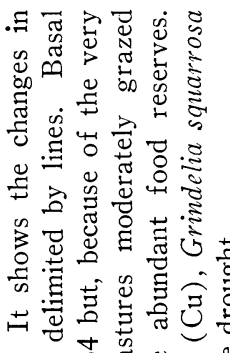

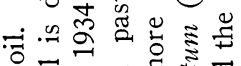

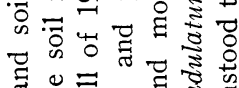

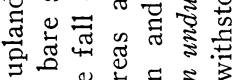

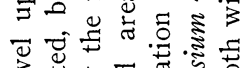

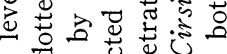

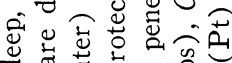

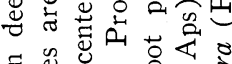

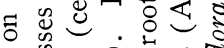

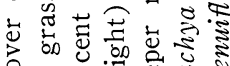

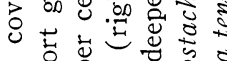

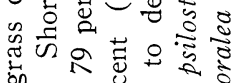

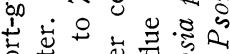

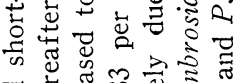

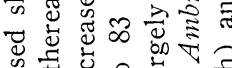

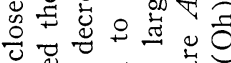

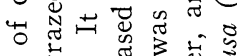

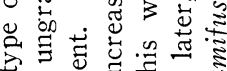

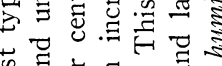

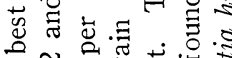
फूิ

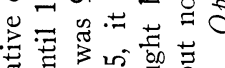

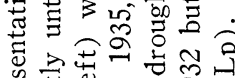

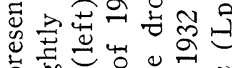

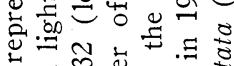
廿

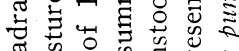

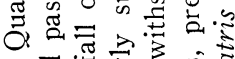

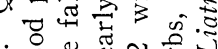

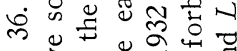

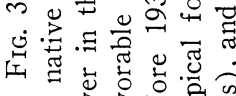

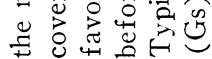




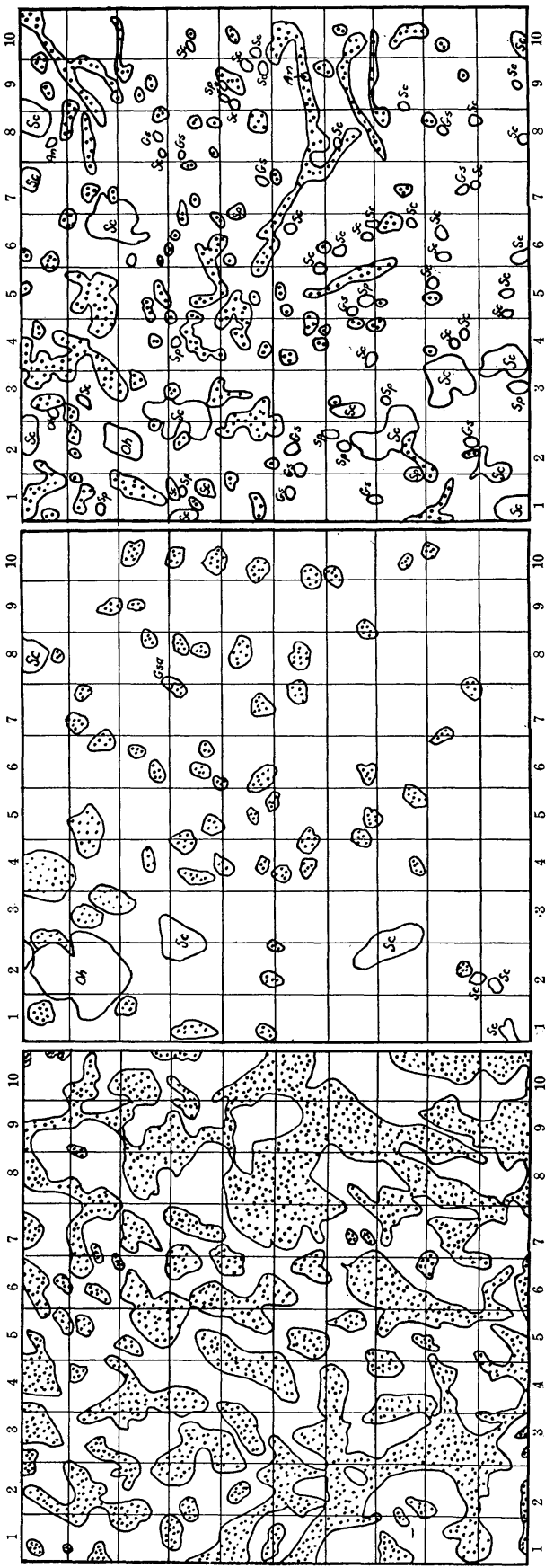

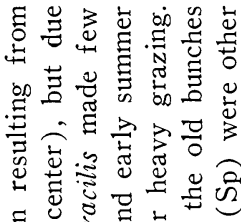

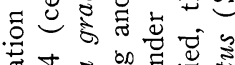

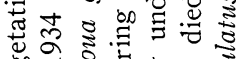

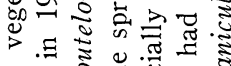

$\exists \stackrel{0}{0} \approx$

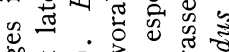

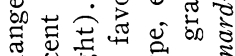

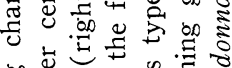

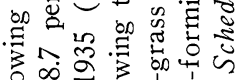

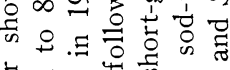

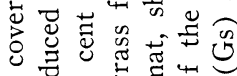

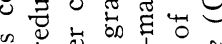

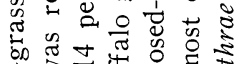

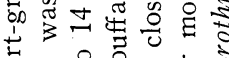

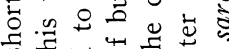
का

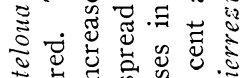

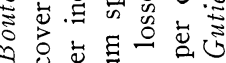

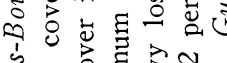

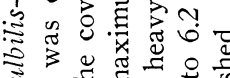
ॠ

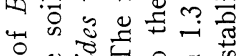

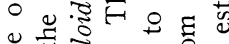

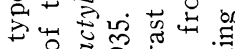

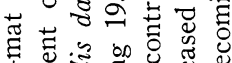
茟苛:气

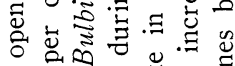
ษ .

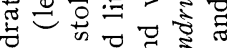

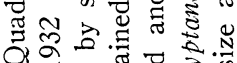

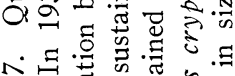

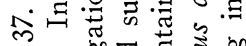

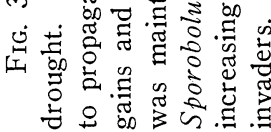




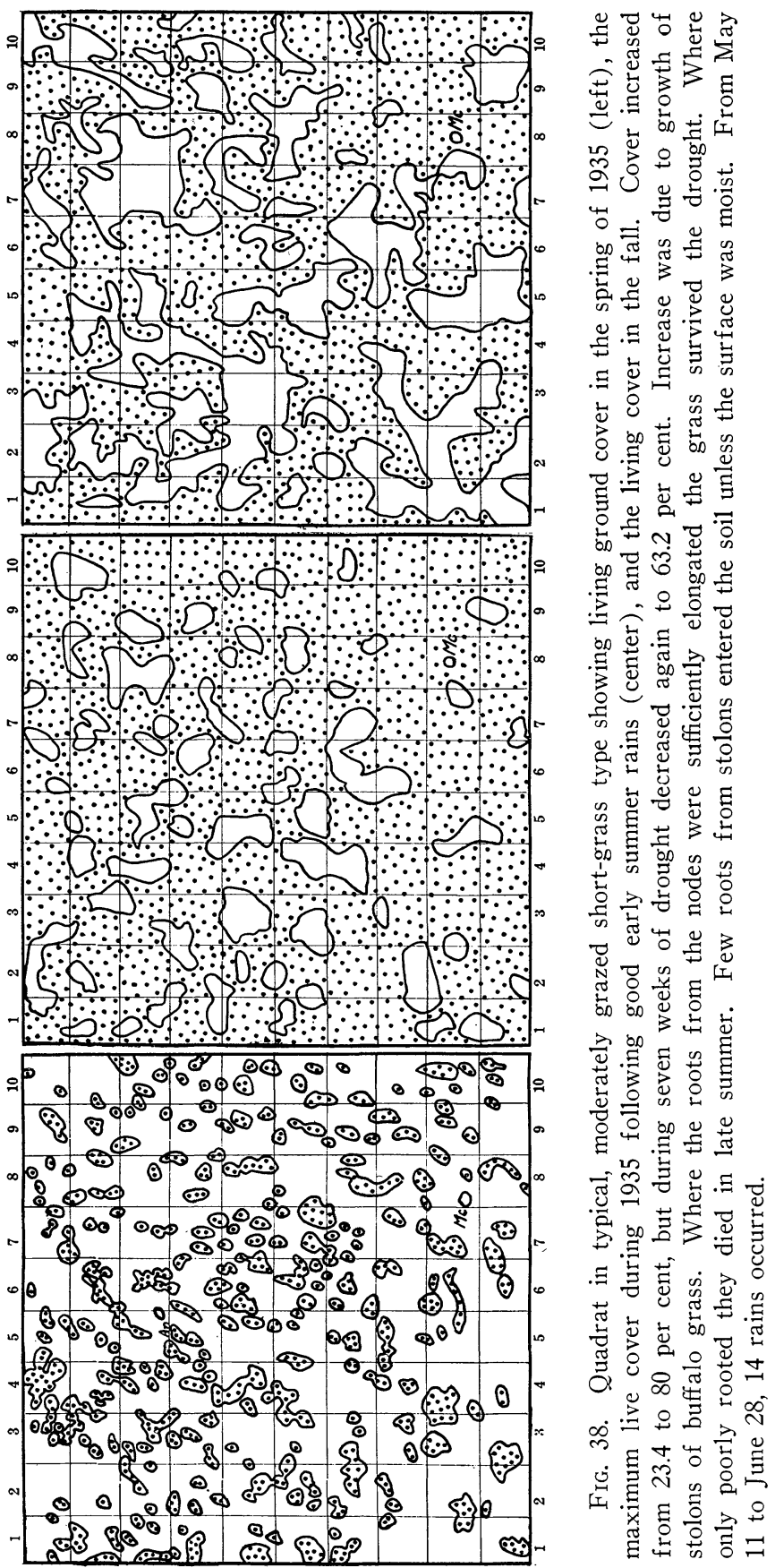



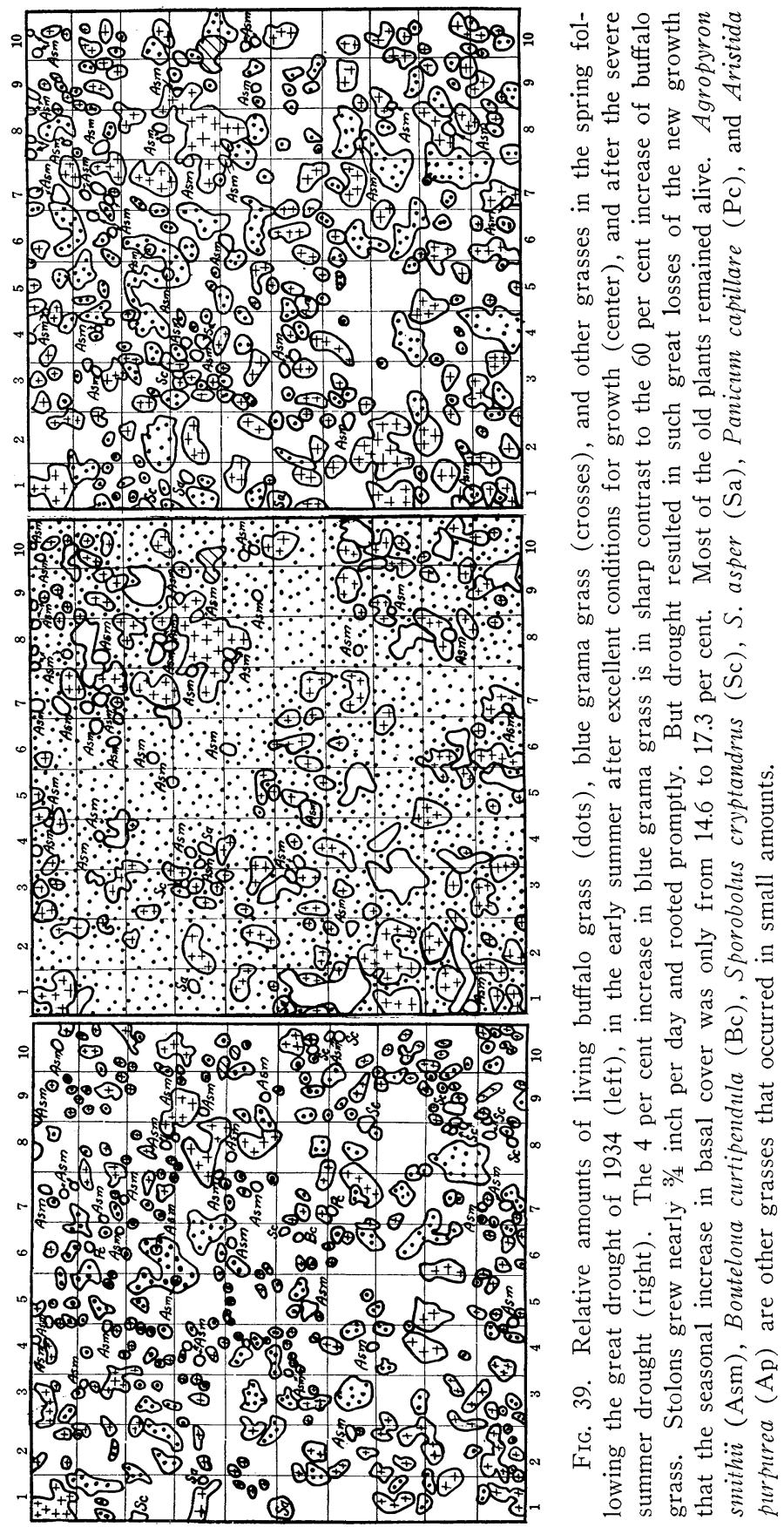

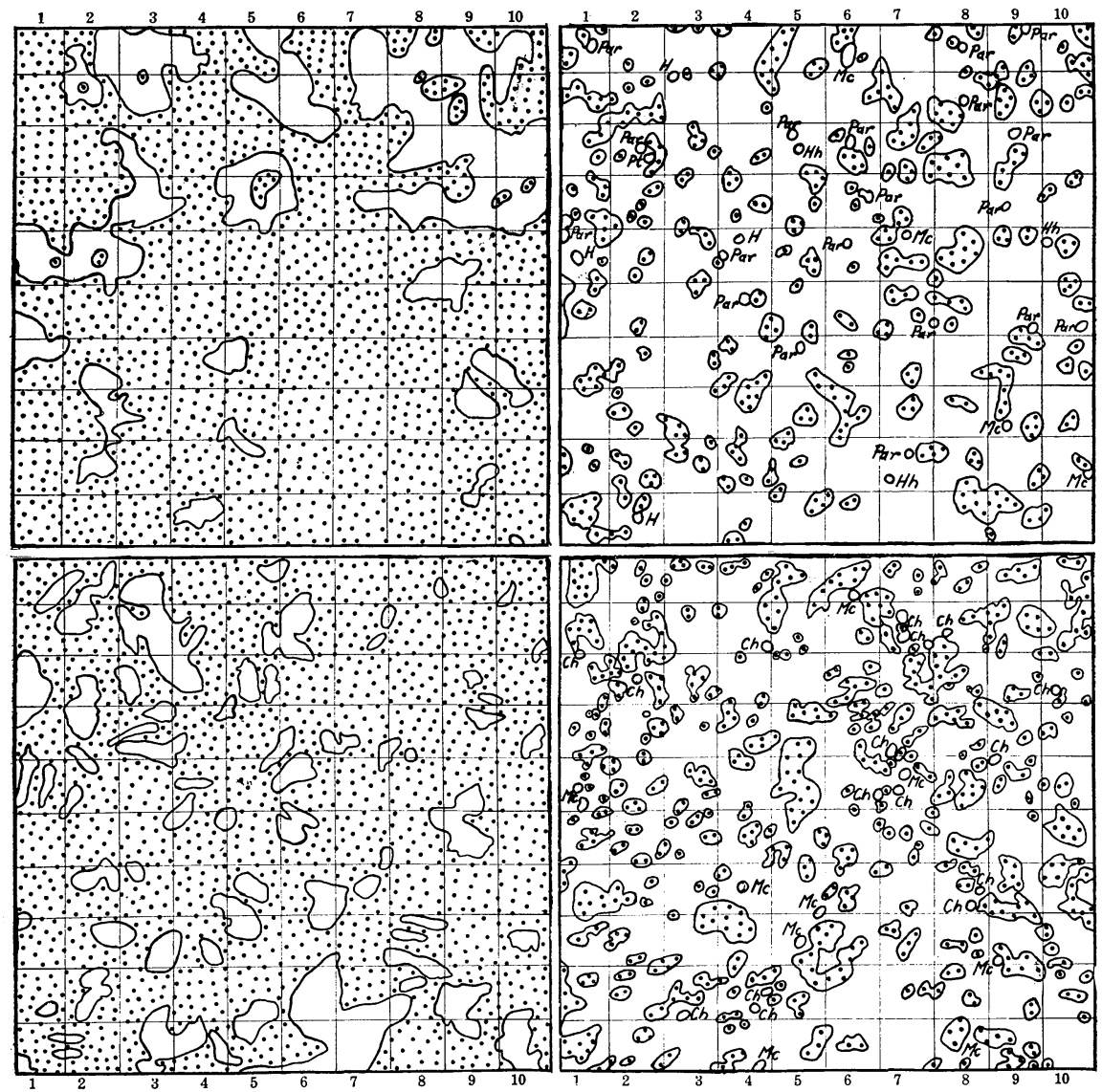

FIG. 40. Quadrat in typical closed-mat, short-grass type (dotted) showing seasonal changes in ground cover. Upper left shows total ground cover (77.5\%) during 1934. The living basal cover was reduced to 16.6 per cent (upper right) in the spring of 1935 . During the summer it increased to 80.1 per cent (lower left), but decreased to only 25.5 per cent (lower right) after the severe summer drought. Plantago aristata (Par), Hordeum pusillum $(\mathrm{H})$, Hedeoma hispida ( $\mathrm{Hh}$ ), and Maliastrum coccineum (Mc) constitute the forbs. Carex heliophila ( $\mathrm{Ch}$ ) occurred commonly after the spring rains of 1935. 


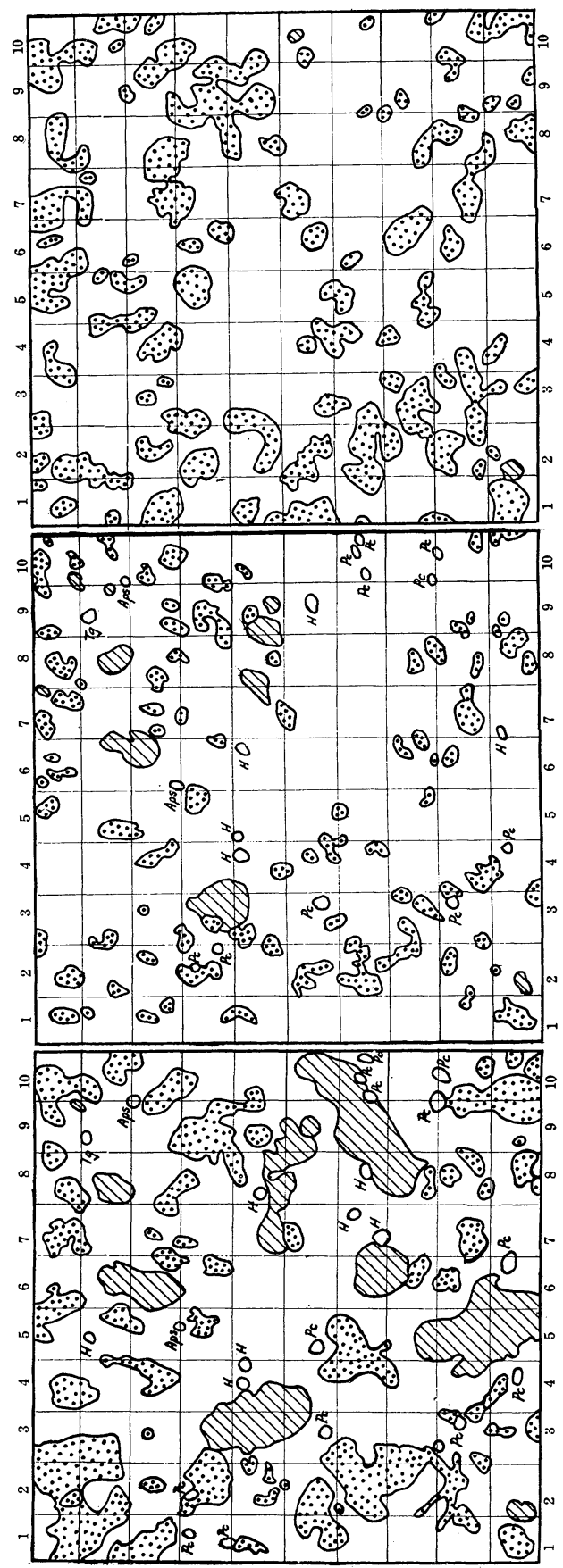

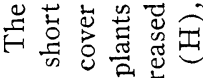

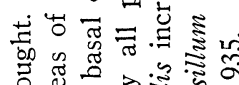

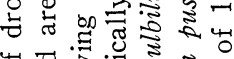

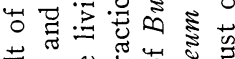

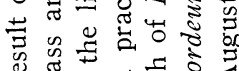

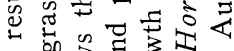
का है

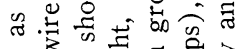

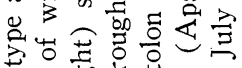

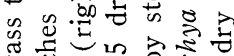
क力口

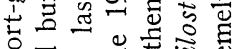
क नु

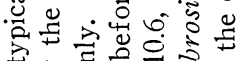
क力

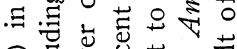
ฮิษ

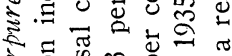

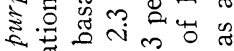
శ尹

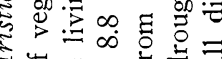

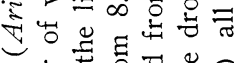

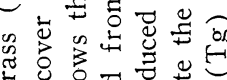

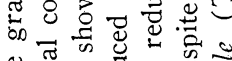

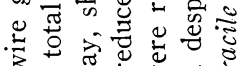

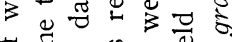

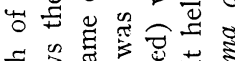

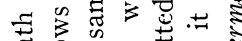

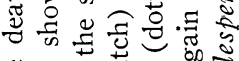

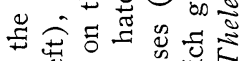
of .

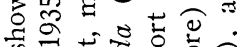

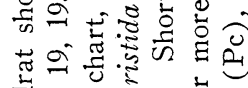

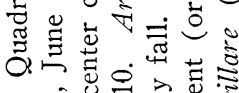
- $\dot{0}$.

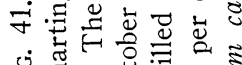

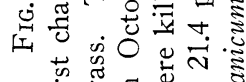

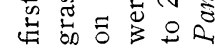




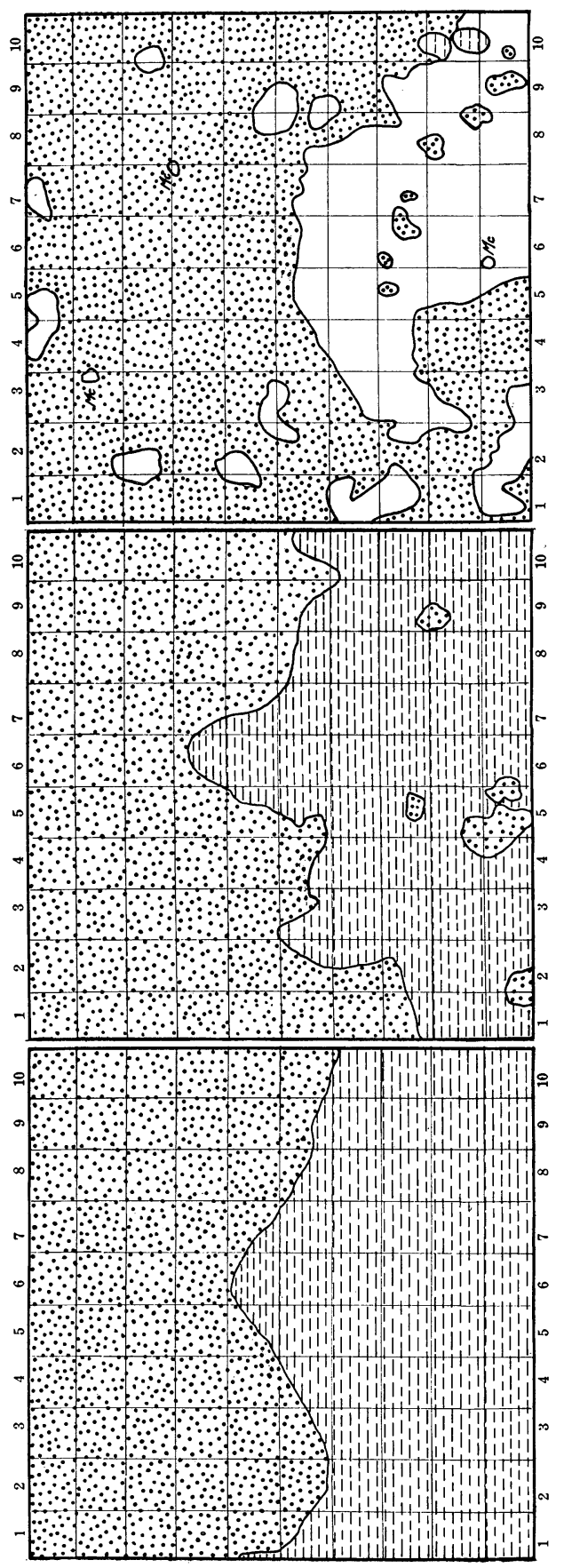

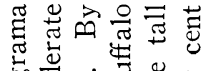

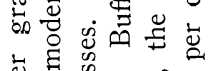

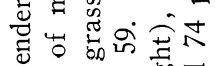

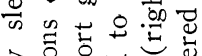

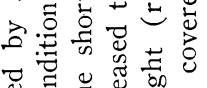

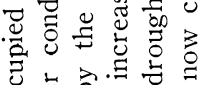

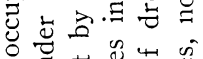

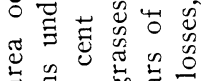

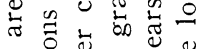
$\circ$ 范吉范

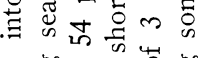

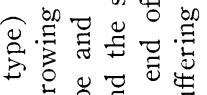

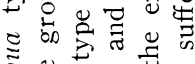

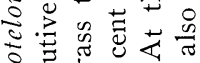

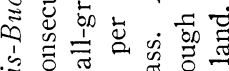

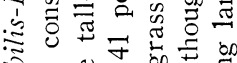
ङ

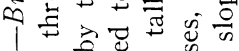

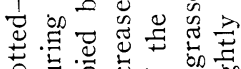

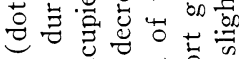
记

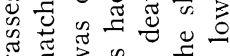

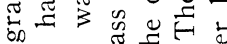

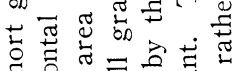
के

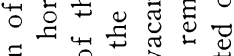

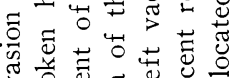

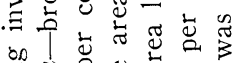

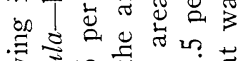

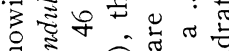
专

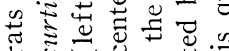

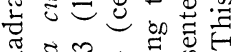

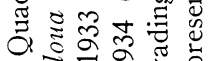
ชั ชั

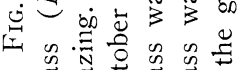

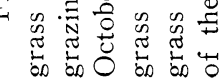



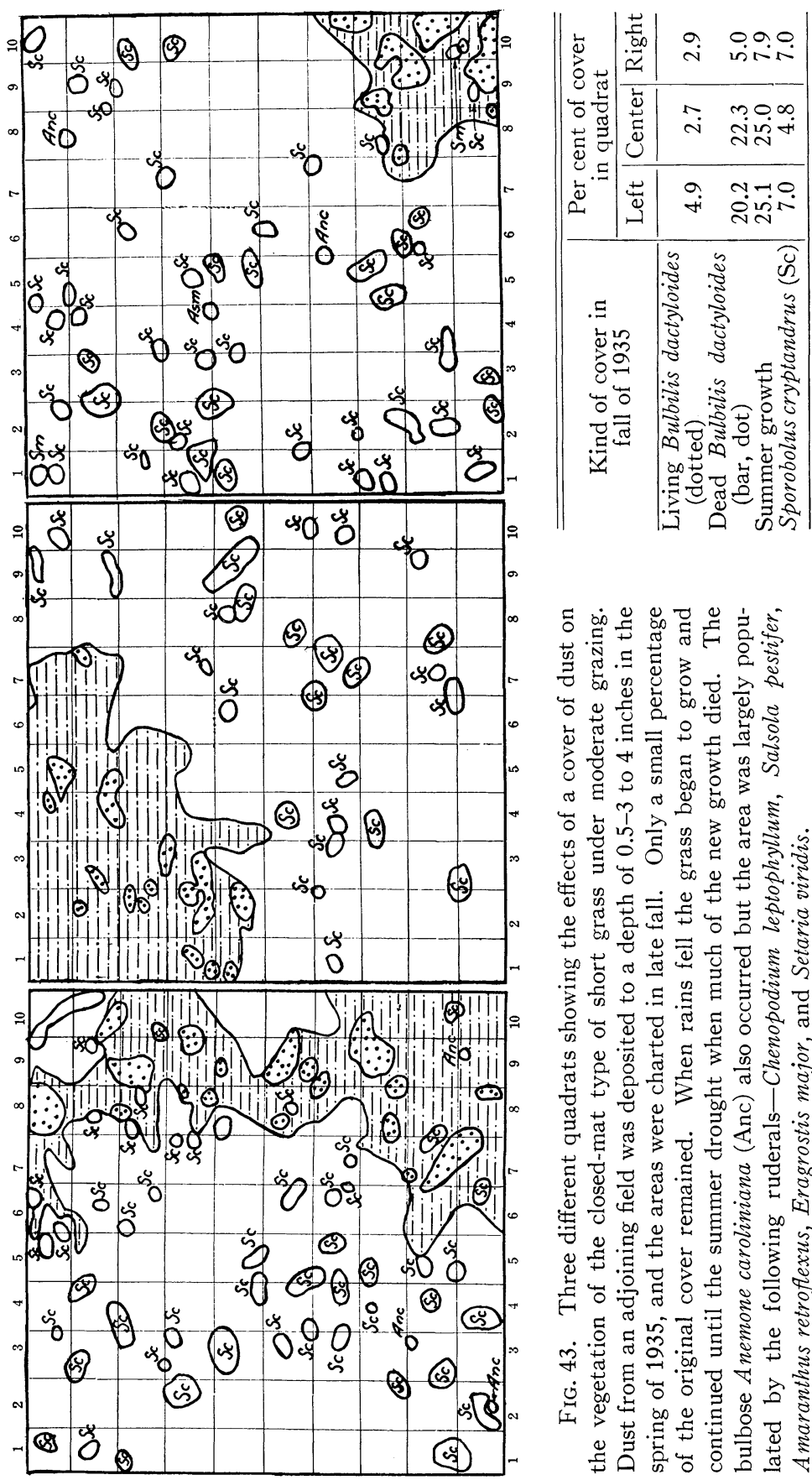

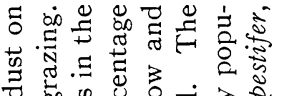

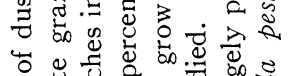

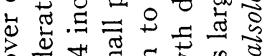

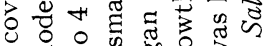

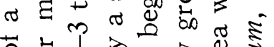

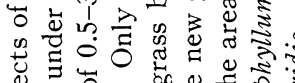
यू की

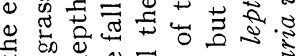

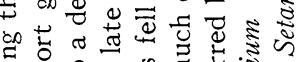

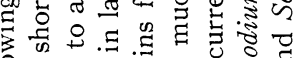

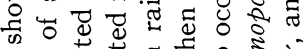

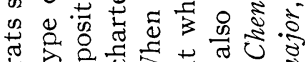

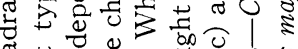

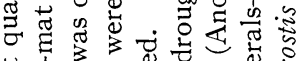

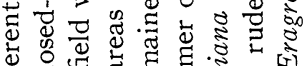

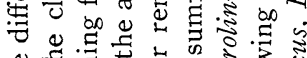
य

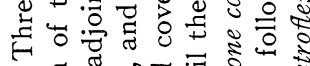
भु.

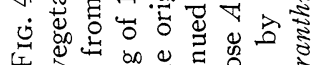

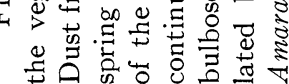




\section{Little-bluestem type}

Little bluestem suffered great losses, even when protected from grazing, especially during the drought of the second and third year when the reserve water in the pockets and crevices of the rocks was exhausted. It was replaced to some extent by big bluestem, slender grama, and species of Sporobolus, especially where these grasses were present in the mixture, but much of the soil surface was left bare. Little bluestem was handicapped by a root system which extended only 3 to 3.5 feet deep, those of big bluestem and slender grama penetrated deeper. In the ecotone between little bluestem and the short grasses, where the taller grass gradually spread outward during good years, little bluestem practically all died and much of the area was taken by buffalo grass (fig. 44). Under close grazing, good stands of mixed blue-

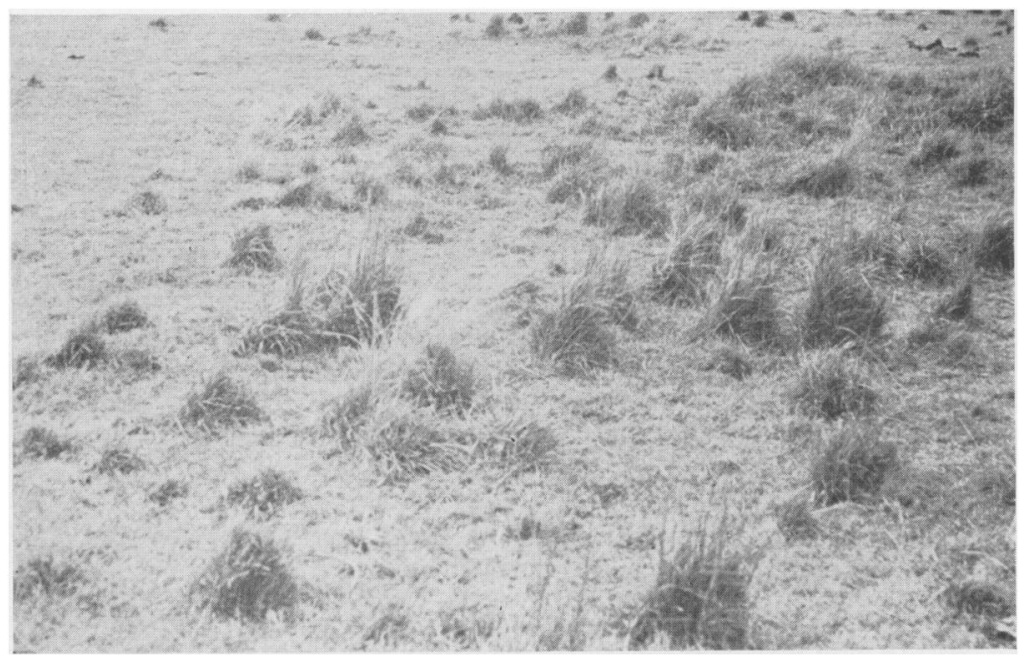

FIg. 44. Ecotone between short grasses and little bluestem on the level uplands. Practically all of the bluestem died as a result of drought.

stems on north-facing slopes decreased 66 per cent or more during 1935 alone. Almost total losses of the grass occurred on south-facing slopes.

Data from a group of 52 quadrats in the little-bluestem type are summarized in table II. All quadrats in this and following tables designated as ungrazed were lightly pastured until the spring of 1932, after which stock was excluded. The light grazing prevented the development of a maximum plant cover, which probably resulted beneficially to the plants in reducing total water transpired and in withstanding the following drought. The quadrats in the first group of 8 had a basal cover ranging from 2.5 to 70.3 per cent, which explains the relatively low average for the group. The percentage of loss was 72 . 
TABLE II. Changes in percentage of basal cover in little-bluestem type during the drought

\begin{tabular}{|c|c|c|c|c|c|c|c|c|c|}
\hline \multirow{2}{*}{ Habitat } & \multirow{2}{*}{$\begin{array}{l}\text { Number } \\
\text { of } \\
\text { quadrats }\end{array}$} & \multirow{2}{*}{ Treatment } & \multicolumn{3}{|c|}{$\begin{array}{l}\text { Ave. per cent } \\
\text { basal cover }\end{array}$} & \multicolumn{2}{|c|}{$\begin{array}{c}\text { Per cent } \\
\text { change } \\
\text { basal cover }\end{array}$} & \multicolumn{2}{|c|}{ Per cent } \\
\hline & & & 1932 & 1934 & 1935 & Gain & Loss & Gain & Loss \\
\hline $\begin{array}{l}\text { Closed type } \\
\text { Open type } \\
\text { Ecotone between tall } \\
\quad \text { and short grass } \\
\text { Ecotone between tall } \\
\text { and short grass }\end{array}$ & $\begin{array}{l}8 \\
4\end{array}$ & $\begin{array}{l}\text { Ungrazed } \\
\text { Ungrazed } \\
\text { Ungrazed } \\
\text { Moderately } \\
\text { grazed }\end{array}$ & $\begin{array}{r}35.2 \\
25.3 \\
23.0 \\
8.7\end{array}$ & $\begin{array}{r}30.9 \\
23.2 \\
\\
5.3\end{array}$ & $\begin{array}{r}9.9 \\
12.2 \\
2.7\end{array}$ & - & $\begin{array}{l}25.3 \\
13.1 \\
\\
20.3\end{array}$ & $\begin{array}{l}- \\
-\end{array}$ & $\begin{array}{l}72.0 \\
51.8 \\
88.2\end{array}$ \\
\hline & & & \multicolumn{2}{|c|}{$\underset{1935}{\text { Spring }}$} & $\begin{array}{l}\text { Fall } \\
1935\end{array}$ & & & & \\
\hline $\begin{array}{l}\text { Closed type } \\
\text { Closed type }\end{array}$ & $\begin{array}{l}3 \\
7\end{array}$ & $\begin{array}{l}\text { Ungrazed } \\
\text { Moderately }\end{array}$ & 22.9 & & 25.7 & 2.8 & 一 & 12.2 & - \\
\hline $\begin{array}{l}\text { Ecotone between tall } \\
\text { and short grass }\end{array}$ & 4 & $\begin{array}{l}\text { Moderately } \\
\text { grazed }\end{array}$ & 4.3 & & 0.3 & 一 & 4.0 & - & 93.0 \\
\hline
\end{tabular}

The vegetation in the open type withstood drought better than that on the deeper soil during 1934, because of available moisture in the clay pockets in the underlying limestone. The great loss occurred in 1935. Total loss was 51.8 per cent.

Little bluestem covered 2 to 65 per cent of the 13 quadrats in the ungrazed ecotone. Here the greater losses occurred between 1932 and 1934, since the soil was deep and there were no clay pockets with available moisture, at least within reach of the roots. 'The losses averaged 88.2 per cent. In an adjoining grazed area, where the basal cover varied from 0.5 to 25.3 per cent, the loss was 97.7 per cent. Grazing reduced the size and vigor of the little bluestem and permitted invasion of the short grasses.

Quadrats established in 1935, in little bluestem that had not been grazed for 20 years, revealed a basal cover of only 22.9 per cent. The good development during the wet years resulted in unusual transpirational losses and a thinning of the stand during 1934. A gain of 12.2 per cent was recorded during 1935. Seven moderately grazed quadrats revealed a much lower basal cover in both spring and fall of 1935, with practically no change. Farther up the hill in the ecotone, the little bluestem constituted only 4.3 per cent of the basal cover and short grasses the remainder. Competition of the short grasses for water resulted in a loss of 93.0 per cent of the bluestem. This is in agreement with the losses from the 13 quadrats in a similar area, first charted in 1932. 
Table III shows the change in the percentage of Bouteloud curtipendula, which is found rather regularly throughout the little-bluestem type. In small areas Boutelona sometimes constitutes the major portion of the plant cover. In an ungrazed, heavy cover it suffered a loss of 59 per cent. Where it constituted only 4.3 per cent of the basal cover in 1934, it made a gain of 37.3 per cent. This corresponds very closely to studies made from 1932-35. Ungrazed quadrats on thin soil underlaid with limestone gave an increase of 54.2 per cent during 1935. The partial basal cover was so low, however, that it allowed considerable experimental error. A group of 6 moderately grazed quadrats gave a loss of 98.2 per cent during 1935. These data show that, in general, slender grama survived the drought when ungrazed (except in heavy stands) but suffered severe losses when grazed. Quadrats charted

TABLE III. Change in percentage of Bouteloua curtipendula in little-bluestem type during the drought

\begin{tabular}{|c|c|c|c|c|c|c|c|}
\hline \multirow{2}{*}{$\begin{array}{l}\text { Number } \\
\text { of } \\
\text { quadrats }\end{array}$} & \multirow{2}{*}{ Treatment } & \multicolumn{2}{|c|}{$\begin{array}{l}\text { Ave. per cent of } \\
\text { basal cover }\end{array}$} & \multicolumn{2}{|c|}{$\begin{array}{l}\text { Per cent change } \\
\text { in basal cover }\end{array}$} & \multicolumn{2}{|c|}{ Per cent } \\
\hline & & 1934 & 1935 & Gain & Loss & Gain & Loss \\
\hline $\begin{array}{l}4 \\
8 \\
4 \\
6\end{array}$ & $\begin{array}{l}\text { Ungrazed heavy cover } \\
\text { Ungrazed light cover } \\
\text { Ungrazed, thin soil } \\
\text { Moderately grazed }\end{array}$ & $\begin{array}{r}72.3 \\
4.3 \\
2.4 \\
11.5\end{array}$ & $\begin{array}{r}29.6 \\
5.9 \\
1.1 \\
0.2\end{array}$ & $\begin{array}{l}\overline{1.6} \\
-\end{array}$ & $\begin{array}{r}42.7 \\
1.3 \\
11.3\end{array}$ & $\begin{array}{l}\overline{37.3} \\
- \\
-\end{array}$ & $\begin{array}{l}59.0 \\
54.2 \\
98.2\end{array}$ \\
\hline & & $\underset{1935}{\operatorname{Spring}}$ & $\begin{array}{l}\text { Fall } \\
1935\end{array}$ & & & & \\
\hline $\begin{array}{l}3 \\
7\end{array}$ & $\begin{array}{l}\text { Ungrazed } \\
\text { Moderately grazed }\end{array}$ & $\begin{array}{l}1.7 \\
8.0\end{array}$ & $\begin{array}{l}4.1 \\
8.3\end{array}$ & $\begin{array}{l}2.4 \\
0.3\end{array}$ & - & $\begin{array}{r}141.1 \\
3.7\end{array}$ & - \\
\hline
\end{tabular}

in the spring and fall of 1935, showed gains of 141 per cent when ungrazed and even 3.7 per cent where moderately grazed on a north-facing slope.

Andropogon furcatus is scattered thinly throughout the little-bluestem type. Five quadrats charted in the fall of 1932 and again in the fall of 1935 showed no change, the basal cover afforded by the big bluestem being 7.8 per cent at both times. The area was ungrazed. In 1934, however, the cover had decreased to 2.4 per cent. These data are in agreement with general observations that big bluestem decreased from 1932-34, but increased at the expense of little bluestem during the summer of 1935 .

\section{Short-grass type}

The best type of closed short-grass cover, protected from grazing during the drought, showed relatively small losses (10-20\%) although certain native 
forbs entirely disappeared. But in the open-mat type, on less favorable soil, often four-fifths of the cover was lost during 1934 but some of it was regained and maintained during 1935 (fig. 45). Where the short-grass cover had been greatly depleted in 1934, numerous small areas of living plants occurred everywhere. From these sprang stolons of buffalo grass which rapidly and rather completely reclaimed the area in May and June of 1935. Losses of the new growth, following the ensuing drought, varied from 20 to 95 per cent, depending upon type of soil and its available supply of water.

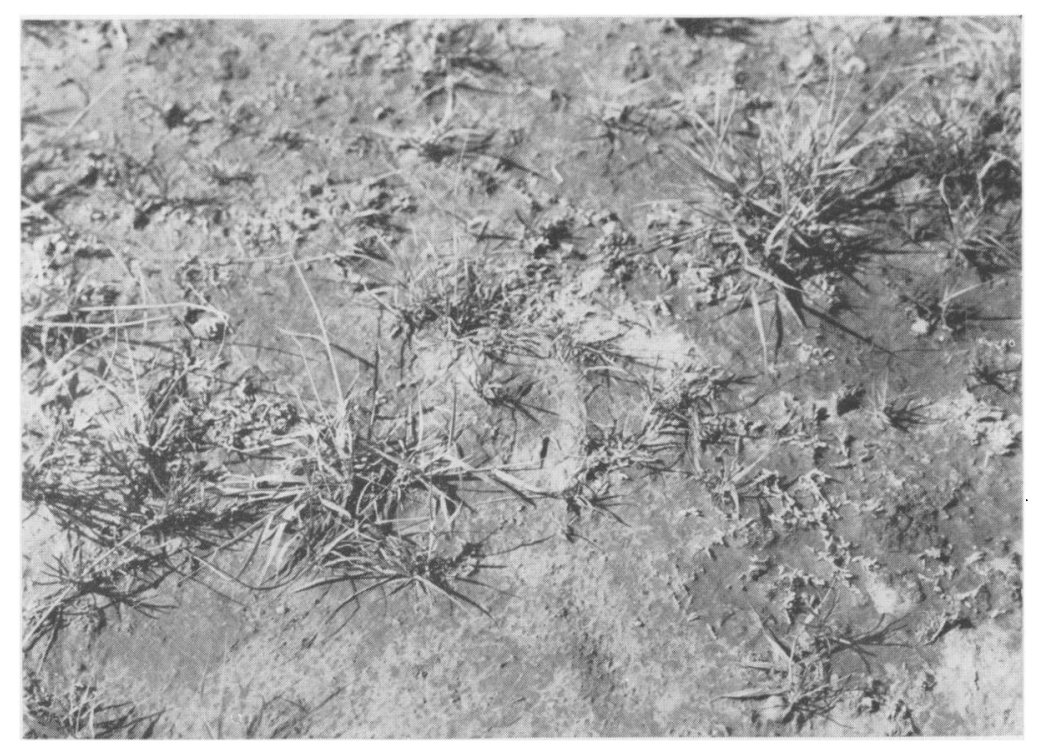

FIG. 45. Detail of remnants of buffalo grass in the open-mat type following the drought. Note the dead plants and the few survivors.

Growth of stolons began in May, 1935, almost immediately following the rains (fig. 46). When they were 6 to 8 inches long, an average daily elongation of .6 inch was observed over a 7-day period very favorable to growth. With the inception of summer drought this decreased to .18 inch, and then to .03 inch on July 13 . By July 20 they began to die back from their tips. Bisects made at various places in the short-grass habitat showed that the roots were both more numerous (5.3 against 2.6) and longer (11.7 against 5.5 inches) at the nodes that had not died than on dead nodes of stolons. The average total root length per live node was 62 inches, that of dead ones 14.3 inches. Counts of large numbers of stolons in both overgrazed and undergrazed areas showed that the latter had 20 per cent more nodes and that 30 per cent more of these were alive.

Bouteloua gracilis made but small gains in the short-grass areas despite the 7 -week period for growth in 1935 , nor were its losses great during the 
following drought. Seasonal variations in basal cover were, however, most extreme in the short-grass type. For example, reduction from 80 to 15 per cent during 1934, increase to 80 per cent by the next midsummer, and a decrease to 25 per cent by fall were recorded in ungrazed prairie.

Data from 49 quadrats in the short-grass type are recorded in table IV. Three ungrazed quadrats in the closed type had a basal cover of 88.3 per cent in 1932. This was slightly reduced in 1934, and the total loss was only 8.6 per cent by the fall of 1935 . Conversely, 3 quadrats in the open type where the basal cover was 36.7 per cent suffered a loss of 77.5 per cent. The great loss occurred between 1932-34. During 1935, the cover increased from 4.9 to 8.3 per cent.

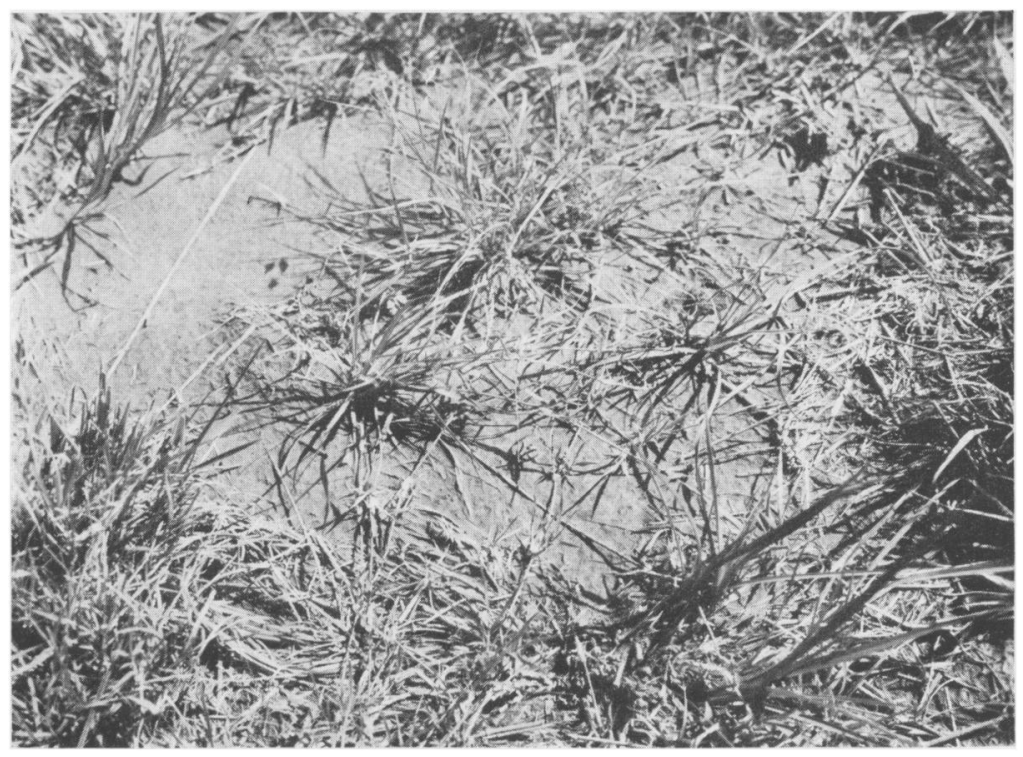

Fig. 46. Bulbilis dactyloides at Hays, Kansas, in June, 1935, reclaiming by spread of stolons areas bared during the drought.

Quadrats in ungrazed short grass, with a basal cover of 23.2 per cent, showed gains of 29.3 per cent. Three moderately grazed quadrats, with 15.1 per cent basal cover in spring, increased in cover to 80 per cent by summer. The cover then decreased to 27.2 per cent by fall, but the seasonal gain was 80.1 per cent. In 13 other moderately grazed quadrats the gains were even greater. The basal cover increased 13.9 per cent which was a percentage gain of 111.2. Thus the moderately grazed quadrats, where the original basal cover was low, made the greater recovery.

In the 24 other quadrats (table IV), the percentage of the unit areas occupied by short grasses only was determined. In seven ungrazed quadrats, located where little bluestem and other grasses were not abundant, short grasses 
TABLE IV. Change in percentage of basal cover in the short-grass type during the drought

\begin{tabular}{|c|c|c|c|c|c|c|c|c|c|}
\hline \multirow[t]{2}{*}{ Habitat } & \multirow{2}{*}{$\begin{array}{l}\text { Num- } \\
\text { ber } \\
\text { of } \\
\text { quad- } \\
\text { rats }\end{array}$} & \multirow[t]{2}{*}{ Treatment } & \multicolumn{3}{|c|}{$\begin{array}{c}\text { Average per cent } \\
\text { basal cover }\end{array}$} & \multicolumn{2}{|c|}{$\begin{array}{l}\text { Per cent } \\
\text { change } \\
\text { basal } \\
\text { cover }\end{array}$} & \multicolumn{2}{|c|}{ Per cent } \\
\hline & & & 1932 & 1934 & 1935 & Gain & Loss & Gain & Loss \\
\hline $\begin{array}{l}\text { Closed type short } \\
\text { grass } \\
\text { Open type short } \\
\text { grass }\end{array}$ & $\begin{array}{l}3 \\
3\end{array}$ & $\begin{array}{l}\text { Ungrazed } \\
\text { Ungrazed }\end{array}$ & $\begin{array}{l}88.3 \\
36.7\end{array}$ & $\begin{array}{r}83.3 \\
4.9\end{array}$ & $\begin{array}{r}80.7 \\
8.3\end{array}$ & - & $\begin{array}{r}7.6 \\
28.4\end{array}$ & - & $\begin{array}{r}8.6 \\
77.5\end{array}$ \\
\hline & & & $\begin{array}{c}\text { Spring } \\
1935\end{array}$ & $\underset{1935}{\text { Summer }}$ & $\begin{array}{l}\text { Fall } \\
1935\end{array}$ & & & & \\
\hline $\begin{array}{l}\text { Short grass } \\
\text { Short grass } \\
\text { Short grass }\end{array}$ & $\begin{array}{l}4 \\
2\end{array}$ & $\begin{array}{l}\text { Ungrazed } \\
\text { Moderately } \\
\text { grazed } \\
\text { Moderately } \\
\text { grazed }\end{array}$ & $\begin{array}{l}23.2 \\
15.1 \\
12.5\end{array}$ & $\begin{array}{r}80.0 \\
-\end{array}$ & $\begin{array}{l}30.0 \\
27.2 \\
26.4\end{array}$ & $\begin{array}{r}6.8 \\
12.1 \\
13.9\end{array}$ & - & \begin{tabular}{|r}
29.3 \\
80.1 \\
111.2
\end{tabular} & - \\
\hline
\end{tabular}

Per cent of square meter occupied by short grasses

\begin{tabular}{l|c|c|c|c|c|c|c|c|c}
\hline & & & 1932 & 1934 & 1935 & & & & \\
\hline $\begin{array}{c}\text { Ecotone between tall } \\
\text { and short grass }\end{array}$ & 7 & Ungrazed & 91.7 & 97.6 & 98.9 & 7.2 & - & 7.8 & - \\
$\begin{array}{c}\text { Ecotone between tall } \\
\text { and short grass }\end{array}$ & 3 & Ungrazed & 33.3 & 48.4 & 53.0 & 19.7 & - & 59.2 & - \\
$\begin{array}{c}\text { Ecotone between tall } \\
\text { and short grass }\end{array}$ & 14 & $\begin{array}{c}\text { Moderately } \\
\text { grazed }\end{array}$ & 65.9 & 84.7 & 94.7 & 28.8 & - & 43.7 & - \\
\hline
\end{tabular}

occupied 91.7 per cent of the quadrat. In the fall of 1935, this increased to 98.9 per cent. In three other ungrazed quadrats, where the short grasses covered only one-third of the soil, they increased, as the little bluestem died, until they occupied 53 per cent of the areas. In 14 moderately grazed quadrats short grasses covered 65.9 per cent of the soil in 1932 and 94.7 per cent in 1935 . The gain was 43.7 per cent. Since half of these quadrats had an initial short-grass cover of 90 per cent in 1932, their possible percentage of gain was small. Hence, the average was materially lowered. Many of the quadrats showed a gain of 50 per cent or more. These data reveal the distinct trend toward an increase of the short grasses in the ecotone as they were partially liberated from competition by death of little bluestem, wire grass, and other taller grasses.

Aristida purpurea became well established in the short-grass habitat during the favorable years preceding the drought. Although furnishing but a small percentage of the basal cover, it was rather uniformly scattered through- 
out. In 11 quadrats charted in the fall of 1932, its average basal cover was 1.08 per cent. It was almost the same ( 1.05 per cent) in 1934 , but decreased to 0.49 per cent by the fall of 1935 . Thus the average percentage of loss was 54.6. Six quadrats, charted in the spring of 1935, contained an average basal cover of Aristida of 5.05 per cent, of which only 1.75 per cent was alive. By the fall of 1935 the living plants had a basal cover of 2.2 per cent. Hence, the average percentage loss from drought was 56.5. Since the first group of quadrats, charted in 1932 and again in 1934, revealed slight losses until again charted in 1935, it is reasonable to assume that most of the loss of wire grass occurred during the extremely dry winter of 1934-35, and that slight gains were made during the early summer of 1935 .

Quadrats in areas covered with dust showed that burial by 0.5 to 1.5 inches of dust often killed the short grasses, but furnished ideal conditions for invasion by weeds.

\section{Big-bluestem type}

The effects of drought had not become apparent on the lowlands characterized by the big-bluestem type by the fall of 1933 . At this time determinations of the percentage of ground cover and the composition of the vegetation were made in three different prairies, all within 5 miles of Hays. These prairies had not been pastured for many years, except perhaps lightly in winter, but mowed for hay in late summer or early fall. The deep alluvial soil is rich and dark in color to a depth of 3 to 6 feet.

Andropogon furcatus constituted about 75 per cent of the vegetation. Bouteloua curtipendula, scattered rather uniformly throughout, Agropyron smithii, confined largely to the bases of the slopes, and Sporobolus asper hookeri in complete possession of a few, small, local areas, added 15 per cent to the grass population. The remaining 10 per cent consisted of 6 minor species of grasses.

The percentage of ground cover, as determined from a number of quadrats in each prairie, varied from 7.7 to 13.7 with an average of 10.8 per cent in 1933. Similar determinations in the same series of quadrats in the fall of 1935 gave 8.3 to 14.7 per cent with an average of 11.7. These results, checked by other detailed study, indicate that no loss in basal cover had been sustained.

The number of square decimeters in which each of the constituent species occurred was also determined in 1933 and again in 1935. Andropogon furcatus and Elymus virginicus showed a definite decrease, the first from 92 to 64 per cent of the square decimeter areas; the second from 8 to 1 per cent. These are in accord with general field estimates which indicated that the bigbluestem constituent of the prairies had decreased from 75 per cent in 1933 to 50 per cent in 1935. Conversely, Bouteloua curtipendula increased its percentage of areas from 19 to 39, Sporobolus asper hookeri from 26 to 39, and Agropyron smithii from 0 to 13 . Certain other grasses gained slightly. The 
forb population remained practically unchanged except that Aster multiflorus made very definite gains along the borders and in the driest areas. In these lowland areas soil moisture was not generally depleted until July, 1935.

\section{The Mixem Prairie at Phillipsburg}

A mixed prairie of about 50 acres lies 12.5 miles south of Phillipsburg, Kansas. It includes much nearly level land and also gentle slopes facing in all directions. In 1933 the bulk of the vegetation consisted of a pure, tallgrass type of about 80 per cent big bluestem and slender grama grass. The big bluestem mostly formed a continuous open sod in which little bluestem was rather poorly represented. About 10 per cent of the area consisted of nearly pure short-grass alternes, mostly blue grama with a small percentage of buffalo grass intermixed or in pure stands. Another 5 to 8 per cent consisted of mixed tall and short grasses. The short grass, whether pure or as an understory, occurred where the topography caused run-off; the bluestems clothed the remainder of the area where run-off was slight.

Aristida purpurea occurred sparingly but scattered plants of Elymus canadensis, Eragrostis pectinacea, and Panicum scribncrianum were common. No wheat grass was found. Forbs were common but none occurred in extensive societies. The most important were Psoralea tenuiflora, Kulmia glutinosa, Solidago mollis, and S. glaberrima, although Opuntia humifusa and Malvastrum coccineum were also common.

Even casual examination in June of 1935 showed that great destruction had been wrought by drought and wind-blown dust. Over the long, north slope especially, new soil, well consolidated by the abundant late spring rains which followed the most severe period of dust storms, lay 0.5 to over 2 inches deep. There were great losses in the buried alternes of blue grama grass and buffalo grass. The deeper the burial, the thinner were the stands of big bluestem. Over extensive areas where the new soil was 2 to 2.5 inches deep and covered with weeds, big bluestem was entirely absent. Elsewhere it was represented by only a few scattered blades. The new growth of some deeply buried clumps had attained a height of 4 to 6 inches and then died. Undoubtedly much destruction had been wrought by drought before the burial by accumulated dust.

The lower joints of many of the cacti were completely buried. Only a few of even the taller prairie forbs persisted. Soil was heaped about the bases of those that grew. The area had been converted into a great waste now well populated with weeds which varied in height from 8 to 18 inches. Chief among these in order of importance were Chenopodium album, Salsola pestifer, Setaria spp., Lepidium virginicum, Helianthus anmus, Amaranthus retroflexus, Solanum rostratum, and Xanthium commune.

On the wind-swept slopes and level lands dust deposit was variable but less pronounced. A layer 0.5 to 1 inch thick was usual. Places recurred 
where the short grasses were dying, but the new growth of buffalo grass was good where not more than 0.25 inch of soil was deposited. The ground cover was far more open than usual. While some of the dead remains were still plain, the general evidence of death of the vegetation was the extent of bare ground. Little bluestem had been killed everywhere; not a single living plant was found. Careful estimates placed the loss of big bluestem at 35 per cent. Many clumps of half-dead Sporobolus cryptandrus were found, while Elymus had greatly decreased. Death did not entirely denude large areas but resulted in greatly thinning the stand. In some places big bluestem had lost half of its holdings. Hence an irregular but continuous pattern of bare ground was the rule. Sometimes destruction of the grass was fairly complete. Over great stretches, however, some good big bluestem still survived.

The degree of destruction was clearly indicated in most places by the abundance of weeds. Their height varied somewhat directly with the depth of deposited soil. The weeds of north slopes also ranged throughout, varying from thinly scattered growths to dense stands.

The upper story of Psoralea tenuiflora was fairly well intact, Gaura coccinea was common, Malvastrum coccineum formed a common ground pattern, and in the ravines the dense growth of Solidago mollis reminded one of the usual buckbrush eastward. Ambrosia artemisiaefolia formed thick growths in a few of the ravines and Aster multiflorus was well developed locally. The understory of Panicum scribnerianum, Antennaria campestris, species of Viola, and even most of Astragalus crassicarpus had disappeared.

A fine level tract of mixed prairie lies near Phillipsburg. It has been studied at intervals for the past 15 years (Weaver, '24). The loess soil is a mellow, dark-brown, fine sandy loam of the Colby series.

The vegetation was typical mixed prairie, the tall grasses alternating with or forming a layer above the shorter ones. Andropogon scoparius, A. furcatus, and Sorghastrum nutans formed more or less continuous sodded areas varying from 6 inches to 7 feet in diameter where short grasses were often almost entirely excluded. Bouteloua curtipendula and Elymus canadensis were other important grasses. Alternating with these were similar or, in drier places, even larger areas of Bulbilis dactyloides and Bouteloua gracilis, intervening areas, often to the extent of one-fourth of the surface being nearly devoid of vegetation. More usually, however, the short and tall grasses were intimately mixed, the latter often showing strong tendencies toward the bunch habit.

In the fall of 1933 it was observed that great injury to the bluestems had resulted from the summer drought. Nearly all of the bunches or mats of sod were partly killed and in many places the entire tops were dead and brown, separating easily from their bases as if decayed. Little bluestem seemed less affected than did big bluestem. Panicum virgatum was green even in the center of patches of big bluestem, probably because of its very deep root system. Bouteloua gracilis and B. hirsuta were both rapidly producing flower 
stalks after the cessation of drought. Aristida purpurea had seeded at about the normal height. $B$. curtipendula had been injured considerably by the drought. The brown patches of the tall grasses showed conspicuously against the green pattern of the shorter ones and indicated clearly what would happen should drought years continue.

Further study in the midsummer of 1935 showed that the tall grasses had practically all succumbed to the continued drought. This prairie had escaped any burial by dust. A living little bluestem was not found although the dead bases were plentiful. Big bluestem had likewise disappeared except in the depression of an old road. Sorghastrum mutans had died, Elymus canadensis was found only in the road, and only mere relicts of Bouteloua curtipendula were seen. Even many plants of Opuntia humifusa had died. Thus the once well developed upper story of tall grasses had disappeared except for a very scattered growth of Sporobolus cryptandrus and Aristida purpurea.

The short grass vegetation was in a thiriving condition and blossoming profusely. This resulted from the abundant rainfall which was no longer shared by the tall-grass layer, nor were these short grasses handicapped by shading. The long stolons of Bulbilis were spreading rapidly over the dead clumps of tall grasses. Many bared areas were already half sodded by the abundant tuft-producing stolons. Blue grama grass was also increasing its territory by filling in the bunches with new stems, by spreading slightly by tillers, and also by the production of seedlings. The foliage cover of these grasses had increased greatly by the spreading of the tops over portions of the adjacent bare areas. The average foliage cover was not more than about 60 per cent, and only 40 per cent where the tall grasses were best developed. But in the local patches of short grasses it was 80 to 100 per cent. The basal cover had been reduced in proportion to the death of the tall grasses except for such gains as were made by the spreading of the short grasses.

Weeds were few; most of the bared spaces still remained free of invaders. Festuca octoflora and Hordeum pusillum occurred sparingly in bunches. Lepidium virginicum was scattered over the bared places as were also some Salsola pestifer and Setaria viridis. Seedlings of the cacti were common. Forbs were not greatly in evidence; none had become weedy nor made noticeable gains.

By September drought had killed most of the new growth of buffalo grass. Annual weeds, as on the preceding prairie, were very abundant.

\section{Groups of Mixed Prairies}

Thirty-one areas of grassland extending across west-central Kansas, were studied, some at two or more periods, between October, 1934, and the fall of 1935, for the purpose of determining losses due to drought. Percentage of ground cover was compared with the normal cover as based upon previous examination and comparisons with similar prairies at Hays. Because of 
local distribution of rains during the drought, the results may be conveniently presented by placing the prairies into three groups. In each group, ungrazed, moderately grazed, and heavily grazed prairies were studied (fig. 47).

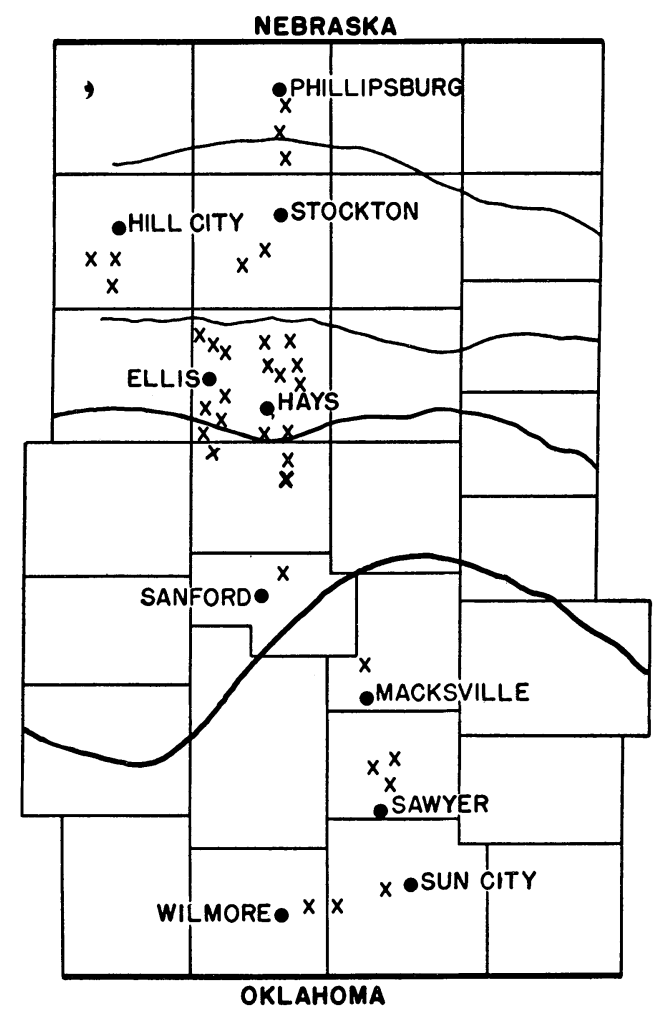

FIG. 47. Location of grassland areas studied in the mixed prairie of west-central Kansas. Phillipsburg is 65 miles due west of Montrose, Kansas (fig. 2), which was the most westerly station studied in the tall-grass prairie.

\section{Prairies south of Hays}

Twelve prairies 8 to 116 miles south and southeast of the base station were studied. The soil varied from a heavy clay loam to light sandy loam. Bulbilis dactyloides and Bouteloua gracilis were the chief grasses on the heavier soil types, the former appearing to survive better than the blue grama where grazing was heaviest. Where rains fell on a considerably reduced ground cover, stolons of buffalo grass spread rapidly. On lighter soil types, buffalo grass was rare, and rather large, distinct bunches of blue grama grass occurred. Soil around the bunches had been gradually removed by the wind, leaving the plants on small mounds. Thus exposed the soil rapidly dried and large dead clumps were common. On rough land, where grazing 
had not been too severe, little and big bluestem were dominant, but on similar heavily grazed areas they had disappeared.

Drought had been less severe than either north or west of Hays. This was clearly shown not only by smaller losses among prairie plants but also by the better growth of winter wheat. It was also indicated by the presence of Antennaria campestris, Festuca octoflora, and certain other species not found elsewhere. The short grasses began to grow in April, and many of the stolons were alive, a phenomenon not found elsewhere in this Kansas area. A heavy growth of little bluestem had resulted from the wet years preceding 1933. Here, losses were especially great during the drought.

Loss of ground cover varied from 30 per cent on moderately grazed prairies to 74 per cent on some heavily grazed. An average loss of 36 per cent from six moderately grazed prairies was determined. These prairies had a development of plant cover which did not use water in excess but furnished adequate protection to the soil against desiccation by wind.

Losses in five heavily grazed prairies ranged from 47 to 87 per cent with an average of 74 . Losses in some cases were greatly accelerated by severe trampling as the hungry cattle wandered about. In these heavily grazed areas there was a considerable increase of the following prairie forbs: Plantago purshii, P. spinulosa, Diaperia prolifera, Lappula texana, Cryptantha crassisepala, Artemisia sp., and Antennaria campestris.

\section{Prairies north of Hays}

Eight prairies lying 12 to 62 miles north of Hays were examined, mostly at two or three different periods. The soil of the rolling to hilly topography varied in texture from sandy loam to clay loam. Short grasses dominated in grazed areas except on rough land near streams characterized by limestone outcrops, where little bluestem was usually dominant.

Loss of ground cover ranged from 50 per cent on one ungrazed area to 98 per cent on heavily grazed ones. The lower portions of the area, ungrazed for many years, had been rather continuously cut for hay. The greatest losses occurred where the vegetation had grown most luxuriantly on the upland during the wet period before the drought. On the highest portions of the prairie, dead crowns of Andropogon scoparius, 3 to 14 inches in diameter, were found. Farther down the slopes and on lowlands relatively slight losses had occurred. Thus the great losses on the higher ground largely account for the high average loss.

Three moderately grazed prairies presented an average loss of 54 per cent. Two were primarily short-grass areas where the ground cover was reduced by drought to 60 and 70 per cent, respectively. The third, dominated by little bluestem, suffered a loss of only 43 per cent.

The heavily grazed prairies, on rough limestone outcrops covered by the little-bluestem type, suffered most severely on the south exposures. Here the 
cover of grass was often reduced to less than 1 per cent. The following forbs constituted nearly all of the remainder of the vegetation: Gutierrezia sarothrae, Leucelene cricoides, Comandra pallida, Echinacea pallida, and Lesquerella ovalifolia. North-facing slopes were also greatly overgrazed but the ravages of drought were less marked.

Vegetation on sandy land, where heavily grazed, suffered very severely from drought, losses often amounting to 95 or even 100 per cent. Native grasses were commonly replaced by Gaillardia pulchella, Helianthus petiolaris, Croton texensis, Setaria viridis, Psoralea lanceolata, and Salsola pestifer.

The short-grass cover of buffalo grass and blue grama on the heavytextured upland soils often sustained losses of 95 to 98 per cent under heavy grazing. During the moist early summer of 1935 the stolons of buffalo grass grew rapidly and covered many bared areas. They failed, however, to survive the hot, dry portion of the summer and consequently died back, leaving the same meager cover found in the spring.

\section{Prairies west of Hays}

Seven prairies 15 to 56 miles northwest of the base station, and four approximately 20 miles southwest were repeatedly examined. The soils varied in texture from the heavy loams of uplands where short grasses prevail to the sandy loam commonly found near the Smoky Hill River. They also included limestone outcrops where little bluestem was prevalent. This group of prairies sustained the greatest average loss of all-84 per cent, ranging from 70 per cent on an area moderately grazed to 96 per cent on a similar one heavily grazed. In heavily grazed pastures the cattle had not only eaten practically every vestige of green but also in desperation had gnawed into the crowns and roots of the grasses devouring them with the attached soil. The dried dung, unlike that resulting from normal herbage, was heavy, since it incorporated quantities of soil. Such extreme signs of overgrazing and drought were rather general.

The only ungrazed prairie found had developed such an excellent cover during years of good rainfall that the reduction of 14 inches in the annual rainfall decreased soil moisture to a point where the demands of the growing vegetation could not be met. The result was the death of the vegetation over large areas and an average loss of 85 per cent. An adjoining, moderately grazed area used the water more conservatively and maintained a considerably higher living basal cover. This was the usual condition; moderately grazed areas suffered less. In these prairies the average loss was 72 per cent. This high loss resulted from increased intensity of drought west of Hays.

The soil was almost bare on heavily grazed prairies. Over many square meters not a living forb or blade of grass could be found. The average loss in this group was 91 per cent in the spring of 1935 and remained thus until 
after the late summer rains. Then considerable growth occurred. By December, buffalo grass had spread widlely, thus illustrating the wonderful recuperative powers of the vegetation after three years of drought.

Losses in the little-bluestem type were slightly less. Here some bunches were so favorably rooted in the deep, moist soil of crevices and pockets of the limestone that they lingered on despite the drought.

The sandy soil was clothed with mixed tall and short grasses of which Andropogon scoparius, Sporobolus cryptandrus, Bouteloua curtipendula, and $B$. gracilis were most important. The plants commonly occurred in bunches or mats with much bare soil between. Heavy grazing and drought had resulted in the death of most of these. In many places the dead crowns remained intact (fig. 48).

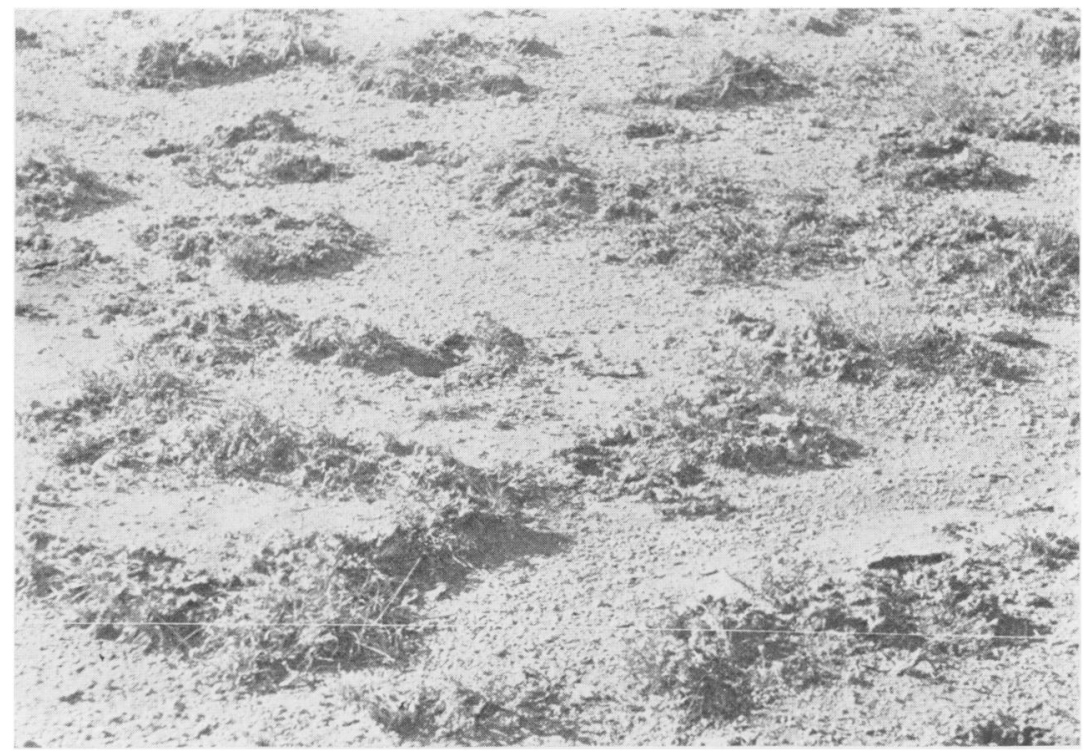

FIG. 48. Pasture 50 miles west of Hays, Kansas, in fall of 1935 . The dead remnants of the bunches of little bluestem are all that remain of the plant cover.

A summary of the losses in the 31 prairies studied, together with the type of treatment, is given in table $\mathrm{V}$.

Where the prairies were located near cultivated fields, a layer of dust 0.5 to 4 inches in depth commonly covered the vegetation. The depth often varied directly with the density of the plant cover, being greatest where it was heavy. In many places where weeds had blown into the fences and formed a barrier to wind-blown dust, great drifts accumulated over the fences and extended outward over the grassland (fig. 49). Where the new deposit was more than an inch in thickness, loss of vegetation was practically complete. Farther out in the prairie, deep drifts of dust accumulated over the 
TABLE V. Loss in plant cover in various types of Kansas prairies under different treatments

\begin{tabular}{|c|c|c|c|c|c|}
\hline Type of prairie & No. & $\begin{array}{c}\text { Direction from } \\
\text { Hays }\end{array}$ & Treatment & $\begin{array}{l}\text { Per cent } \\
\text { loss }\end{array}$ & $\begin{array}{l}\text { Ave. } \\
\text { per cent }\end{array}$ \\
\hline Little bluestem & 1 & $110 \mathrm{mi} . \mathrm{S}$. & Ungrazed & 60 & 60 \\
\hline $\begin{array}{l}\text { Little bluestem } \\
\text { Mixed } \\
\text { Short grass }\end{array}$ & $\begin{array}{l}1 \\
2 \\
3\end{array}$ & $\begin{array}{l}115 \mathrm{mi} . \mathrm{S} . \\
98 \mathrm{mi} . \mathrm{S} . \\
15-100 \mathrm{mi} . \mathrm{S} .\end{array}$ & $\begin{array}{c}\text { Moderately grazed } \\
\text { ،، }\end{array}$ & $\begin{array}{l}30 \\
35 \\
44\end{array}$ & 36 \\
\hline Short grass & 5 & 8-116 mi. S. & Heavily grazed & 74 & 74 \\
\hline Little bluestem & 1 & $14 \mathrm{mi} . \mathrm{N}$. & Ungrazed & 50 & 50 \\
\hline $\begin{array}{l}\text { Little bluestem } \\
\text { Short grass }\end{array}$ & $\begin{array}{l}1 \\
2\end{array}$ & $\begin{array}{l}15 \mathrm{mi} . \mathrm{N} . \\
12-61 \mathrm{mi} . \mathrm{N} .\end{array}$ & Moderately grazed & $\begin{array}{l}43 \\
65\end{array}$ & 54 \\
\hline $\begin{array}{l}\text { Little bluestem } \\
\text { Mixed } \\
\text { Short grass }\end{array}$ & $\begin{array}{l}2 \\
1 \\
1\end{array}$ & $\begin{array}{l}16-61 \mathrm{mi} . \mathrm{N} . \\
18 \mathrm{mi} . \mathrm{N} . \\
62 \mathrm{mi} . \mathrm{N} .\end{array}$ & $\begin{array}{c}\text { Heavily grazed } \\
\text { “، } \\
\text { ، }\end{array}$ & $\begin{array}{l}90 \\
96 \\
88\end{array}$ & 91 \\
\hline Little bluestem & 1 & $50 \mathrm{mi}$. N.W. & Ungrazed & 85 & 85 \\
\hline $\begin{array}{l}\text { Little bluestem } \\
\text { Short grass }\end{array}$ & $\begin{array}{l}1 \\
2\end{array}$ & $\begin{array}{l}56 \text { mi. N.W. } \\
18-30 \mathrm{mi} . \mathrm{N} . \mathrm{W} .\end{array}$ & Moderately grazed & $\begin{array}{l}70 \\
75\end{array}$ & 72 \\
\hline $\begin{array}{l}\text { Little bluestem } \\
\text { Mixed } \\
\text { Short grass }\end{array}$ & $\begin{array}{l}2 \\
1 \\
4\end{array}$ & $\begin{array}{l}22-25 \text { mi. N.W. } \\
55 \text { mi. N.W. } \\
15-25 \text { mi. S.W. }\end{array}$ & $\begin{array}{c}\text { Heavily grazed } \\
\text { “، } \\
\text { “" }\end{array}$ & $\begin{array}{l}89 \\
95 \\
99\end{array}$ & 91 \\
\hline
\end{tabular}

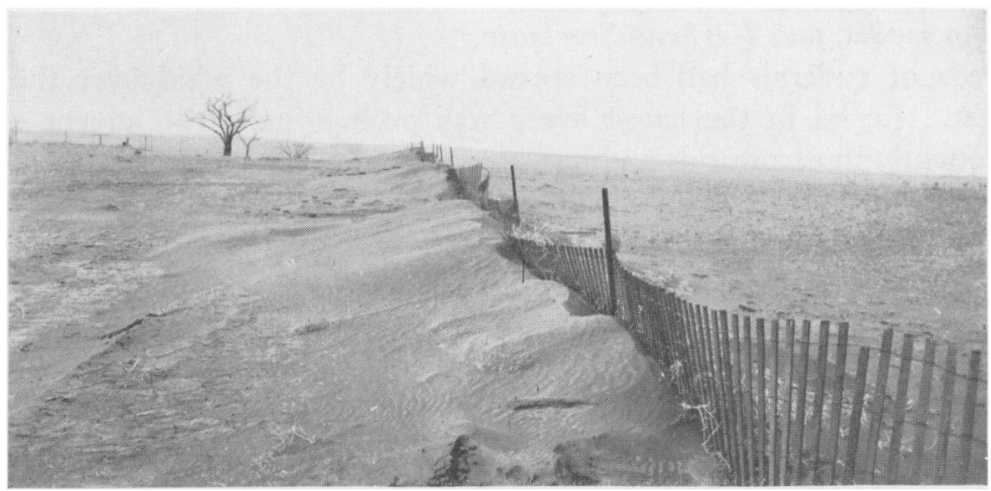

FIG. 49. Wind-blown dust caught by snow fence in west-central Kansas. Photo by G. E. Condra, April 1935.

bunches of grass, which resulted in their death. Where the ground was nearly bare and the living portions of the grass remnants were below or just above the surface of the soil, the layer of dust was comparatively thin and losses caused directly by it were usually small.

Dust, even from distant fields, carried with it myriads of seeds of the weeds common to cultivated land. Seeds of Russian thistle, tickle grass, etc., 
scattered far by plants tumbling before the wind, were even more widely distributed during the "black blizzards."

\section{Changes in Populations of Grasses and Forbs}

Certain grasses, found regularly in the prairies of midwestern Kansas during preceding years, were so adversely affected by the drought that during 1934-35 they were found only occasionally. Chief among these were Eatonia obtusata, Koeleria cristata, Poa arida, Panicum scribnerianum, Aristida purpurea, Festuca octoflora, and Alopecurus geniculatus.

The following forbs, although not affected to the same extent by the drought, were either partially or completely eliminated from the prairies: Achillea lanulosa, Ambrosia psilostachya, Anemone caroliniana, Antennaria campestris, Astragalus missouriensis, Astragalus shortianus, Castilleja sessiliflora, Cerastium brachypodum, Erigeron ramosus, Myosurus minimus, Oxytropis lambertii, Polygala alba, Psoralea argophylla, Sophora sericea, Specularia leptocarpa, Specularia perfoliata, Spermolepis divaricata, Tithymalus missouriensis, and Viola rafinesquii.

The decrease in ground cover occasioned by the death of the grasses and forbs resulted in an increase in the numbers of certain native forbs of greater drought resistance. Those that spread most conspicuously were as follows: Artemisia spp., Aster multiflorus, Diaperia prolifera, Echinacea pallida, Gutierrezia sarothrae, Malvastrum coccineum, Oxalis stricta, Plantago purshii, Plantago pusilla, Plantago spinulosa, Polygala verticillata, Quincula lobata, Solidago mollis, and Verbena bracteosa.

Seeds of ruderals had been spread widely by the wind over the whole midwest. Ecesis in the bared areas was prompt upon the advent of rain. Consequently most prairies and pastures were literally covered with seedlings of species of Chenopodium and Amaranthus, Eragrostis major, Panicum capillare, Setaria viridis, Solanum rostratum, Lepidium virginicum, Salsola pestifer, Bromus tectorum, and Hordeum pusillum.

So abundant were the weeds, that the prairies often appeared more like abandoned fields than grassland. The tallest weeds had rather completely covered the ground, but the summer drought of 1935 had killed most of them before they were fully grown. The most conspicuous species were Salsola pestifer and Solanum rostratum. Eragrostis major and Panicum capillare often formed a larger percentage of the ground cover than did the native short grasses. In sandy soil the weed population was fully developed. Large areas were often completely occupied by Helianthus annuus, Chenopodium album, C. lanceolatum, C. leptophyllum, Amaranthus retroflexus, Solanum rostratum, and Salsola pestifer.

\section{SUMMARY}

Following the most severe drought ever recorded in the prairies of Iowa, Nebraska, and Kansas, studies were made to determine the effects upon the vegetation. 
The 30 or more prairies examined in Iowa, Nebraska, and east-central Kansas had each been fully studied before the drought so that changes were readily determined. Prairies on the deep loess soil of southwestern Iowa as well as some northeastward on the glacial soils had not been harmed. Others had suffered a loss of 20 to 50 per cent of certain grasses on the most exposed slopes.

Death by drought increased southwestward, varying from 20 to 50 per cent on thinner soils of exposed ridges to 80 to 95 per cent losses on nearly level areas farther west. Great destruction also occurred even on low ground, sometimes resulting in an entire change in plant populations even in eastern Nebraska.

All of the native grasses suffered some loss, but death was greater among those with relatively shorter roots: Andropogon scoparius, Koeleria cristata, Stipa spartea, and the invading Poa pratensis. This often occurred everywhere but especially where they occupied the drier soils. Sporobolus heterolepis also sustained losses which, like those of Sorghastrum nutans, of ten amounted to 80 or more per cent. Andropogon furcatus, because of its deeper root system, was usually injured least.

Losses among interstitial, low grasses and forbs were often practically complete after the protecting cover of tall grasses dried.

Invasion by the drought-resisting and rapidly spreading Agropyron smithii was rapid and locally complete. It occurred widely. Bulbilis dactyloides and Festuca octoflora were other native grasses that increased greatly, especially westward.

Among native forbs that spread most widely, when death of the dominants decreased competition, were Aster multiflorus, Erigeron ramosus, Silene antirrhina, and Specularia perfoliata.

Certain ruderals, normally not found in prairies, were widely distributed. The most conspicuous were Lepidium virginicum, Leptilon canadense, Bromus secalinus, and Tragopogon pratensis.

Severity of drought in the mixed prairie was studied intensively at Hays, and from the Nebraska to the Oklahoma border in west-central Kansas.

The drought years of 1933 to 1935, when the mean annual precipitation was only 15.4 inches, were preceded by 6 years with an average precipitation 4.9 inches above the normal (22.8 in.). Scores of permanent chart quadrats were marked out, many before the beginning of the drought.

Water content of soil was exhausted to or almost to the depth of root penetration (3.5 to $6 \mathrm{ft}$.) of the dominant grasses. This occurred at a time when the average day temperatures were $86^{\circ}$ to $97^{\circ} \mathrm{F}$. and relative humidity was very low. The severe conditions were aggravated by high winds and often by dust storms.

Andropogon scoparius suffered losses of 90 to 100 per cent where it was intermixed with the short grasses. In its typical consocies, losses of 50 to 87 per cent occurred where it was ungrazed and 66 to 96 per cent under 
moderate grazing. Moderate grazing preceding the drought, reduced the density of the cover and enabled the vegetation to survive longer on the remaining soil moisture. Boutelona curtipendula and Andropogon furcaius, both intermixed with but rooted more deeply than $A$. scoparius, although at first suffering losses, increased with temporary conditions favorable to growth and partially replaced little bluestem.

The closed type of Bulbilis-Bouteloua showed relatively small losses when protected from grazing, although certain native forbs entirely disappeared. Losses in open, ungrazed short grass were 70 to 80 per cent. In both types, stolons of Bulbilis dactyloides rapidly reclaimed bare areas when moisture was available for growth. Gains of 30 to 111 per cent in basal cover over that of 1932 were recorded in the fall of 1935 . There was a marked tendency for this grass to reclaim areas bared by the death of the taller grasses.

At Phillipsburg the mixed prairie was temporarily converted into pure short grass by the death of the bluestems and other tall grasses. Other prairies were buried by dust and converted into waste areas populated by weeds.

Ungrazed prairies of south-central Kansas lost 60 per cent of the basal cover; various types moderately grazed, 36 per cent; and others heavily grazed, 74 per cent. Losses in the same sequence in north-central Kansas were 50, 54, and 91 per cent, respectively.

Conditions were most severe in the west-central part where ungrazed prairies lost 85 per cent, moderately grazed areas 72 per cent, and heavily grazed ones 91 per cent.

Deficient soil moisture, coupled with extremely high temperatures and low humidities, and supplemented by wind and burial by dust, was the cause of the destruction.

Lists of native grasses that entirely or almost entirely disappeared, and native forbs that increased in abundance are given. Weeds sowed widely by the wind and growing in such abundance as to give native grassland the appearance of abandoned fields are also listed.

\section{Literature Cited}

Clements, F. E. 1920. Plant indicators. Carn. Inst. Wash. Publ. 290.

- 1935. Plant succession and human problems. Carn. Inst. Wash. News Serv. Bull. 3(30/31):

- and J. E. Weaver. 1924. Experimental vegetation. Carn. Inst. Wash. Publ. 355 .

Nedrow, W. W. 1937. Studies on the physiology and ecology of roots. Ecology 18:

Noll, W. C. 1935. Comparison of the environment and some physiological responses of prairie vegetation and winter wheat during a year of extreme drought. Manuscript.

Savage, D. A. 1934. Methods of reestablishing buffalo grass on cultivated land in the Great Plains. U. S. Dept. Agri. Circ. 328. 
- 1935. "They came through"- Survey shows where drought met most resistance. Soil Conservation 1(2): 4-5.

Thornber, J. J. 1901. The prairie-grass formation in region I. Rep. Bot. Surv. Nebr. 5: 29-143.

Weaver, J. E. 1924. Plant production as a measure of environment. Jour. Ecol. 12: 205-237.

- and A. F. Thiel. 1917. Ecological studies in the tension zone between prairie and woodland. Bot. Surv. Nebr. New ser. 1:3-60.

- and T. J. Fitzpatrick. 1932. Ecology and relative importance of the dominants of tall-grass prairie. Bot. Gaz. 93: 113-150.

— 1934. The prairie. Ecol. Monog. 4: 110-295.

- - L. A. Stoddart, and W. Noll. 1935. Response of the prairie to the great drought of 1934. Ecology 16: 612-629. 